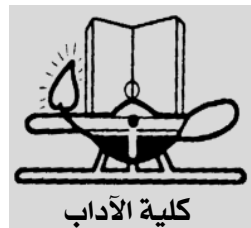

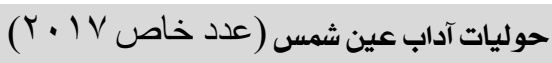
www.aafu.journals.ekb.eg//:http

(دورية علمية محكمةة)

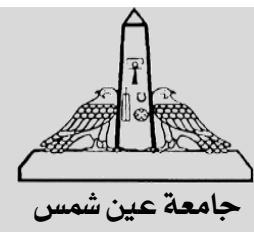

\title{
هفهوم النسق في النقد والدراسات الثقافية
}

* محمد السنوسي عمر التواتي

طالب دكتور اه - قسم اللغة العربية و آدابها- كلية الآداب - جامعة عين شس

مفهوم النسق واحد من المفاهيم الرئيسية التي اعتمد عليها النقد الثقافي في تحليله

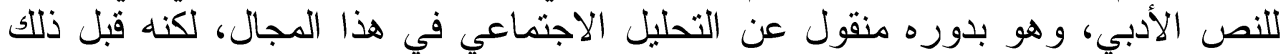

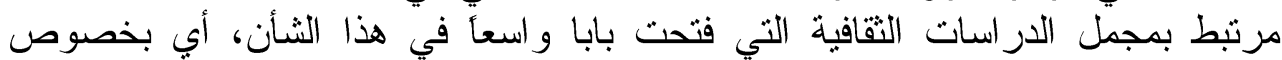

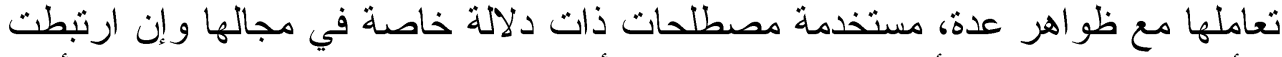

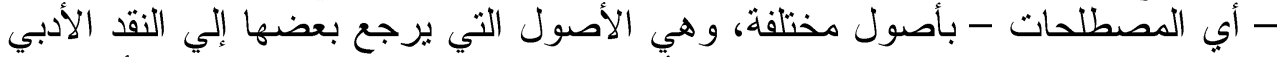

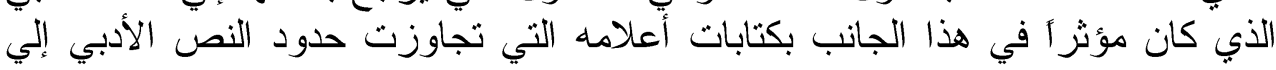

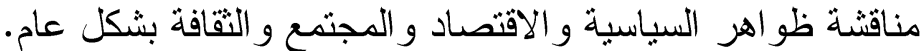
وفيما يتعلق بالنص الأدبي خاصة، فإن الملحوظة الأبرز في شأنه تتعلق بالتداخل

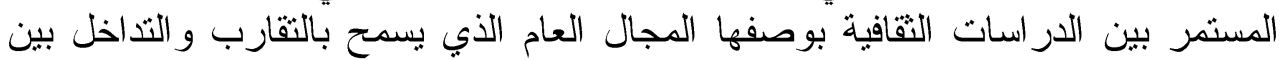
كل هذه الاختصاصات في جانب، والنقا الأدبي بوصفه أحد المصادر الأساسية المؤثرة

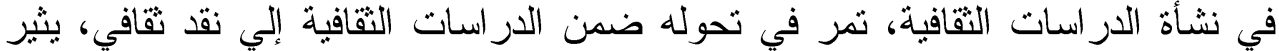

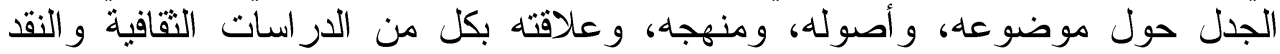

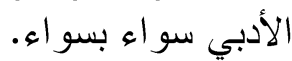

و أمام عدم وضوح مفهوم النسق ذاته في ثللك الكتابات على الرغم من حديثها

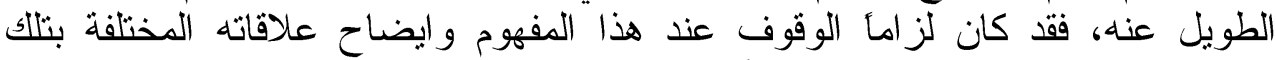
المصادر المؤسسة في تعبينه، من أجل الوقوف لون على طبيعة وجوده و آثار تجلياته في و على هذا الأساس تتاولت مفهوم النسق في ضوء الأه علاقته بالنقدين الثقافي و الأدبي، كم في علاقته بأصول هذين الر افدين في الدر اسات الثقافية. 
مفهوم النسق واحد من المفاهيم الرئيسية التى اعتمد علبها النقد الثقافي فى تحليله

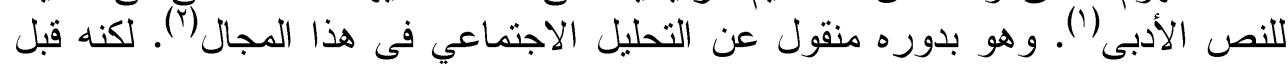

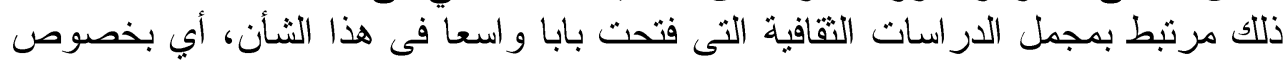

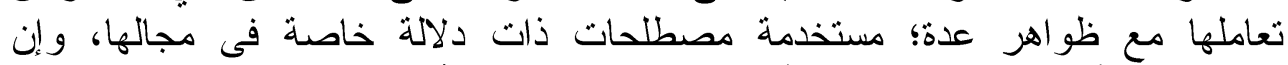

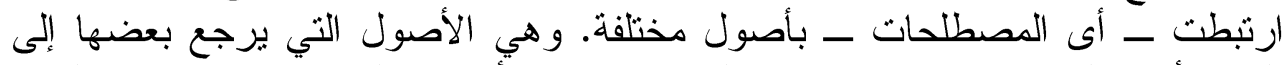

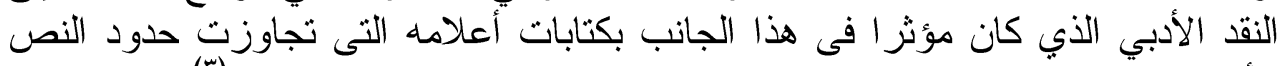

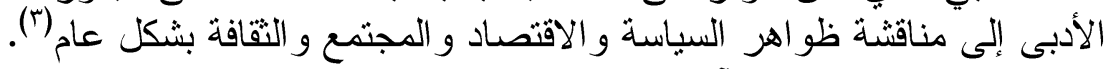

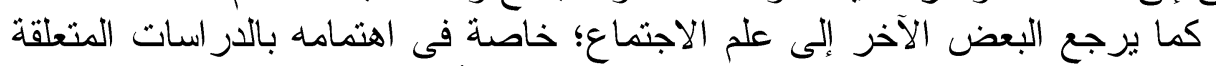

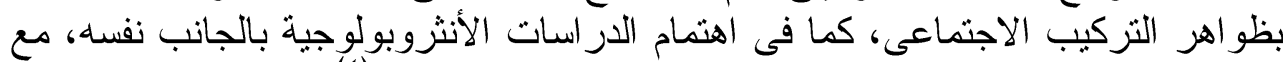

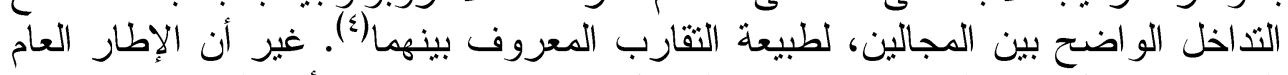

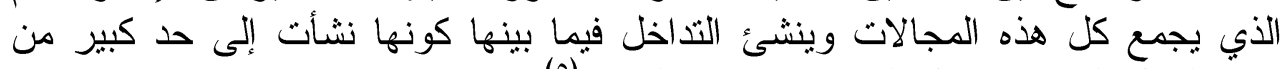

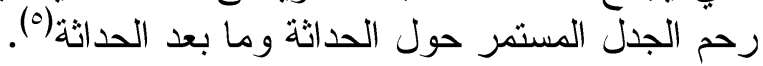

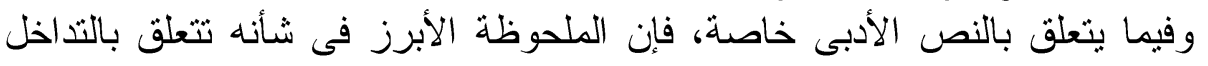

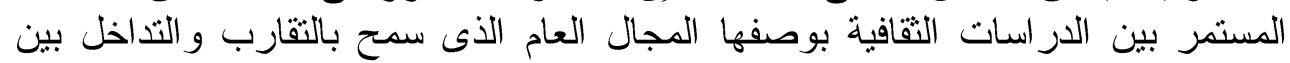

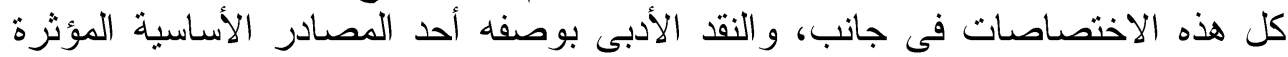

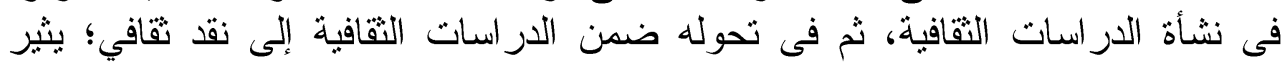

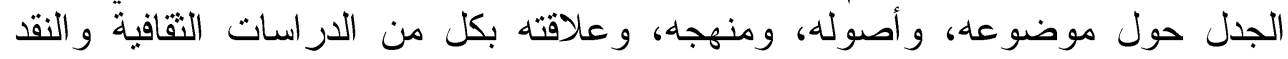

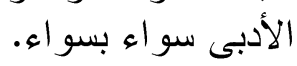

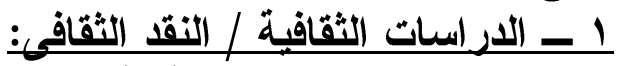

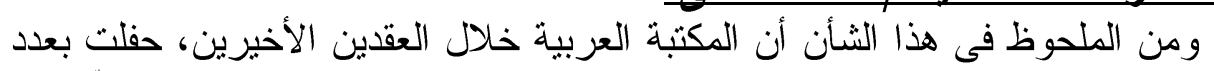

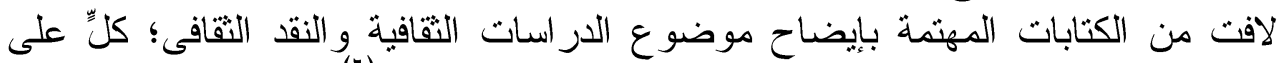

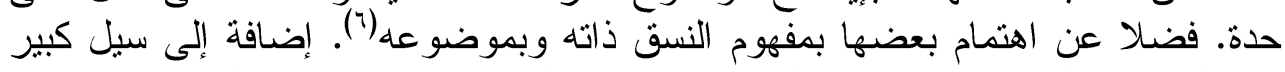
من الكتابات المهتمة بموضوع الحداثة وما بعد الحداثة فى جانب، وضئ والثقافة فى جلى جانب

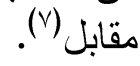

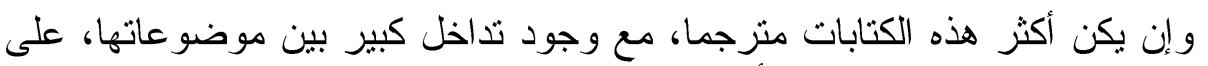

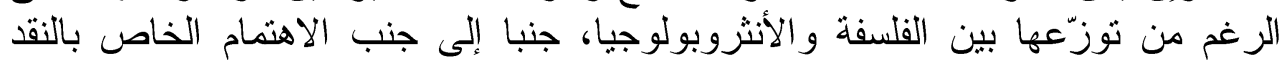

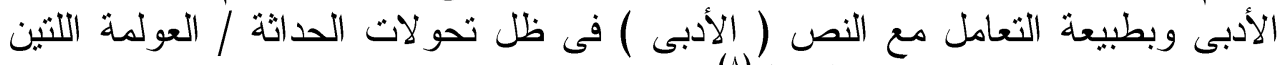

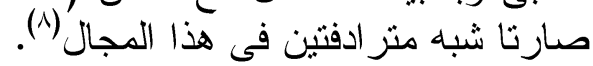

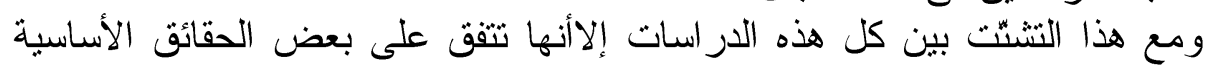

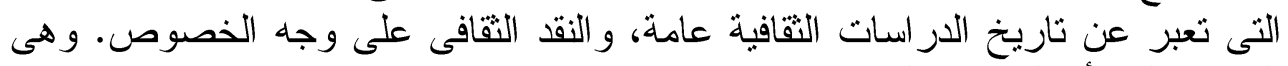

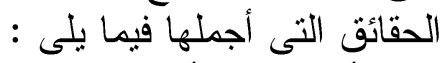

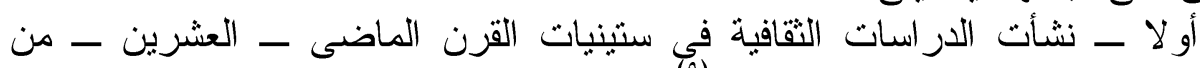

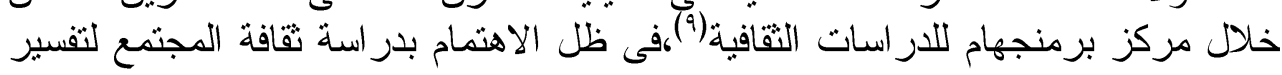

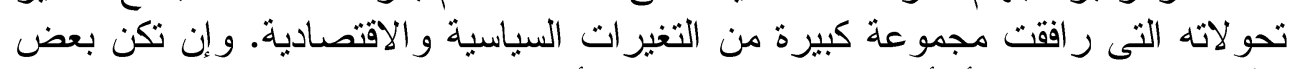

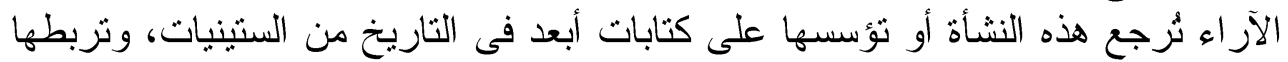

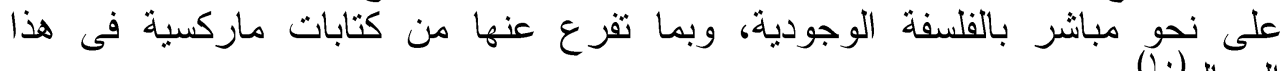
ثانبا - ـ وأهم الظو اهر التى ركزت على در استها هذه الكتابات الناشئة تحث اسم الدراسات الثقافية، ذلك الاختلاف البيّن بين ثقافات الشعوب، خاصة النامية منها أو الثئ 


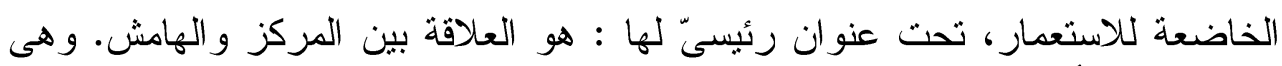

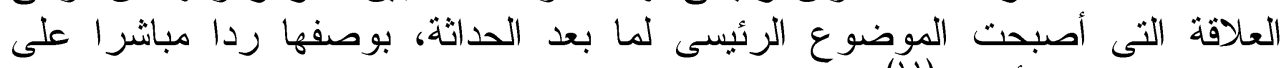

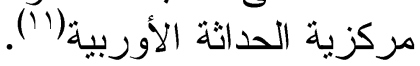

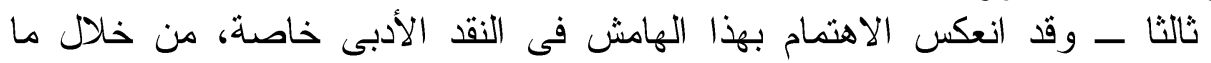

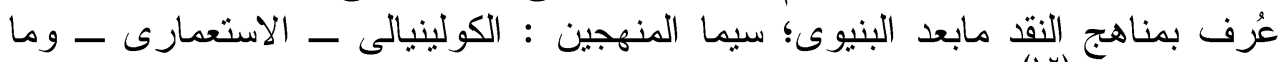

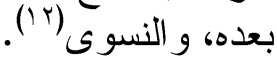
غير أن دراسات الهامش نفسها توسّعت لتشمل أيضا ثقافة الأقليات، أو تلألك الفئات

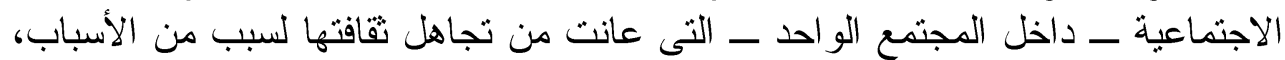

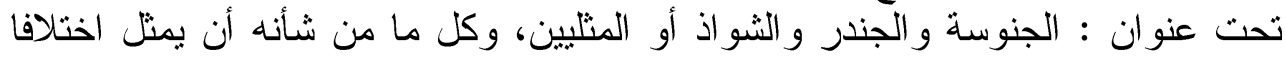

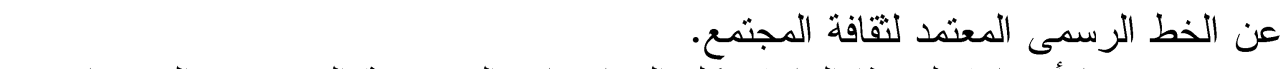

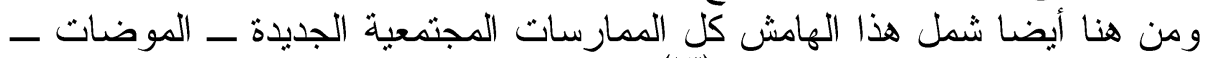

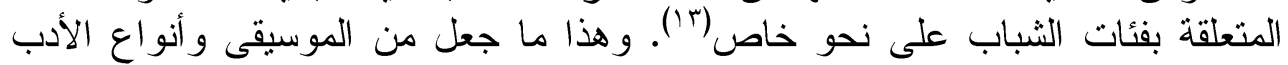

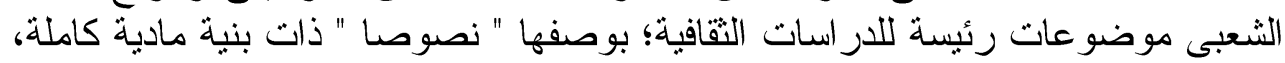

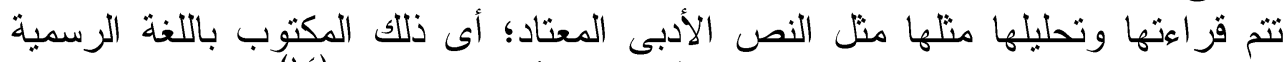

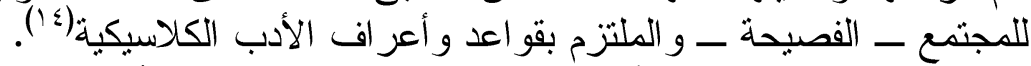

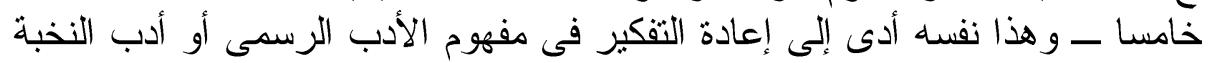

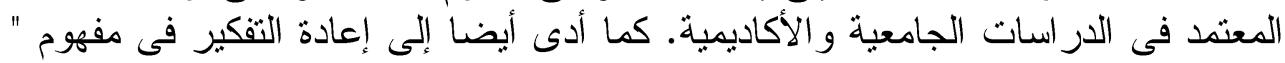

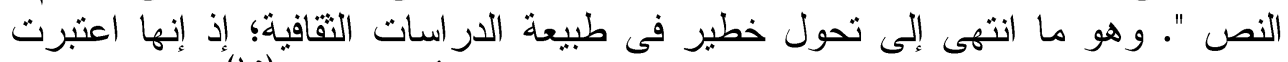

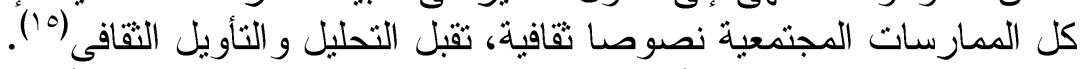

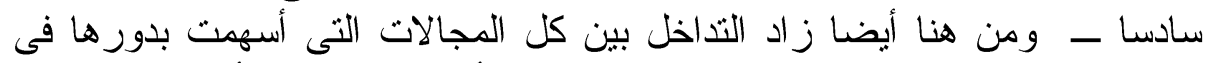

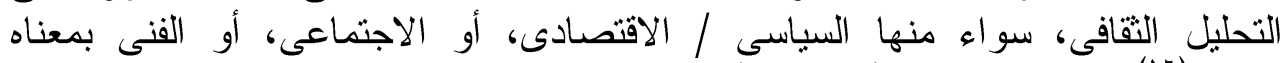

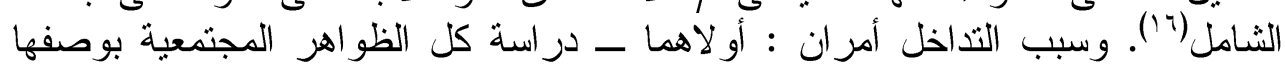

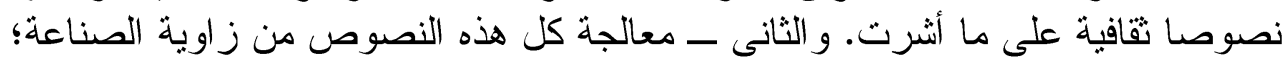

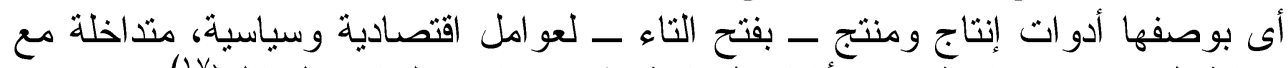

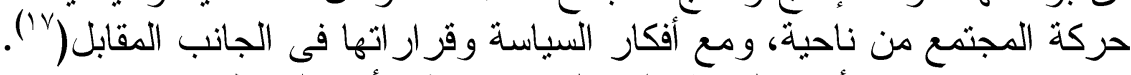

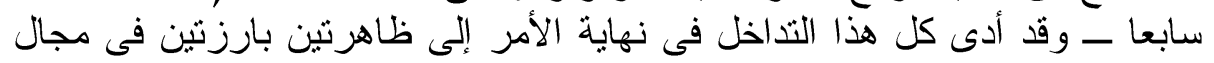

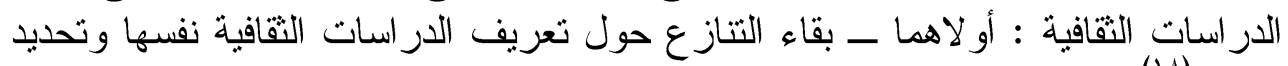

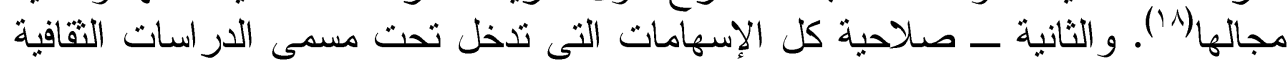

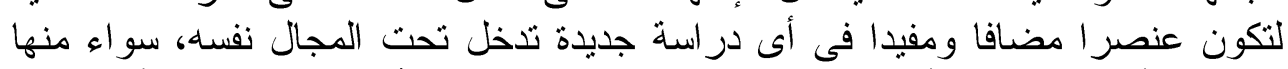

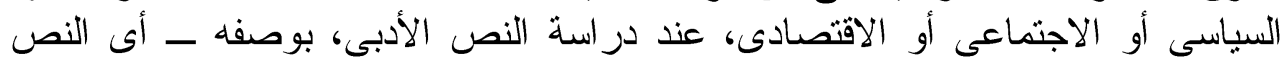

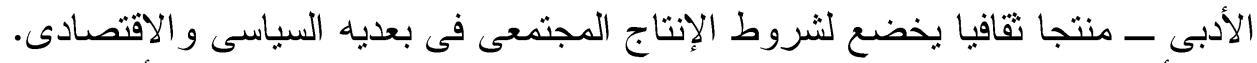

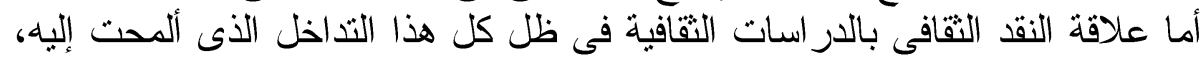

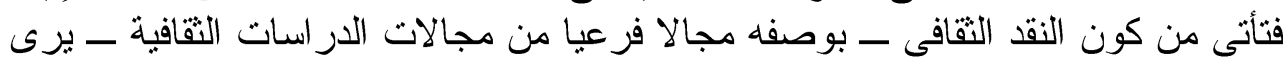

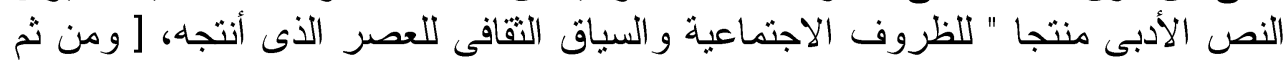

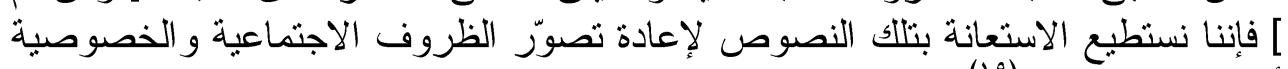
أو الأسياق الثقافيعى" (19).

وليس المقصود بهذا أن النص يُعامل كما كان فى المناهج التاريخية بوصفه وثثقة

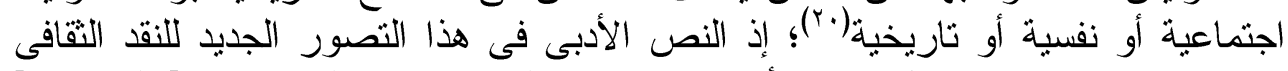

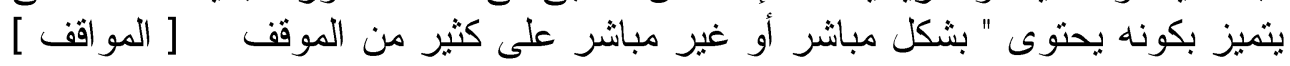




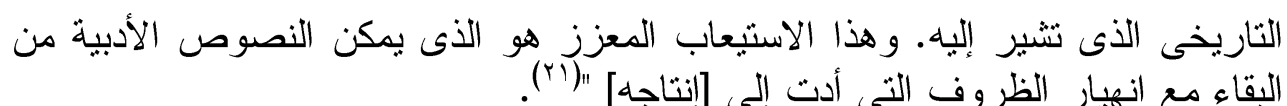

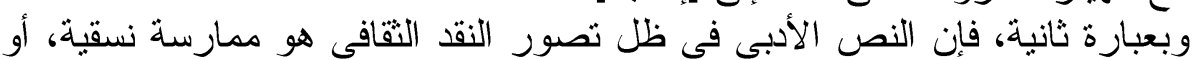

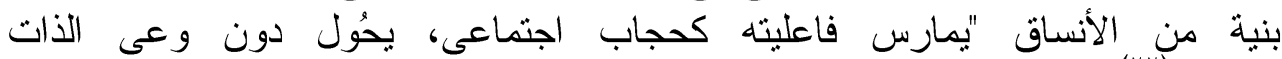

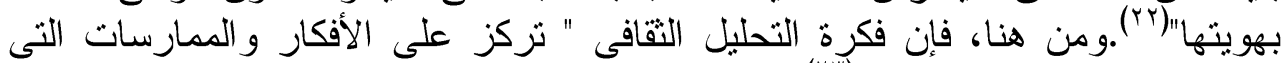

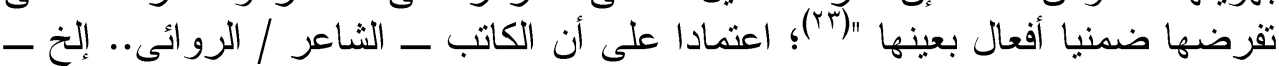

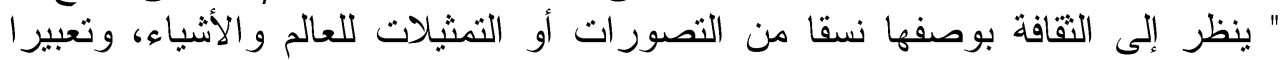

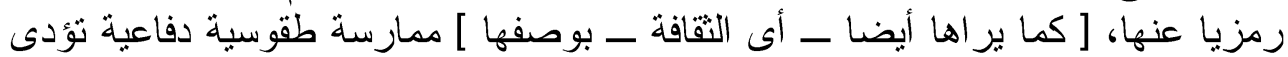

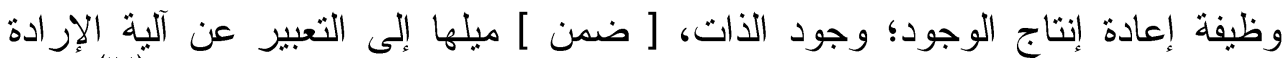

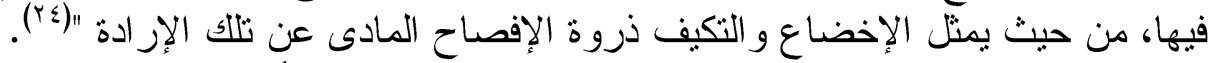

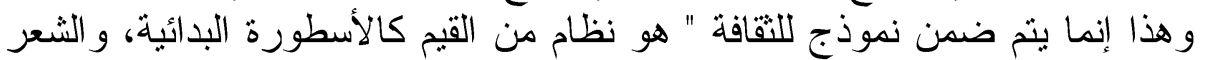

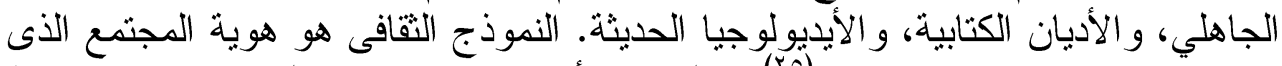

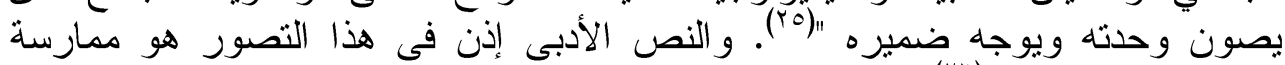

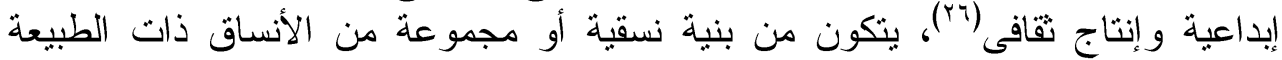

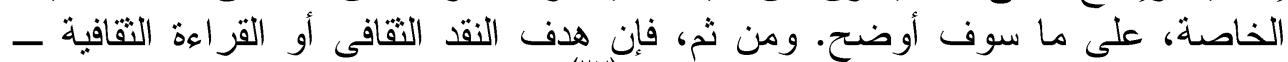

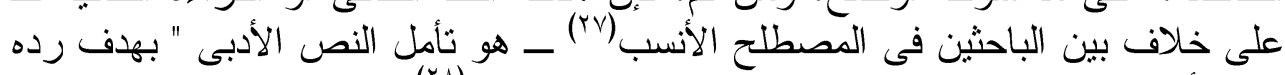

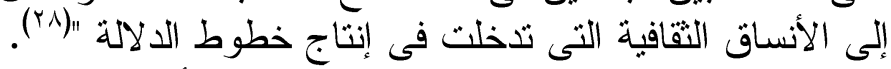

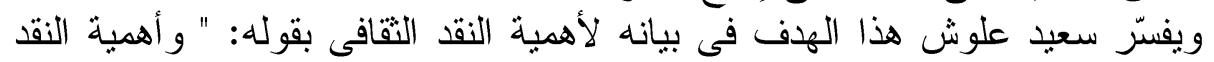

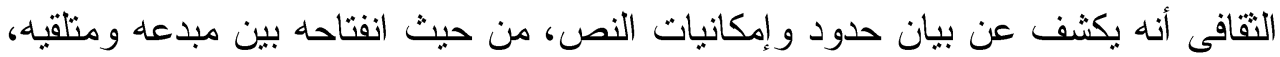

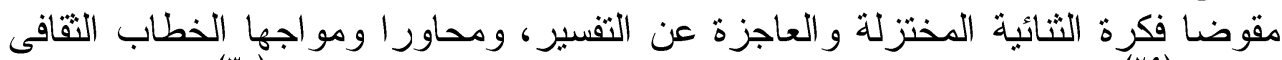

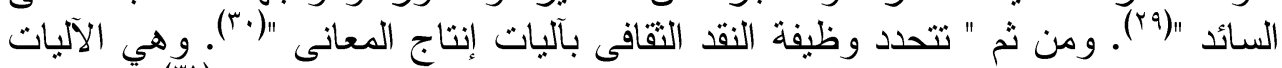

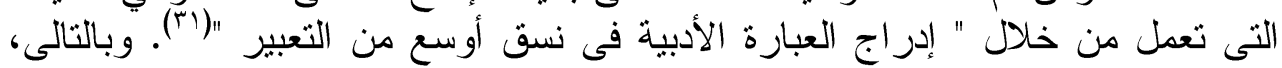

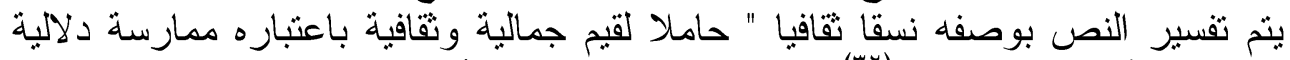

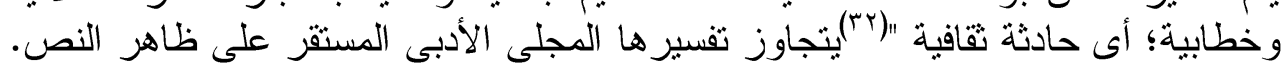

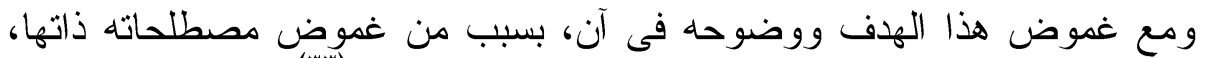

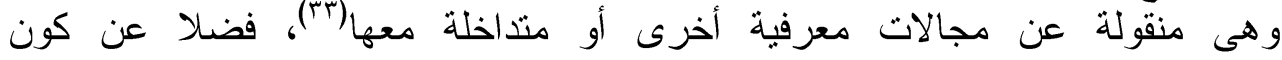

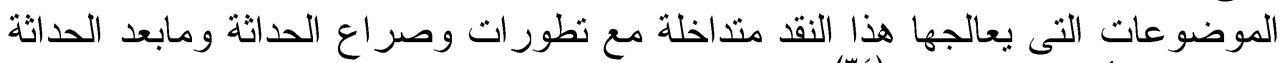

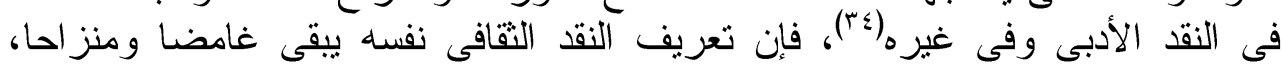

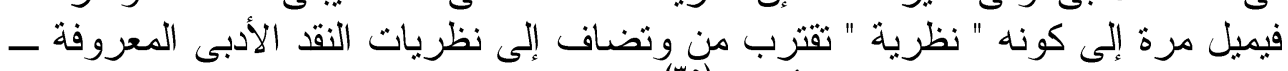

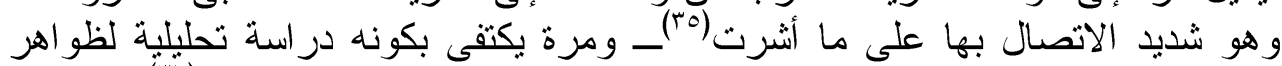

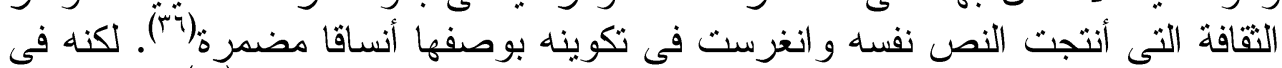

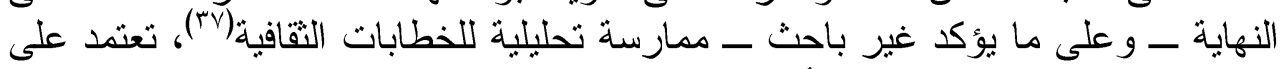

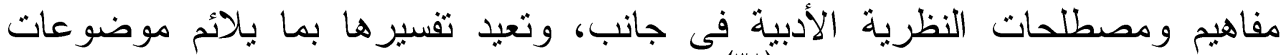

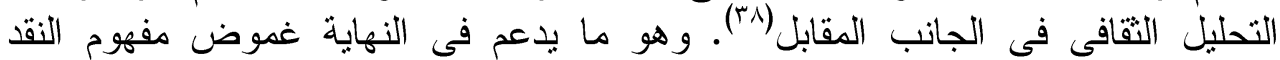

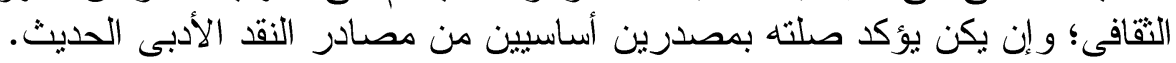

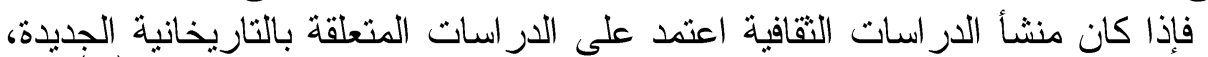

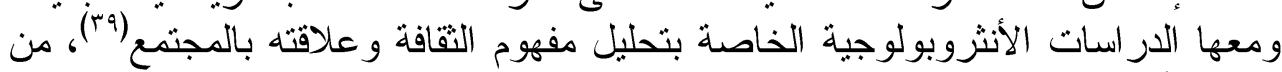

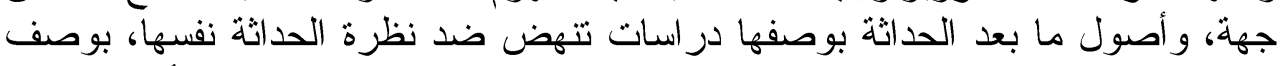

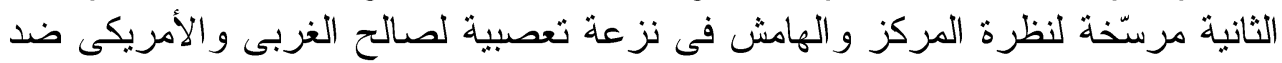




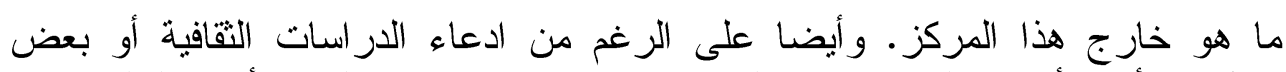

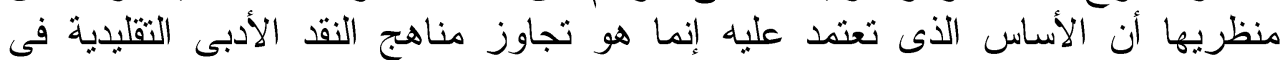

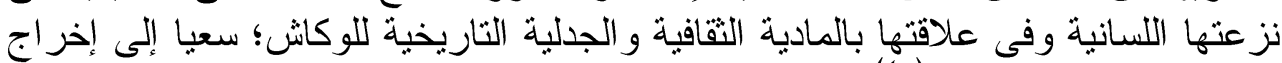

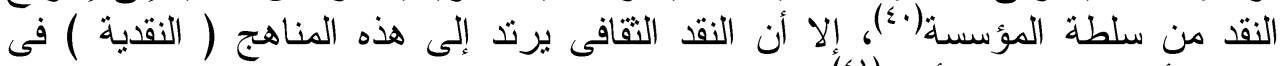

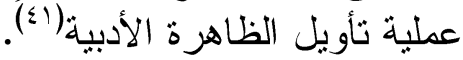

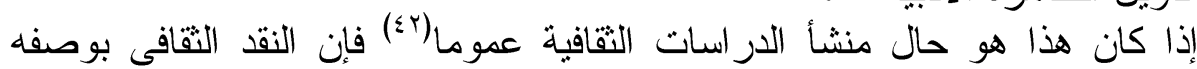

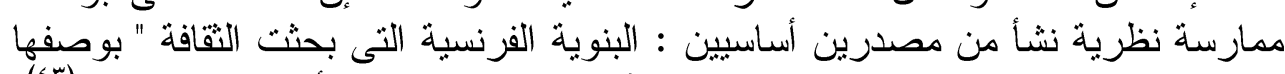

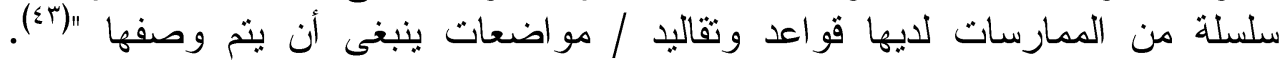

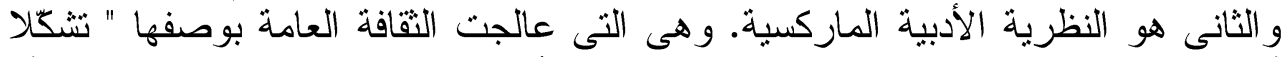

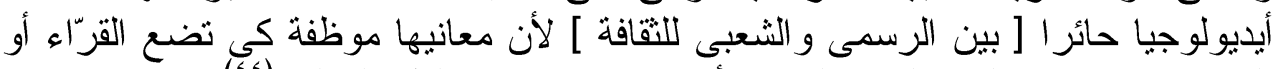

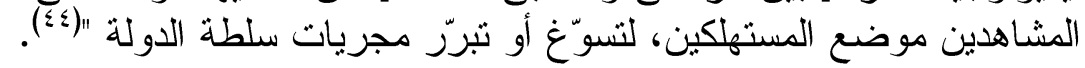

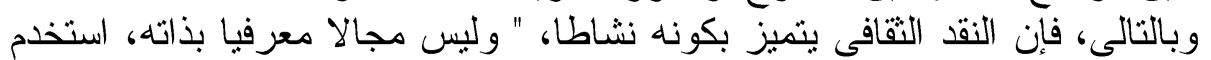

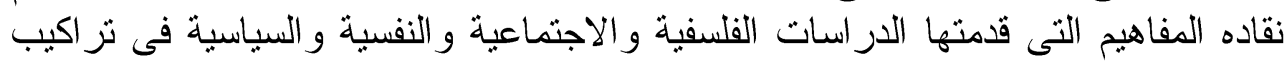

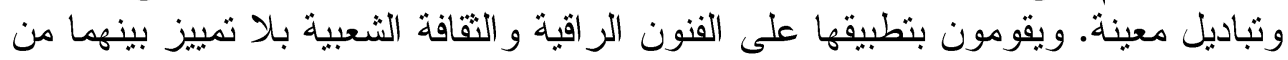

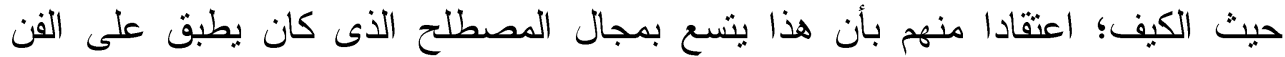

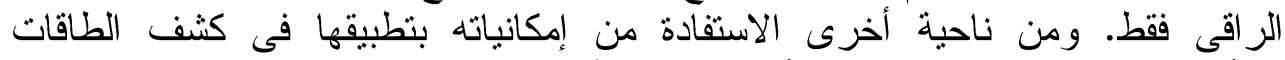

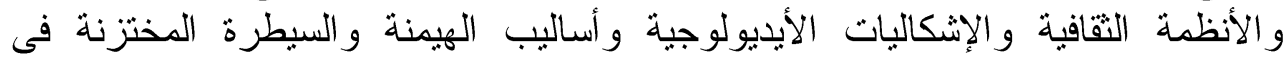

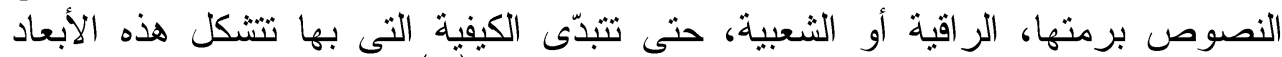

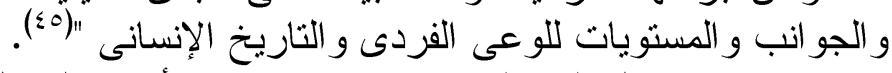

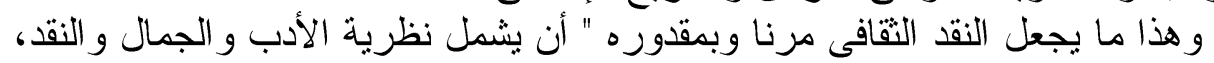

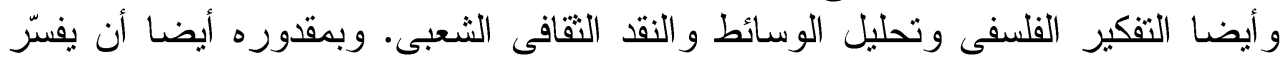

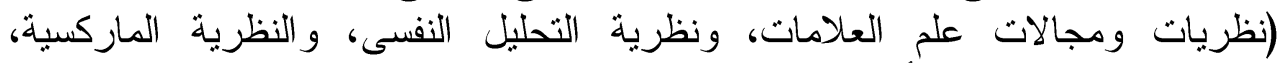

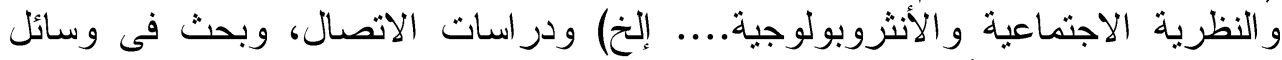

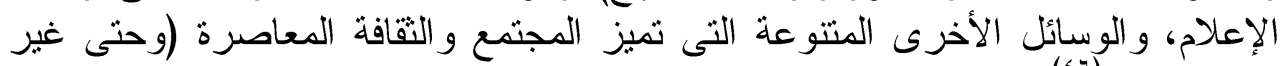

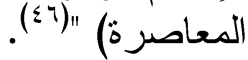

ومن هنا يمكن للباحث أن بلحظ أن النقد الثقافى من حيث طبيعته وممارساته، إنما

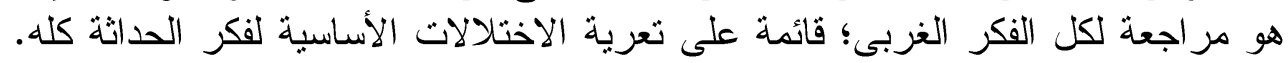

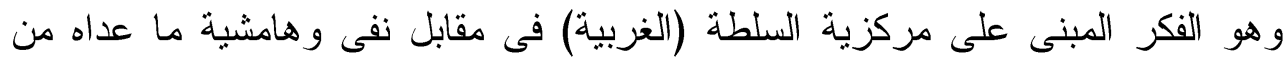

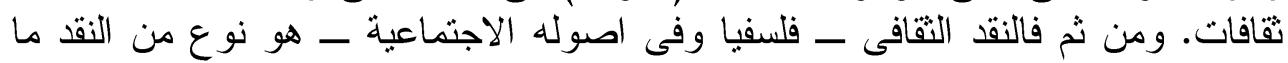

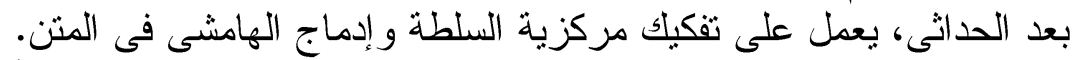

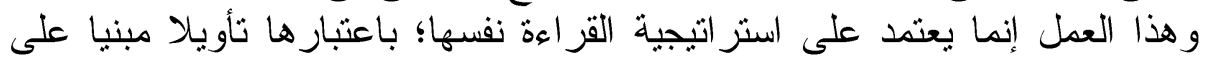

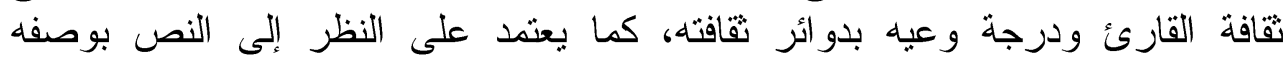

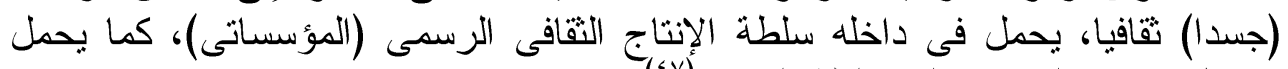

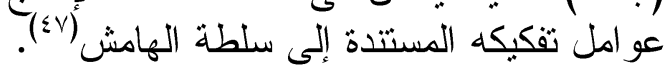

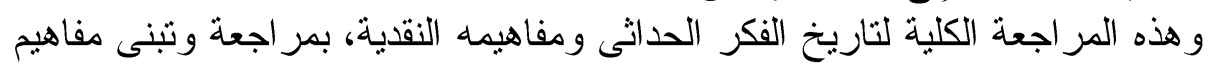

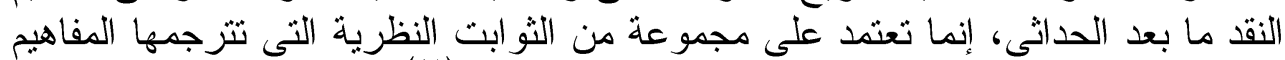

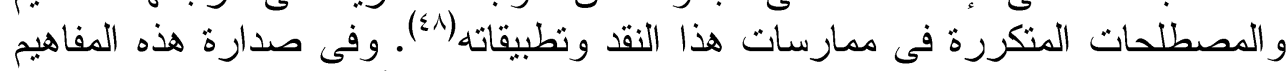

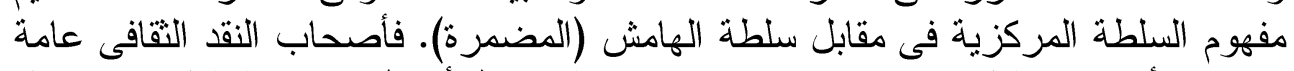

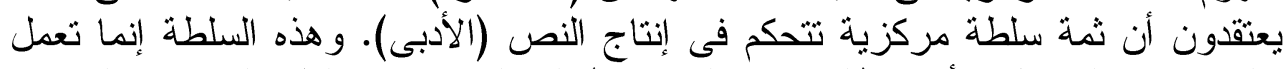

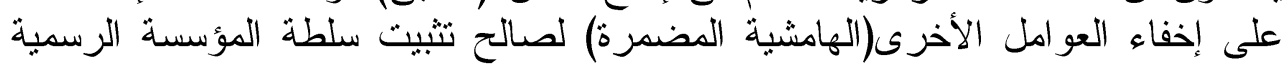




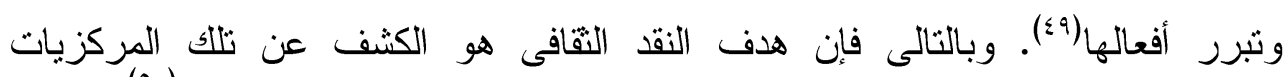

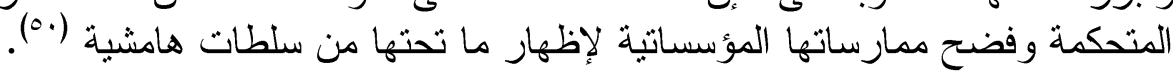

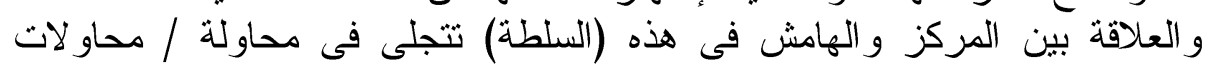

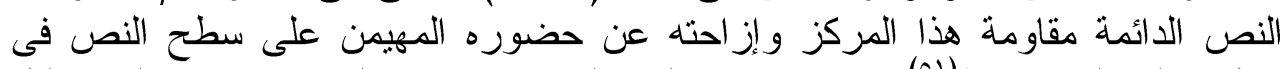

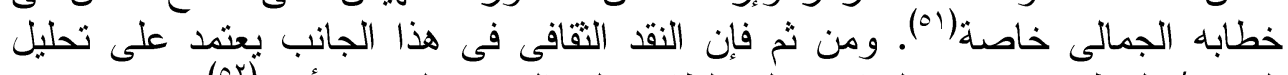

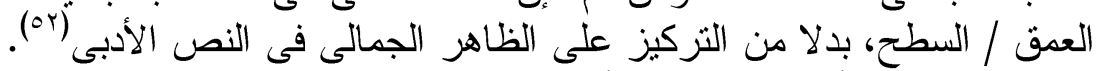

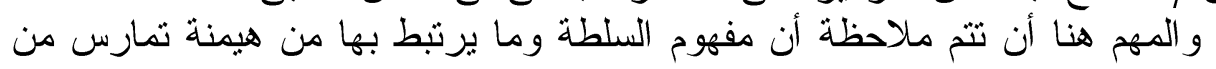

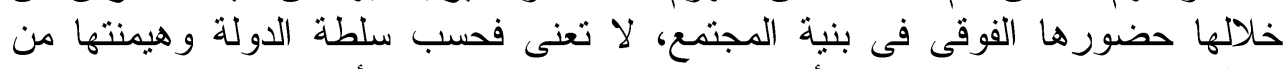

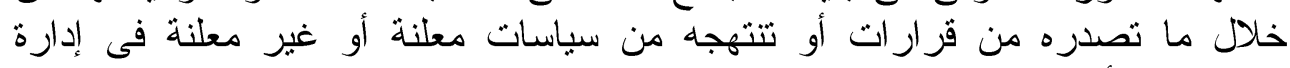

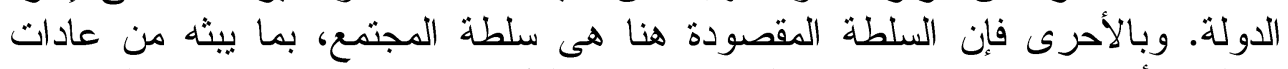

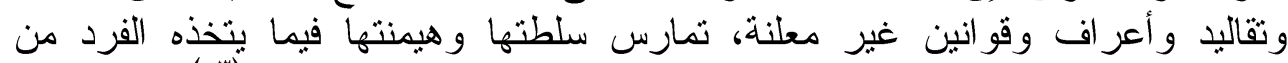

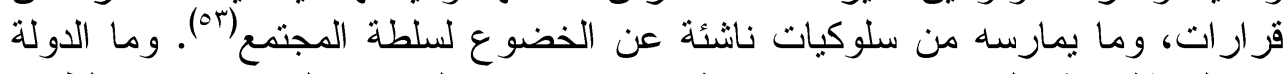

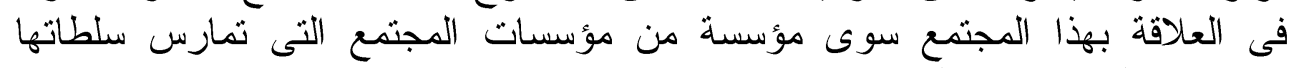

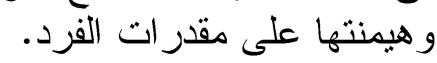

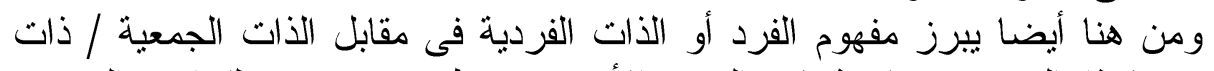

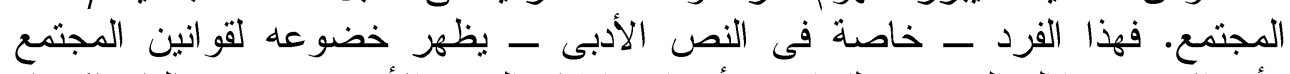

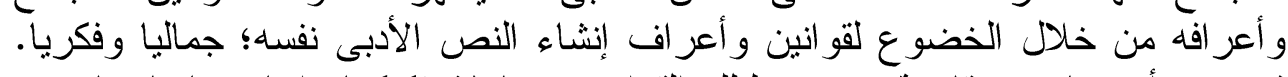

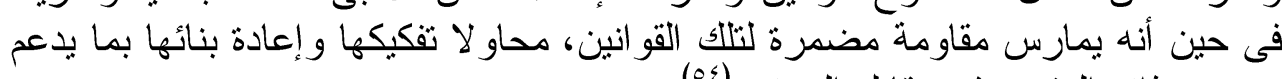

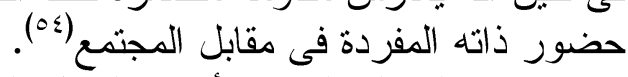

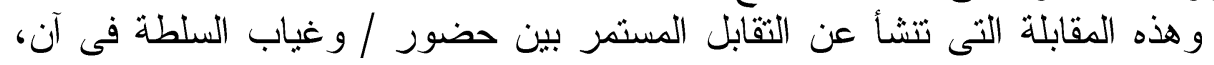

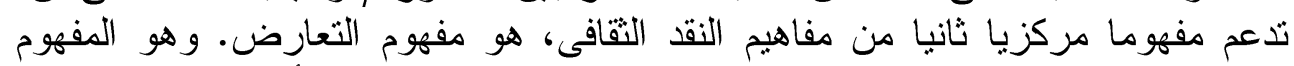

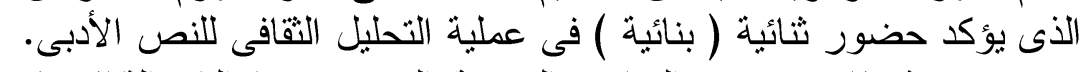

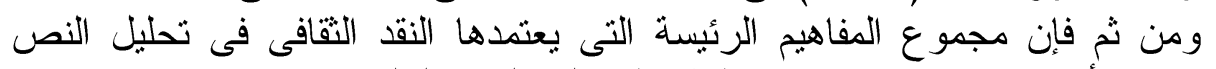

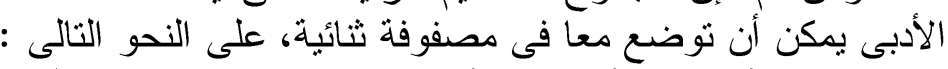

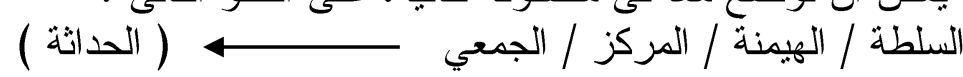

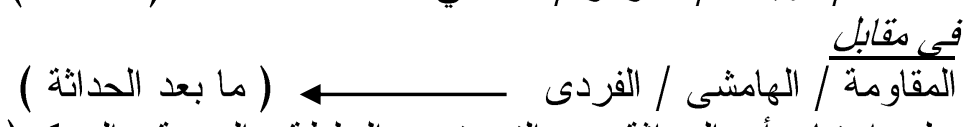

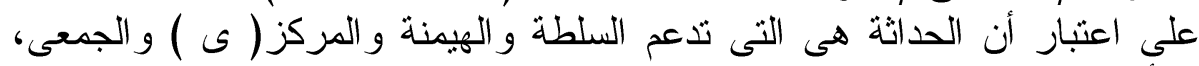

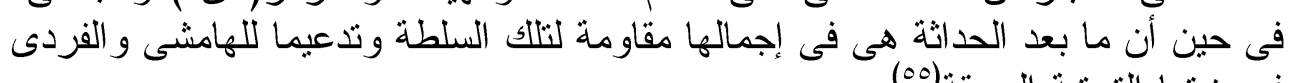

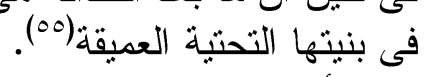
أما المفهوم الرئيسى الأخير الذى بكمل هذه الأهية المنظومة المفاهيمية الخاصة بالنقد

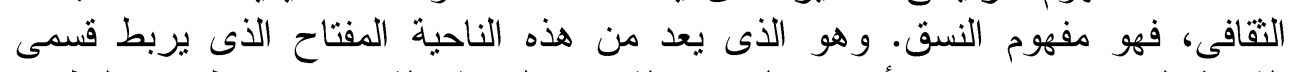

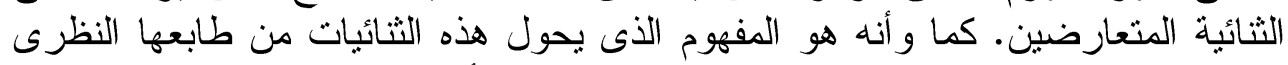

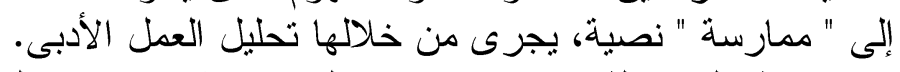

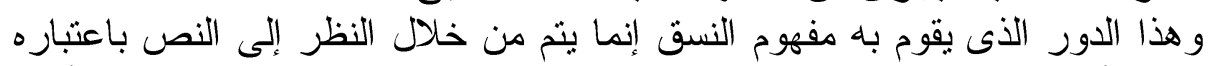

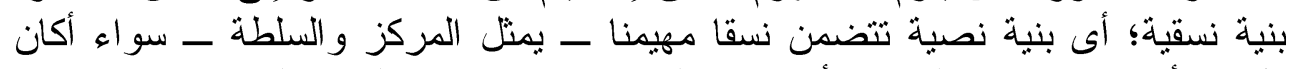

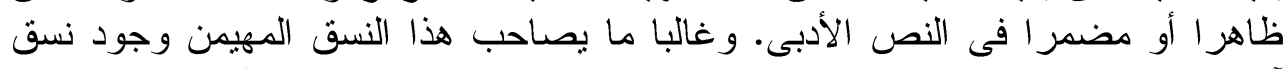

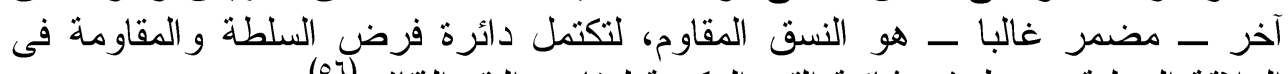
العلاقة الجدلية بين طرفى ثنائية القبم المكونة لمفاهيم النقد الثقافى (باتئ. 


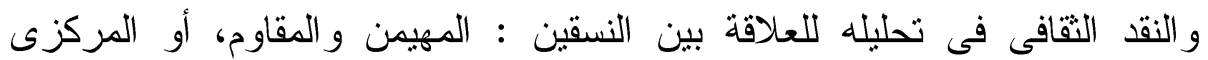

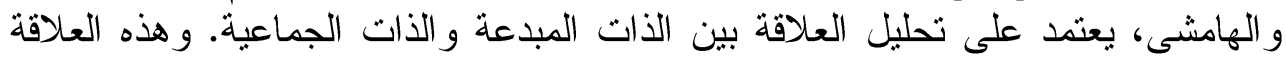

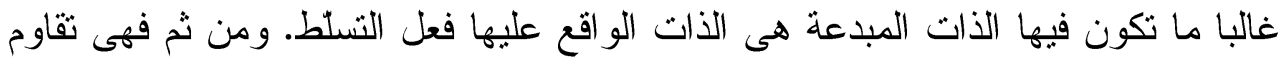

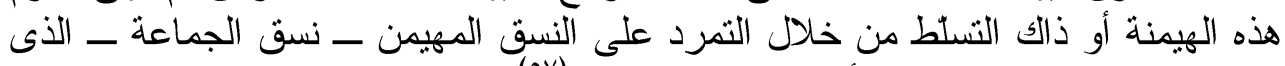

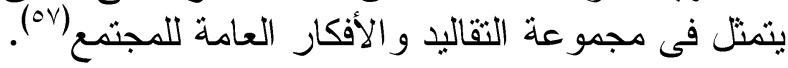

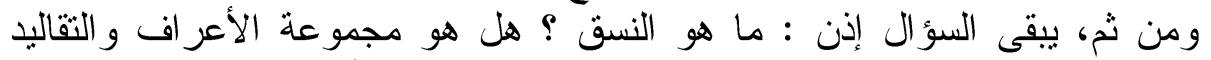

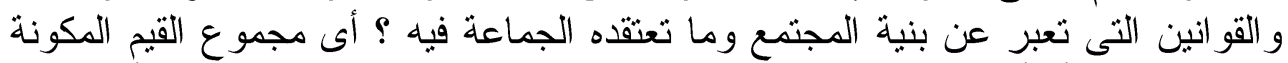

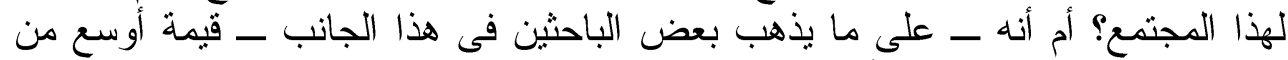

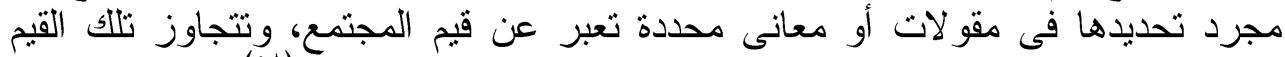

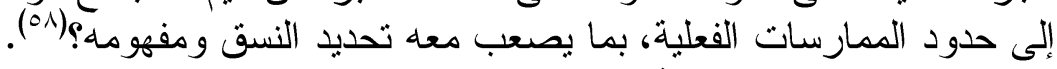

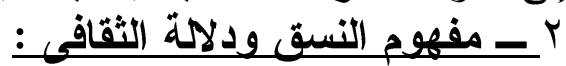

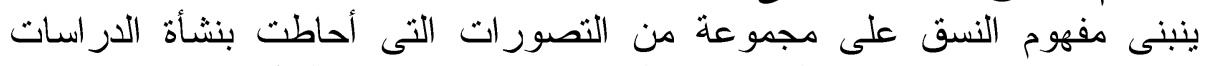

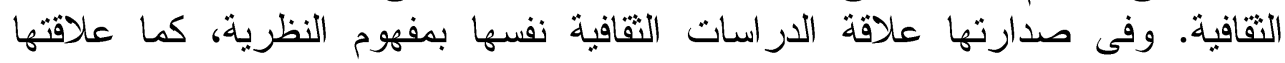
بالنقيضين: المركز والهامش، فى ظل الإنهة الاهتمام بدراسة الثقافة الثعبية وممارساتها

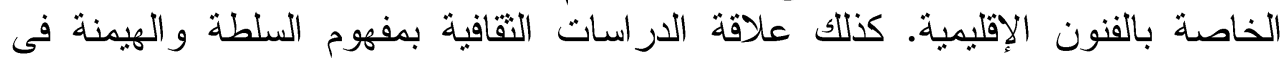

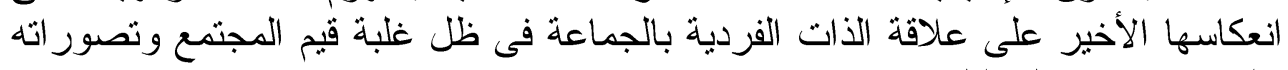
على ما ذكرت قبل قليل.

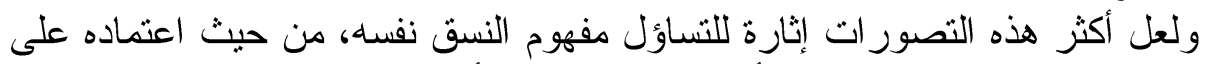

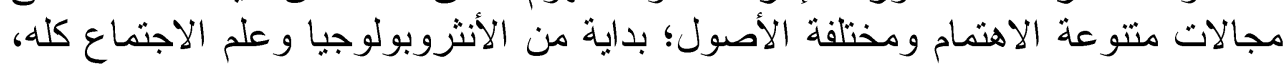

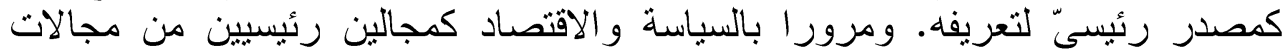

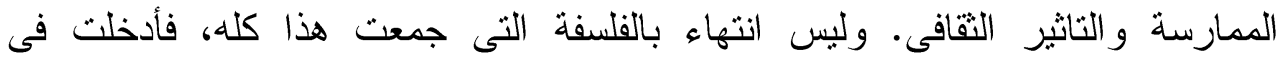

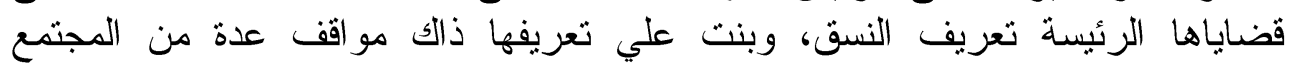
وبلغة ثانية، تعد الثقافة كمفهوم فى هذا المجال، مصدر الئيسيا من مصادر تحديد و الكون.

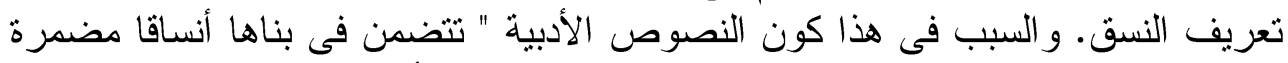

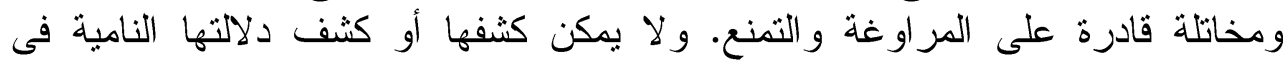
المنجز الأدبى إلا بإنجاز تصوّر كلى حولى حول طبيعة البنى الثقافية للمجتمع، و إدر الك حقيقة

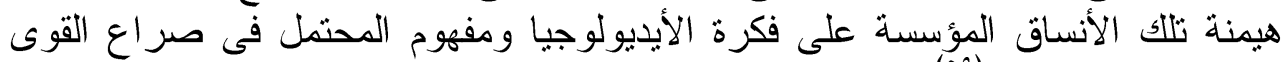

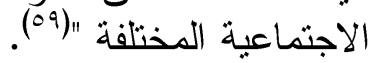

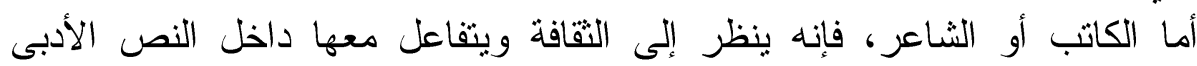

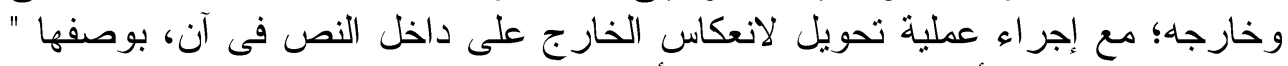

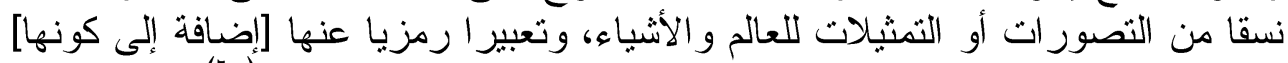

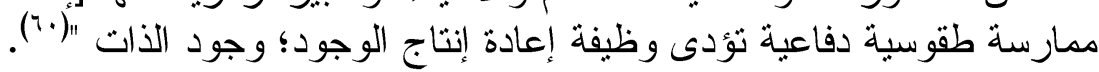

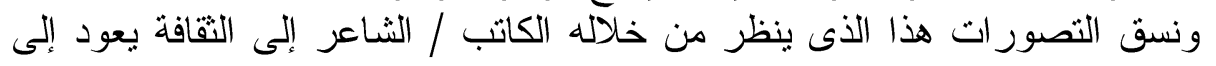

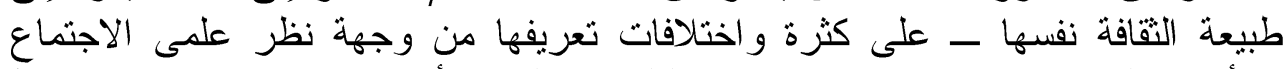

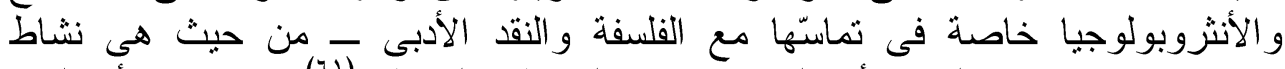

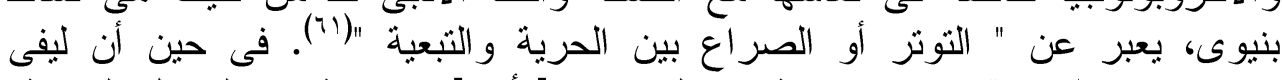

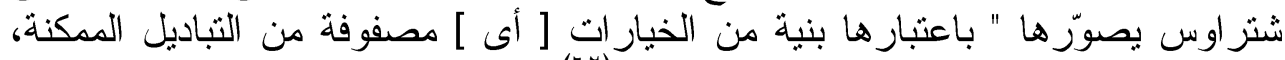

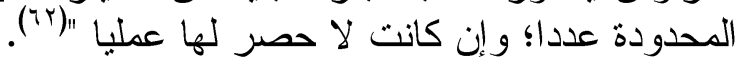




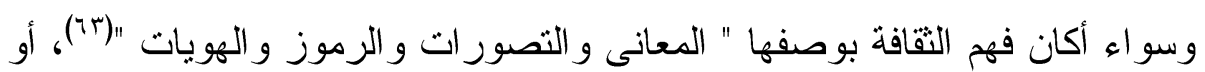

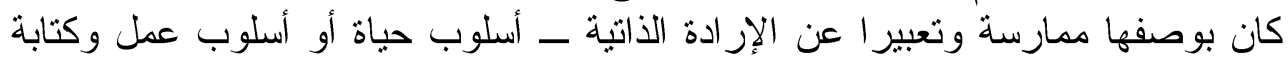

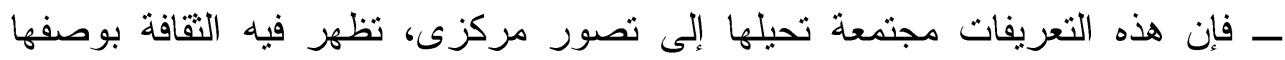

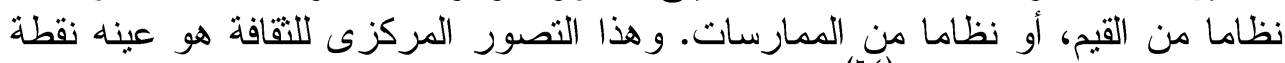

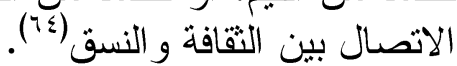

و إن تكن الثقافة من وجهة نظر بعض الدراسات الثقافية تتجاوز فكرة النظام بمعناها

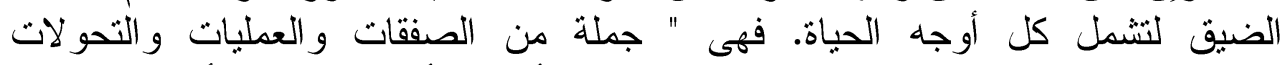
و الممارسات و التكنولوجيات و المؤسسات التى تتتج أشياء و أحداثا ( مثل الأفلام و القصائد

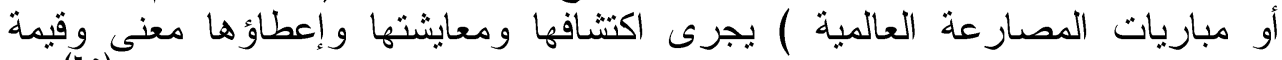

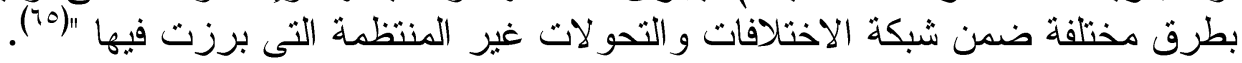

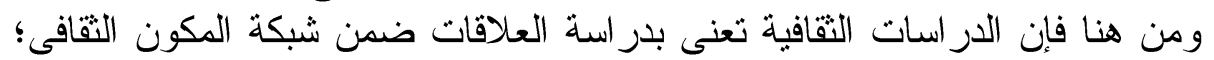

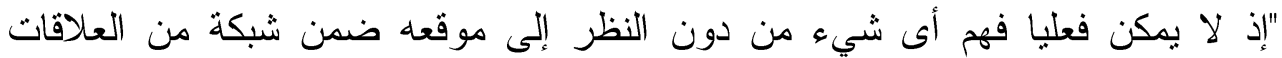

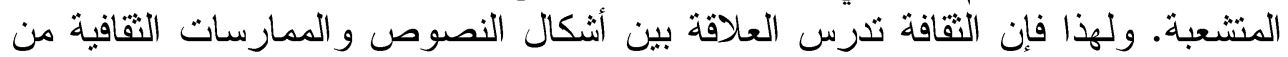

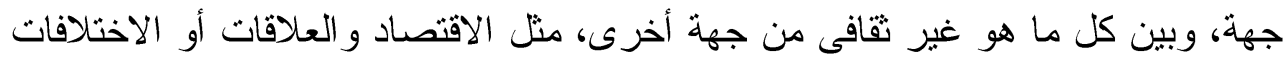

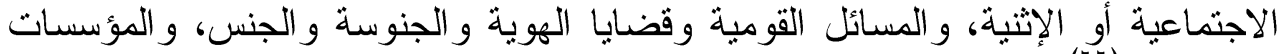
الاجتماعية" (74).

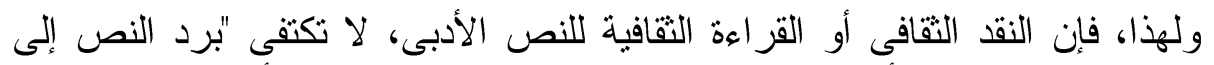

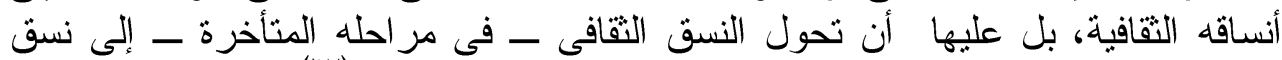

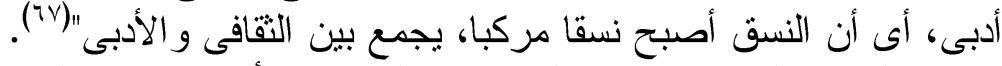

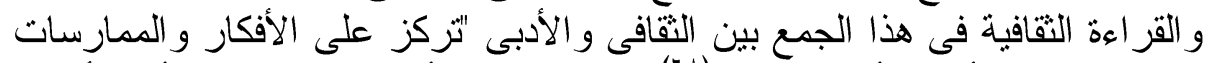

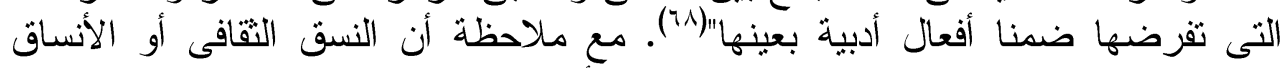

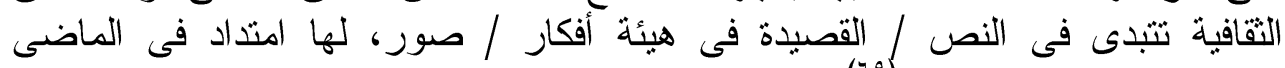

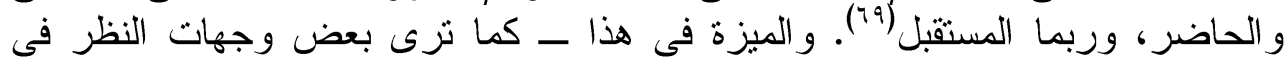

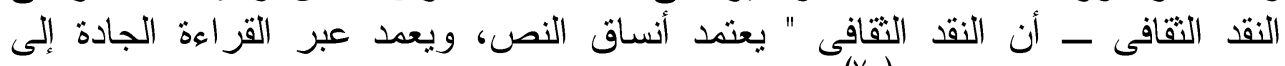

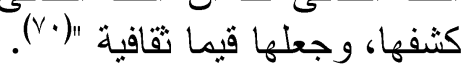

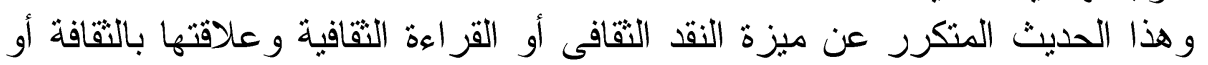

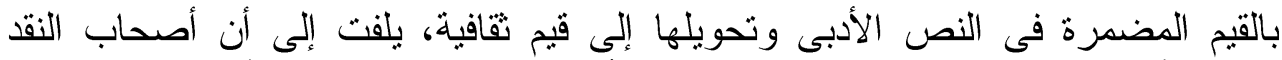

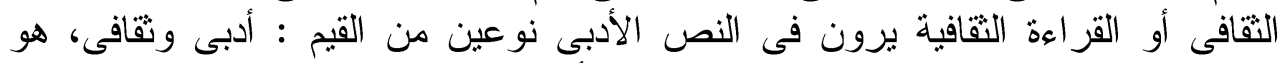

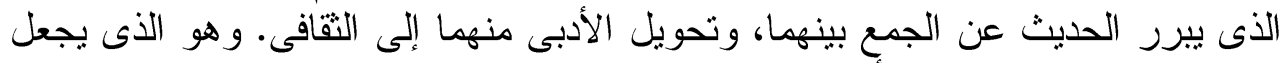

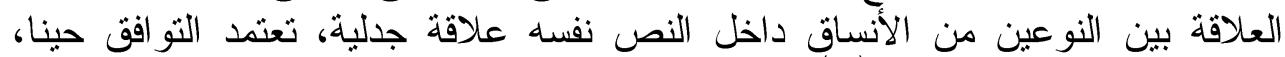

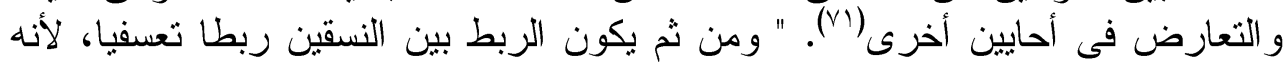

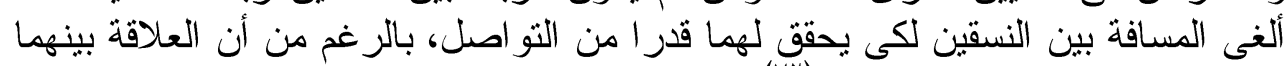

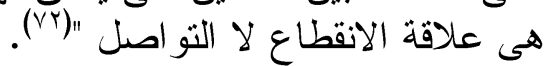
وسبب هذا الانقطاع أو الجدل في عملية القراعة الثقافية بين الثقافى و الادبى أن "

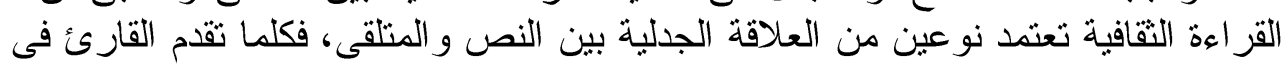

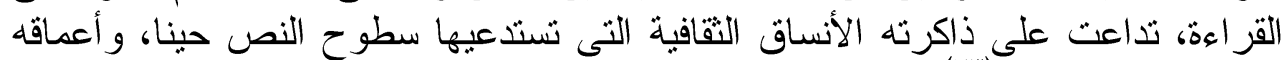

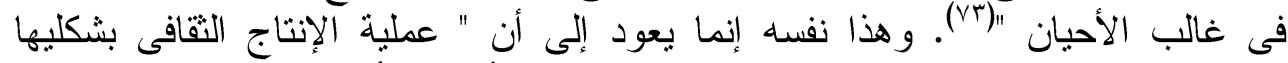

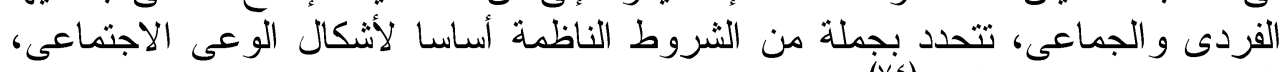




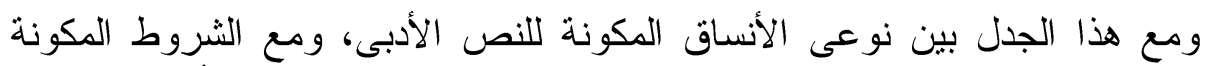

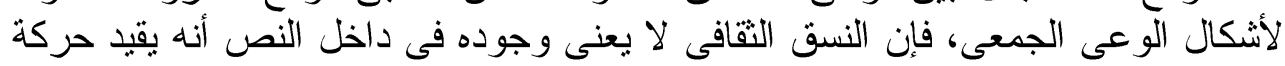

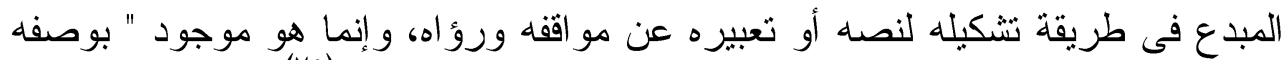

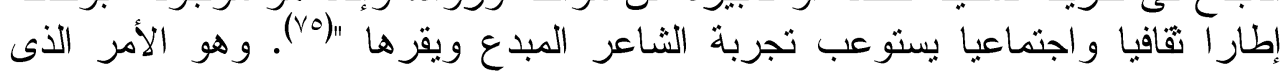

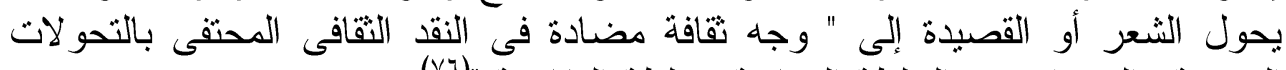

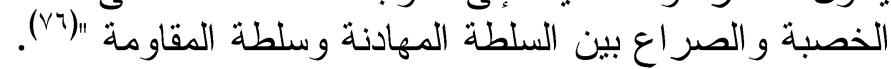

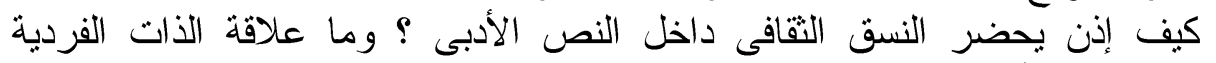

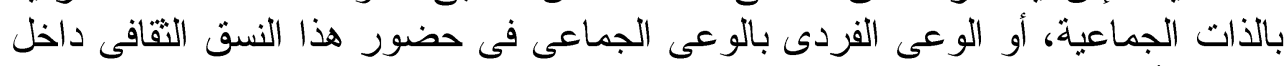

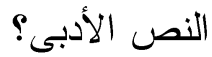
إذا كانت القراعة الثقافية " تسعى إلى رصد التى التقاعل بين مرجعية النص الثقافية

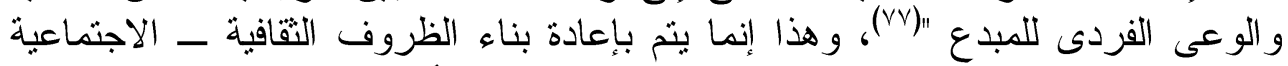

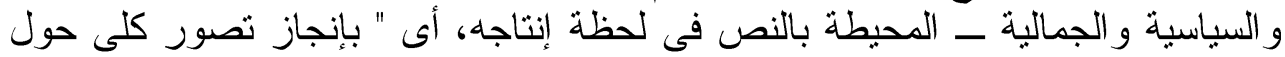

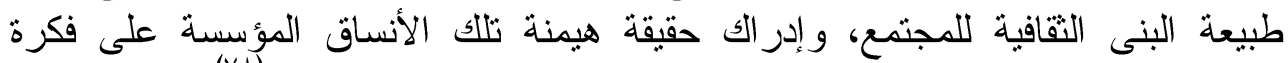

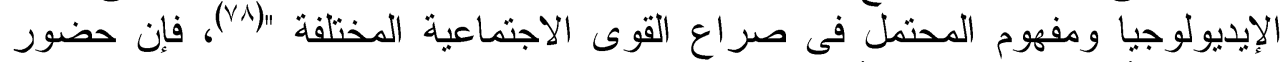

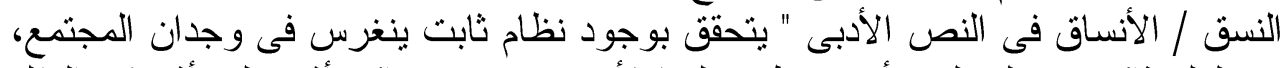

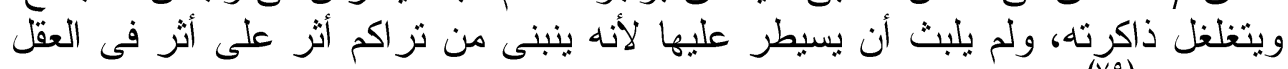

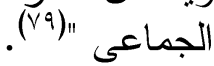
ويفسّر الغدّامى هذا الحضور فى حديثه عن النسق بوصفه بنية مضمرة، "يتحدد الونى

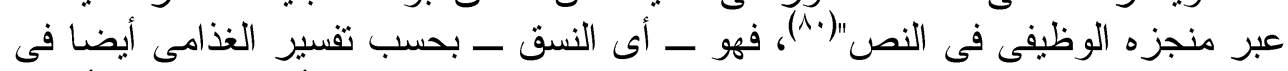

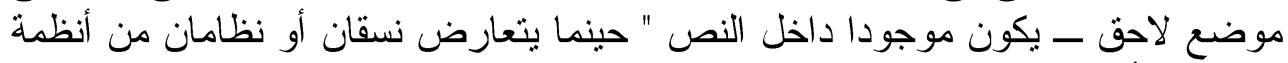

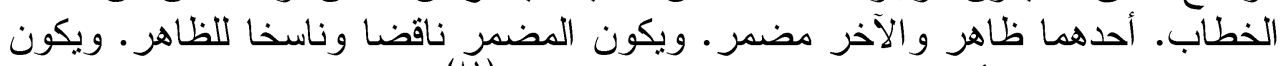

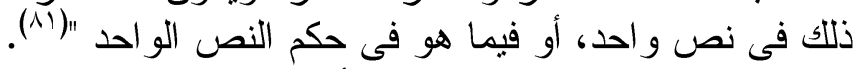

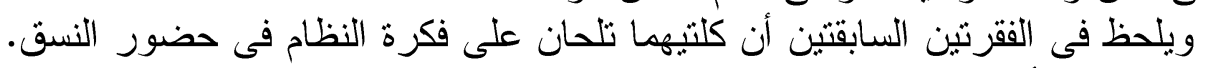

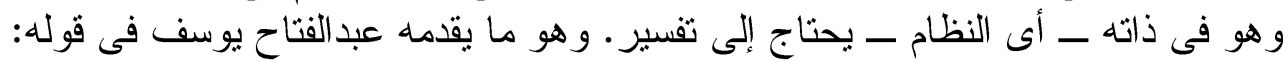

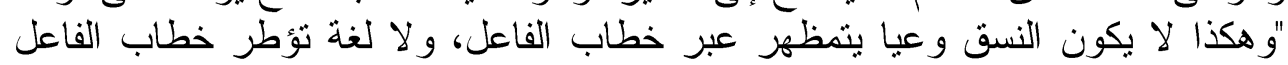

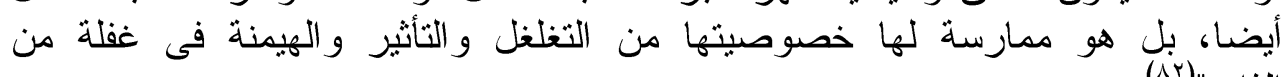
الأذات"(ir).

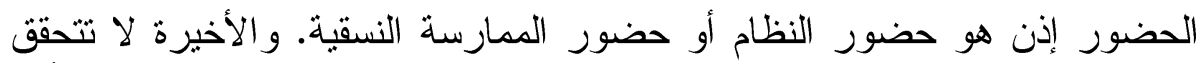

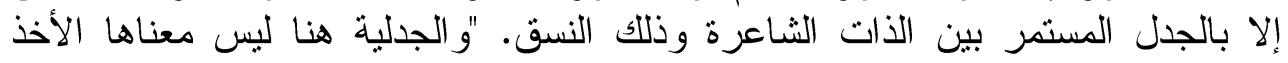

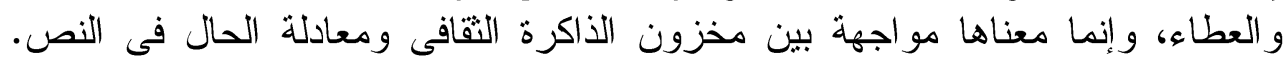

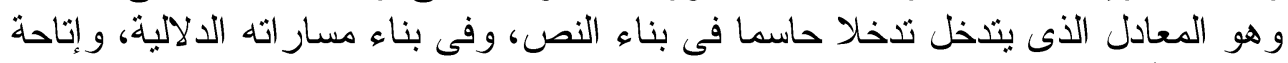

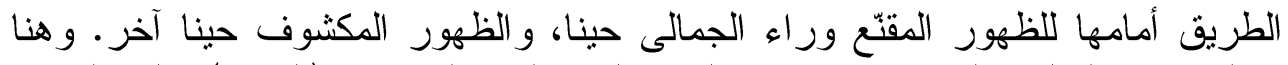

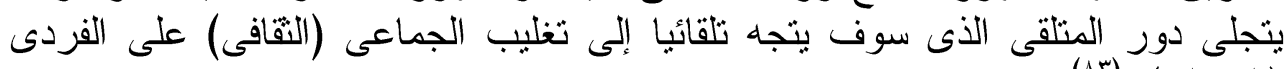

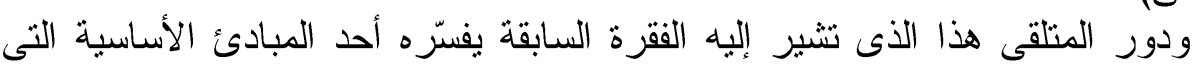

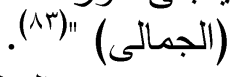

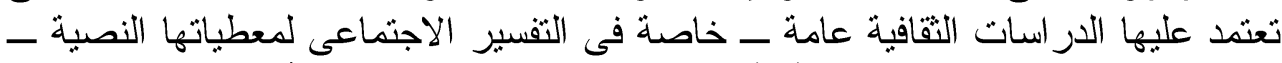

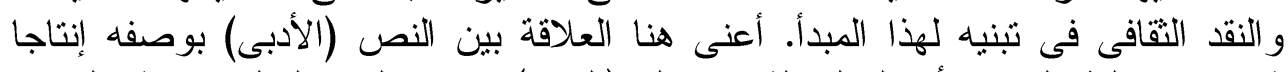

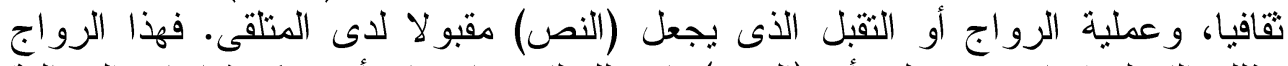

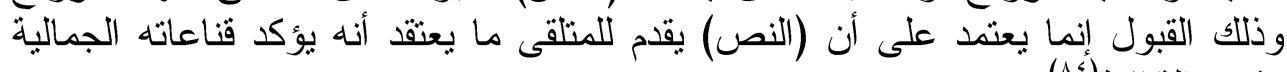




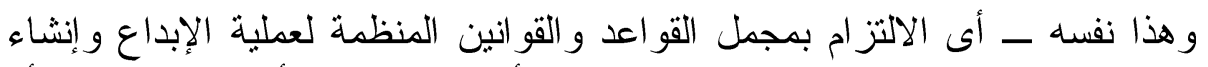

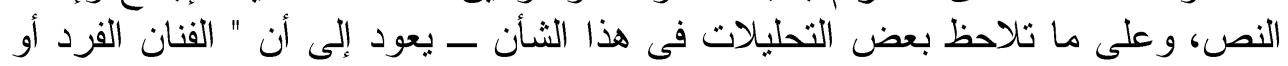

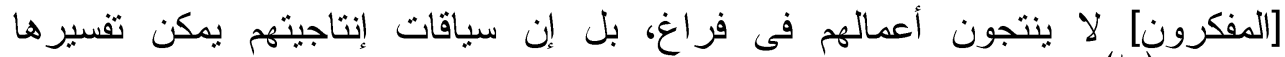

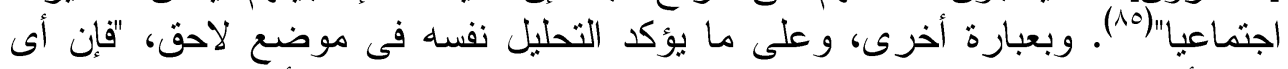

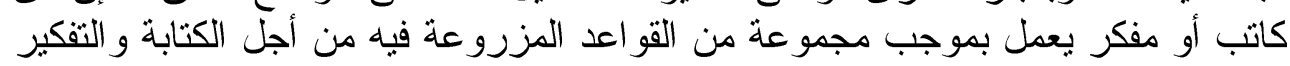

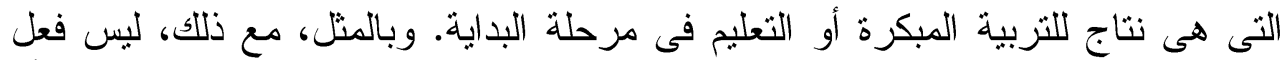

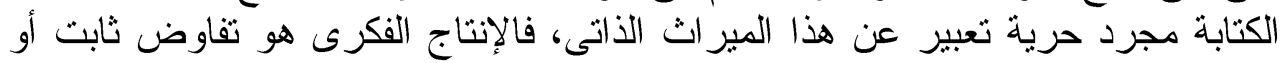

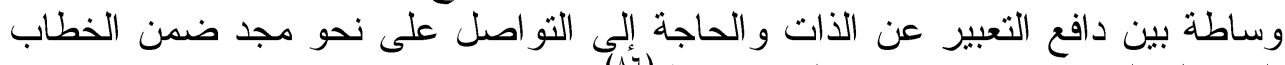

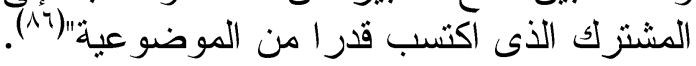

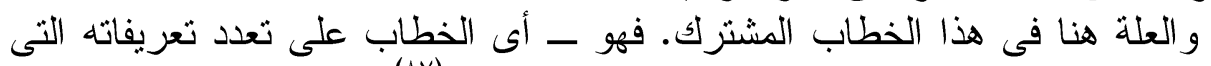

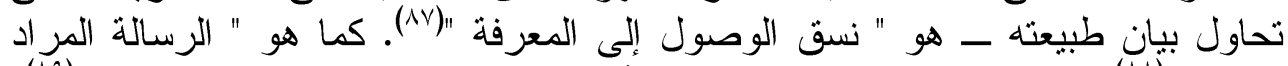

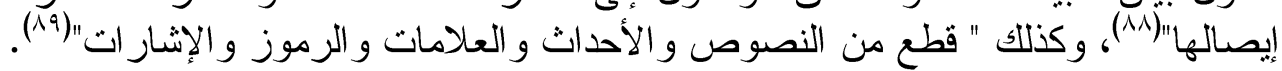

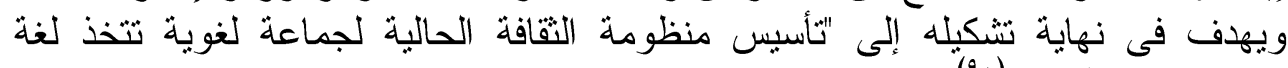

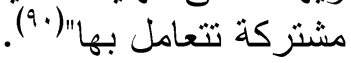

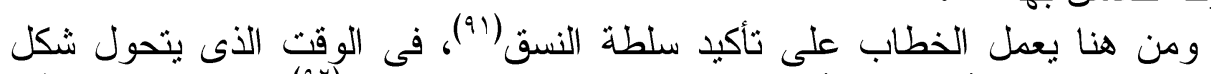

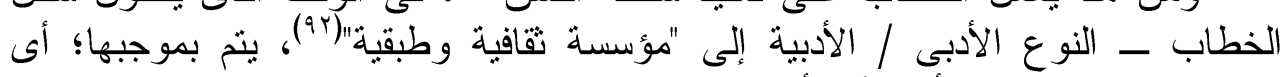

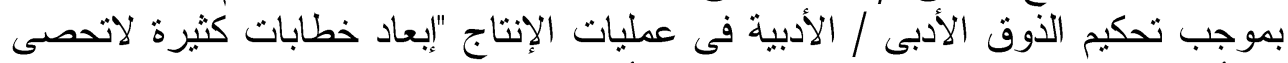

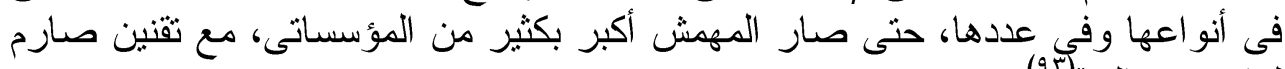

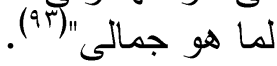

وفى ضوء هذه هذه العلاقة المركبة بين الثقافة / النسق / الخطاب فإن المبدع حين

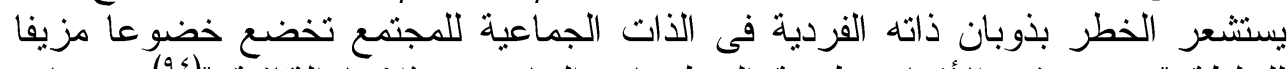

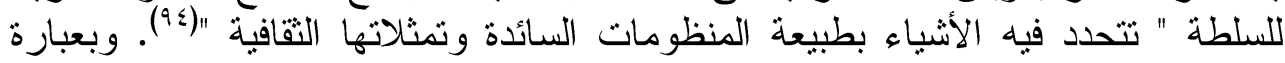

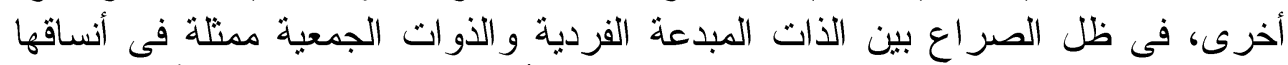

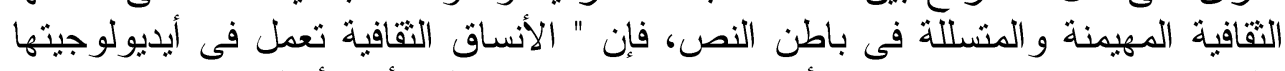

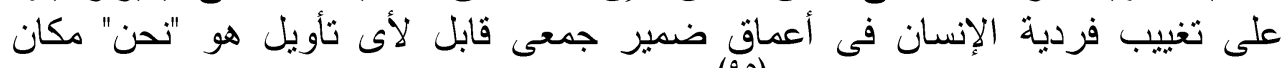

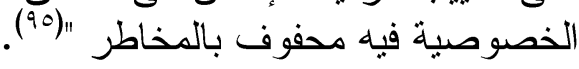

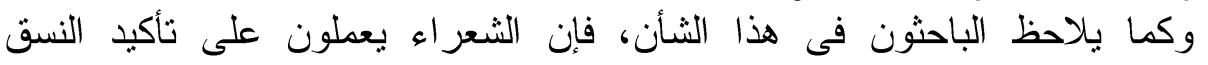

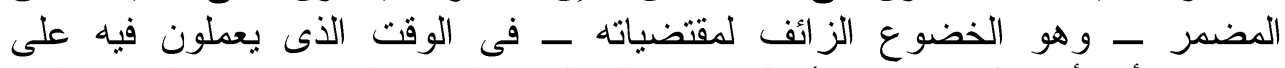

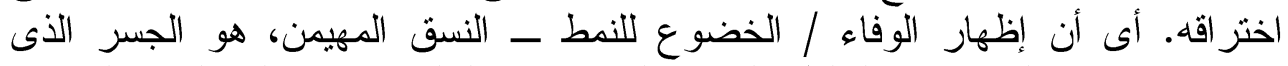

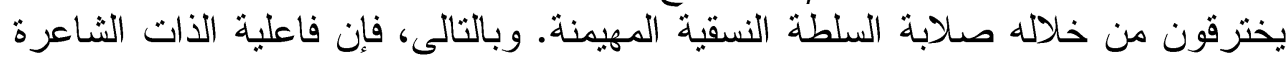

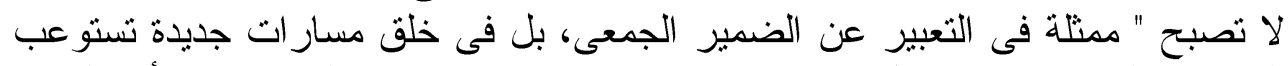

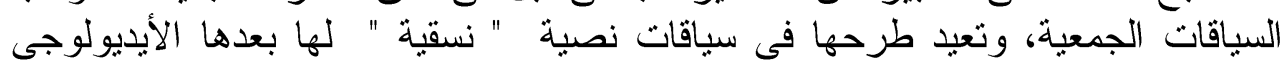

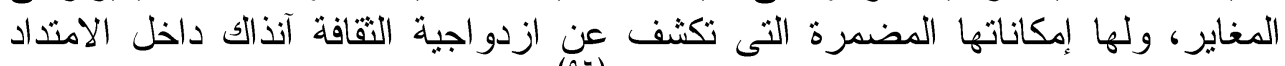

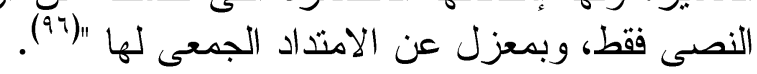

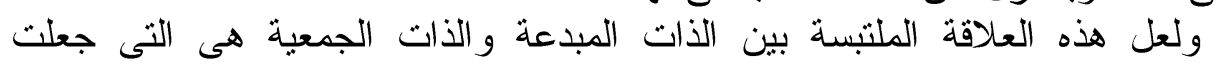

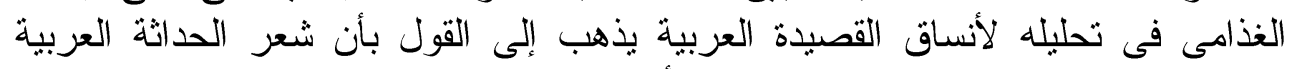

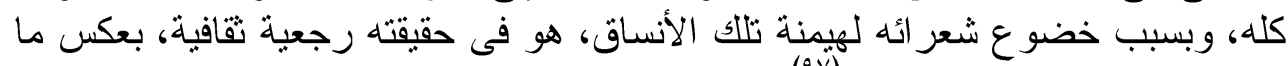

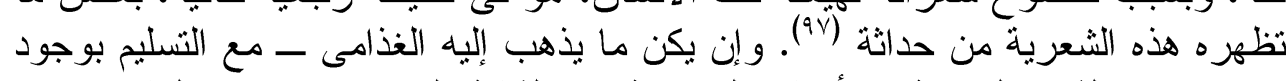

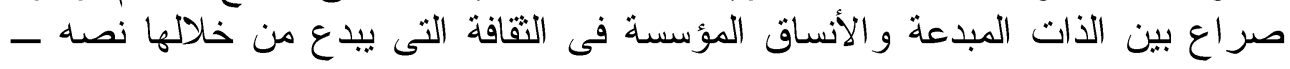


يو هم أن هدف النقد الثقافى هو إثبات رجعية الثقافة المعاصرة، لا حداثتها وجدتها. بينما

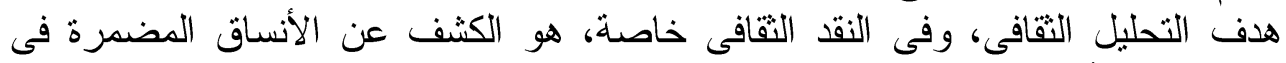

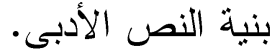
و هذا الكشف لا بنتهى بالضرورة إلى إصدار حكم قيمة برجعية النص أو حداثثه،

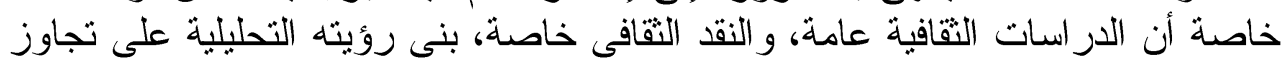

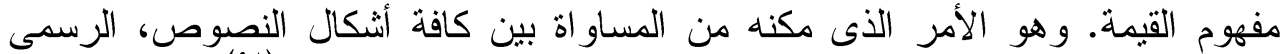

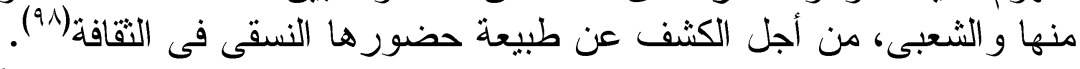

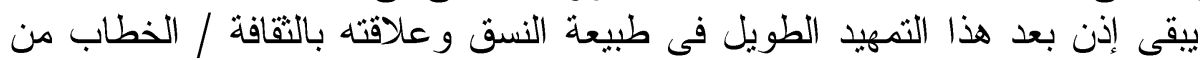

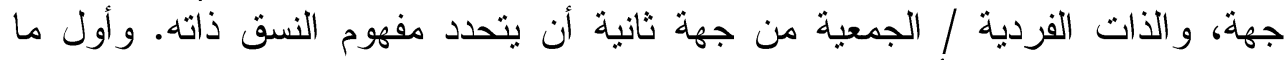

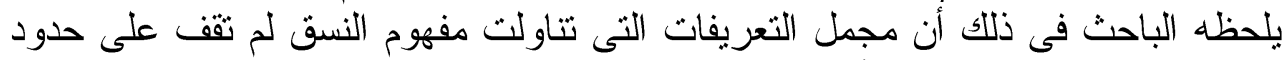

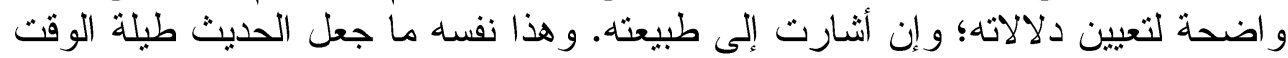

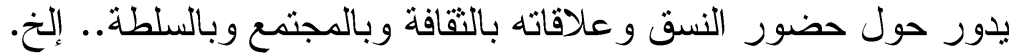

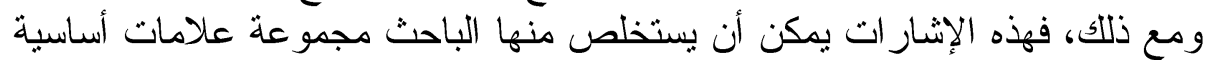

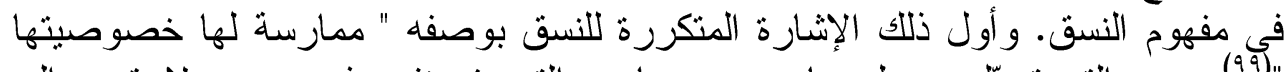

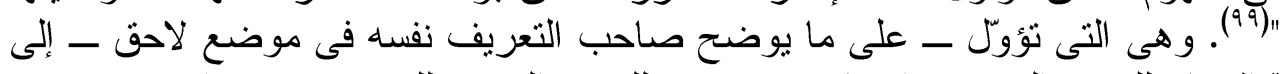

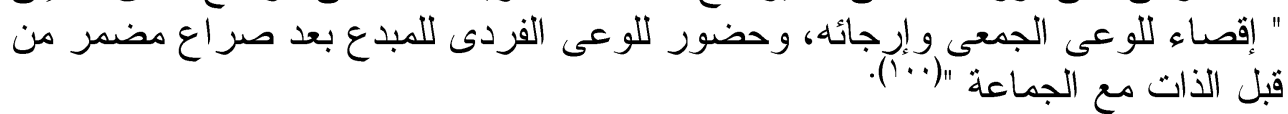
ومعنى ذللك أن الممارسة المقصودة هى إقى إقصاء للوعى الجمعى فى مقابل حضور

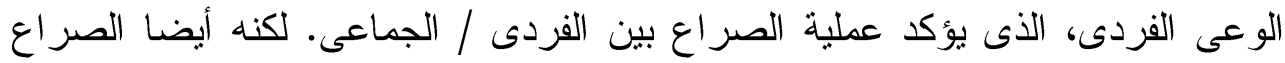

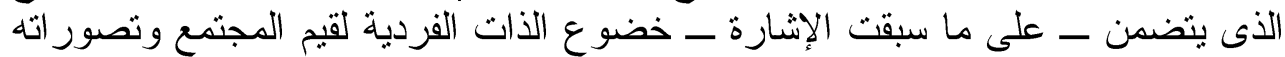

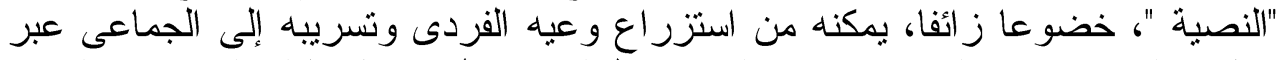

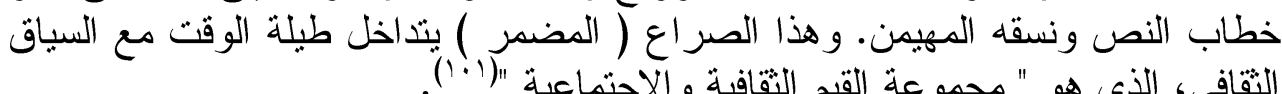

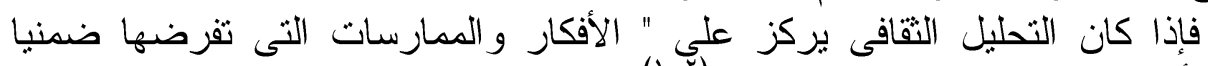

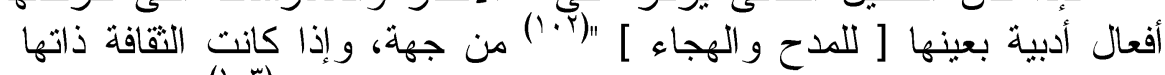

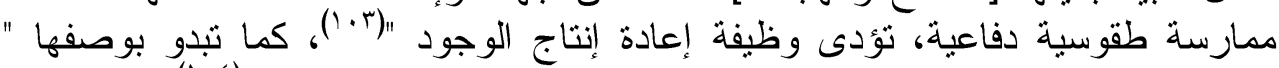

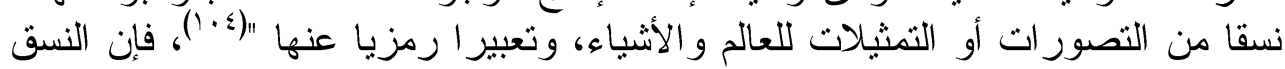

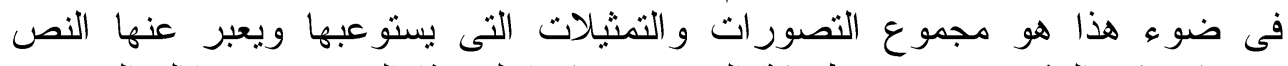

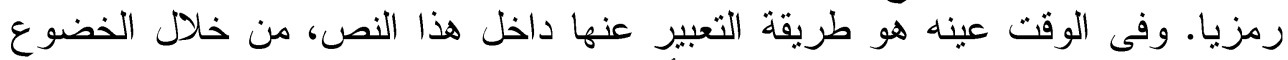

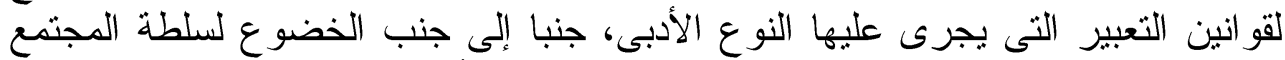

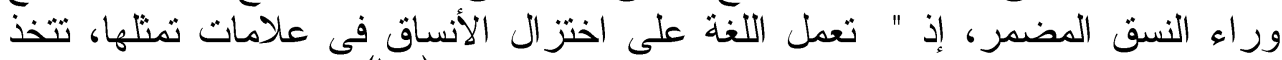

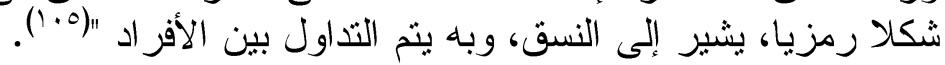

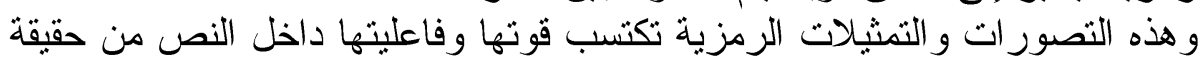

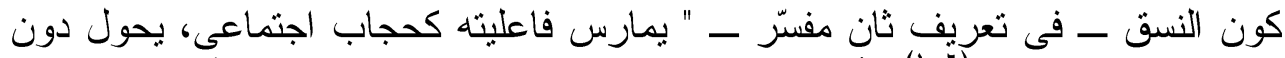

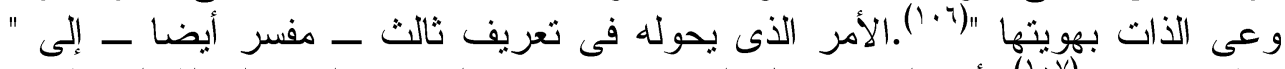

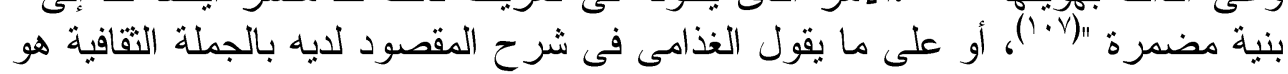

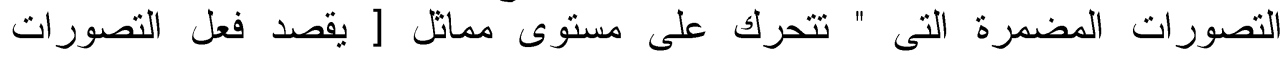

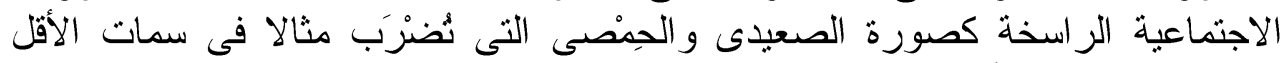

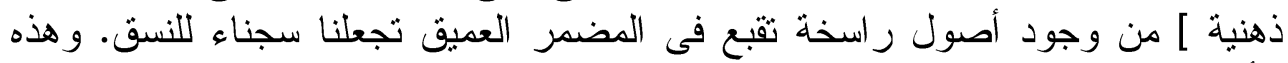
الأصول قديمة قدم اللغة ذاتها، ومنذ كانت اللغة مادة غير قابلة للنفاد، ويقوم استخدامنا 


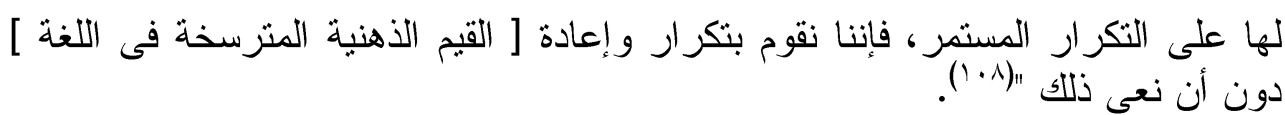

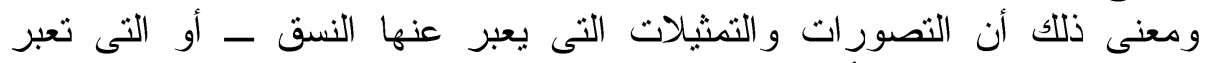

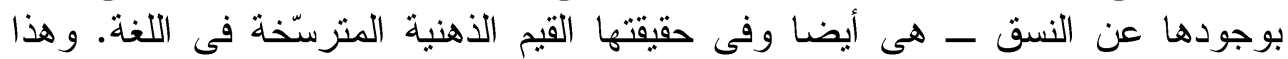

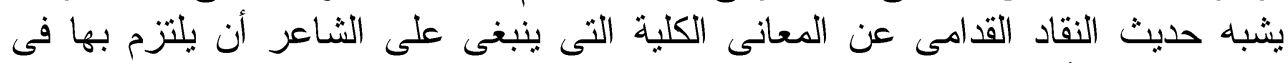

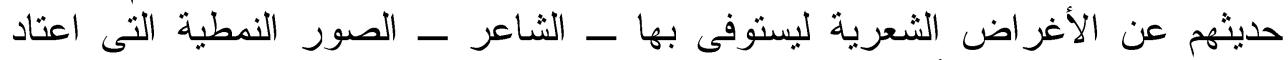

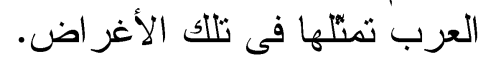

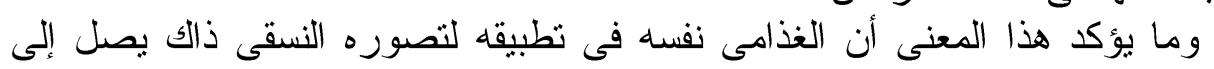

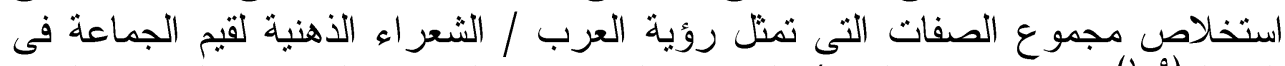

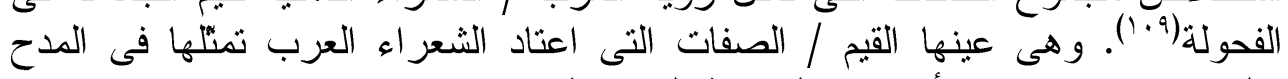

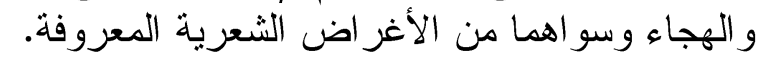

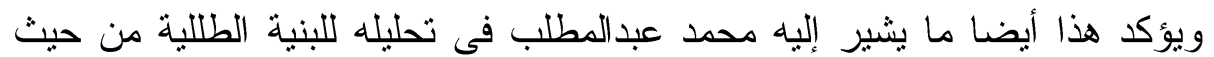

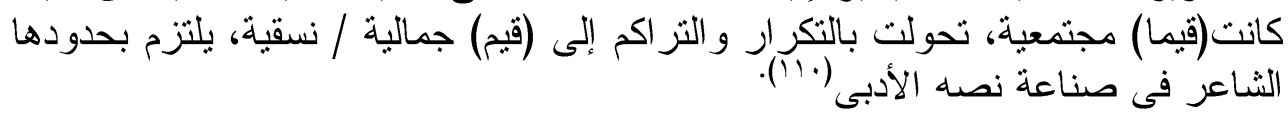
النسق إذن هو بنية مضمرة، تمثل مجموع التصور ات وات والتمثيلات الرمزية للغة،

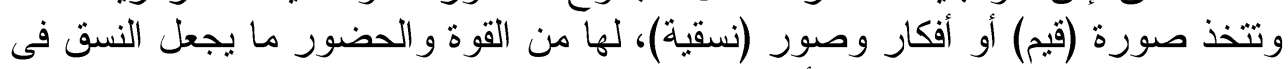

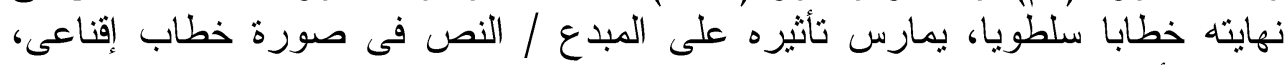

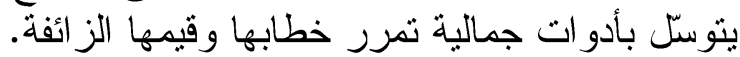

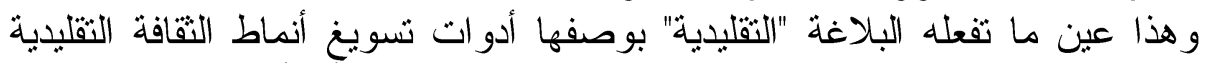

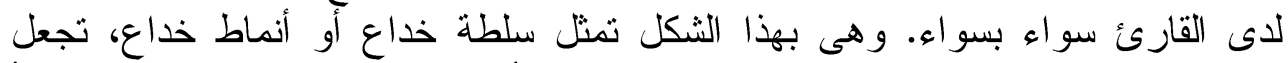

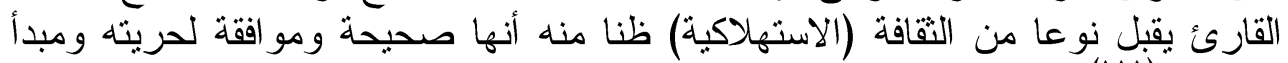

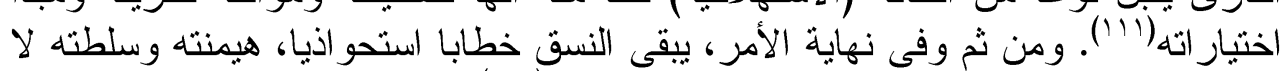

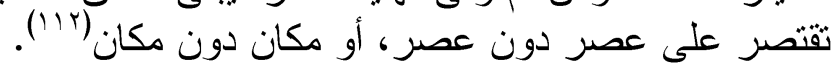

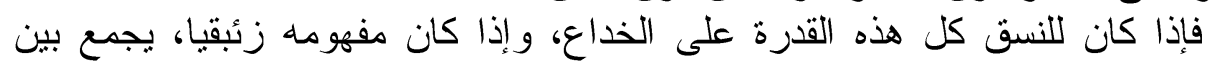

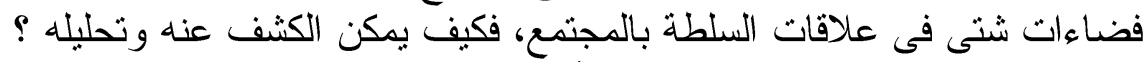

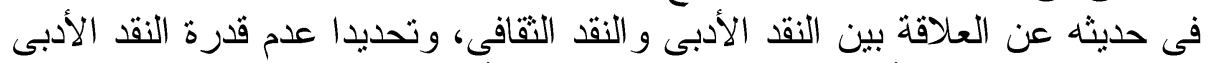

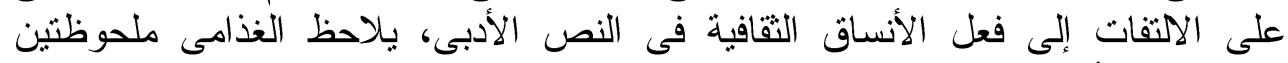

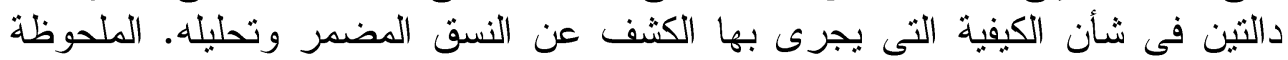
الأولى تتعلق بتحديد المقصود بالنسق المضمر والى الفرق بينه وبين الدلالة (الجمالية)

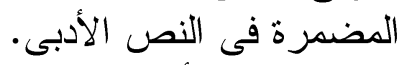

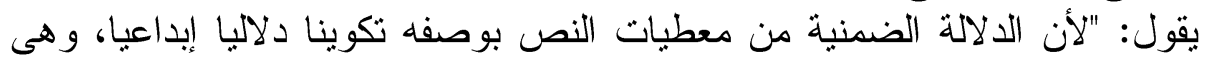

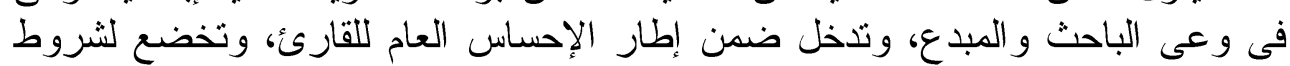

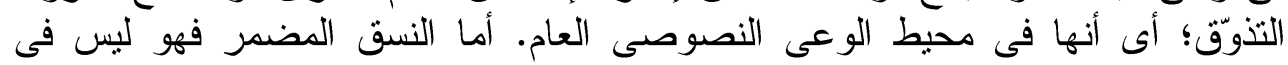

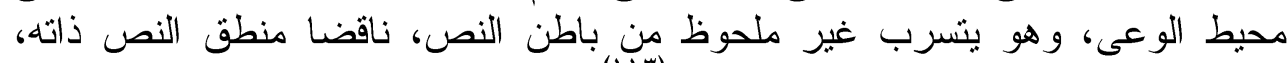

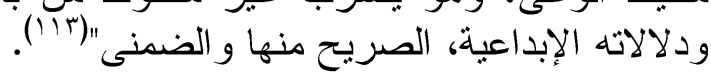

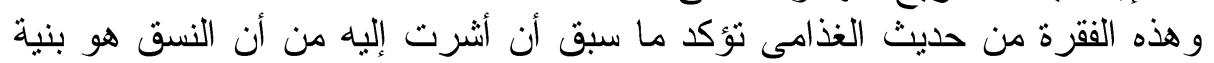

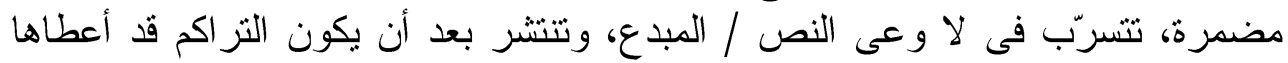

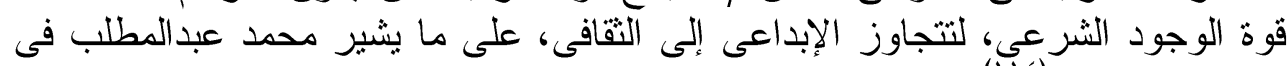

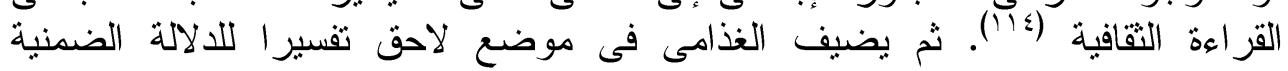


(الجمالية) فى النص، مخصصا الحديث عن الصورة الشعرية: "بمعنى أن الصورة

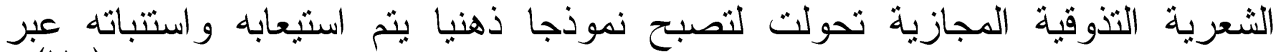

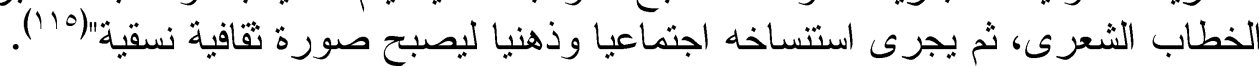

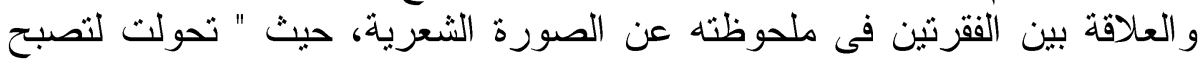
نموذجا ذهنيا يتم استيعابه و استنباته عبر الخطاب الشعرى ". و وهى المعنى عينه الذى يفه أيضا من كلام عبدالمطلب فى حديثه عن النسق من حيث بدايته كتقليد اجنماعى يتحول

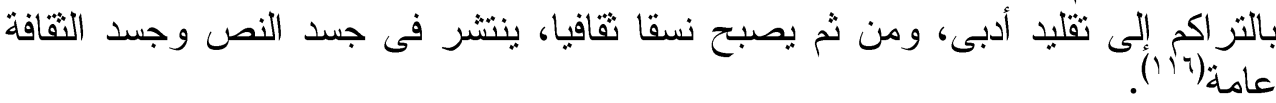

ومعنى ذلك أن الباحث إذ هو بصدد رصد وتحليل النسق فى النص الأدبى يواجه

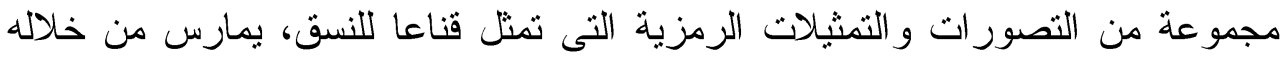

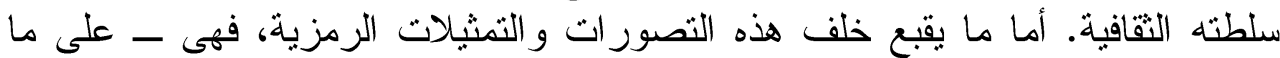

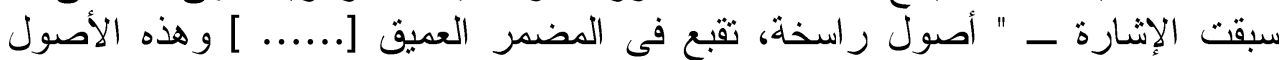

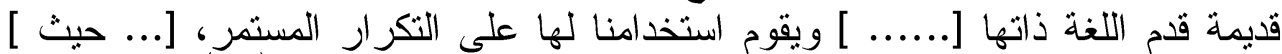

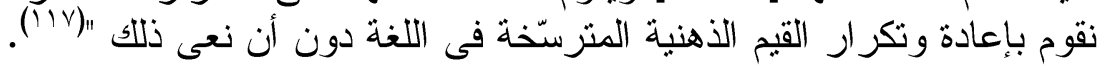

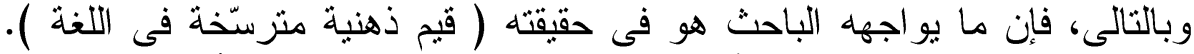

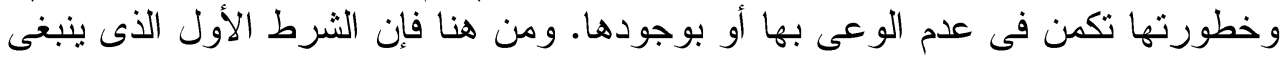

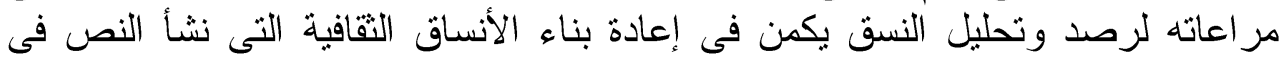

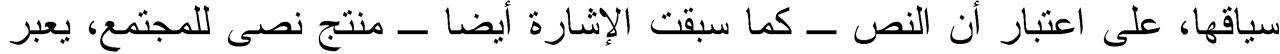

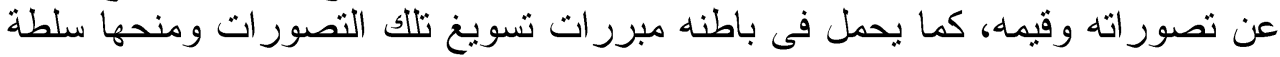

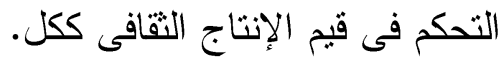

و عملية البناء هذه تتطلب الوقاج الوف عند السياقات العامة للبنى النصية التى ينتمى

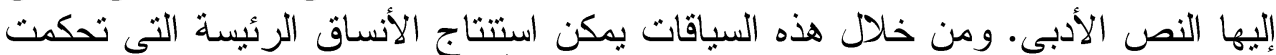

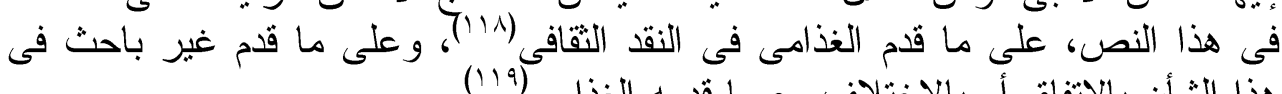

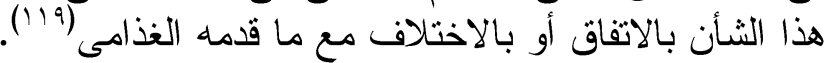

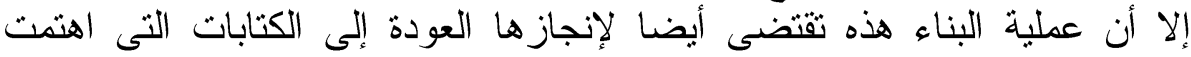

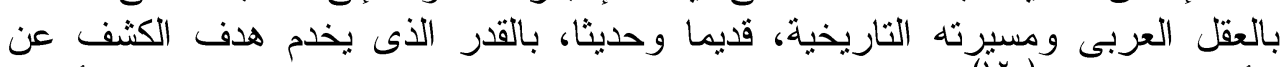

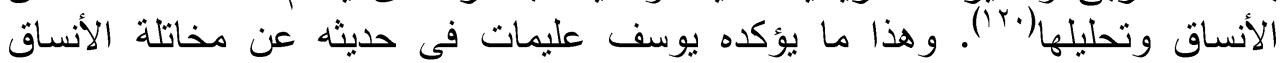

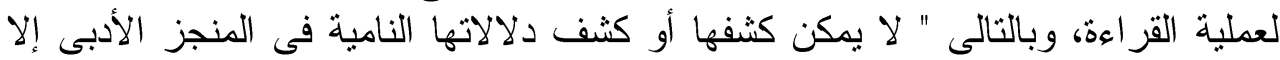

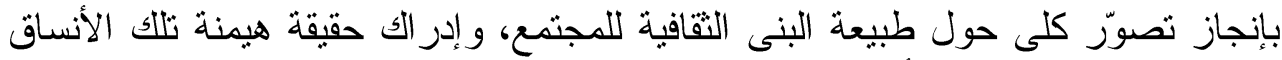

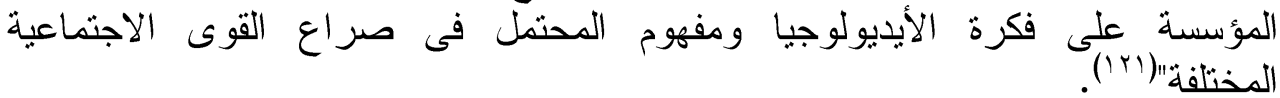

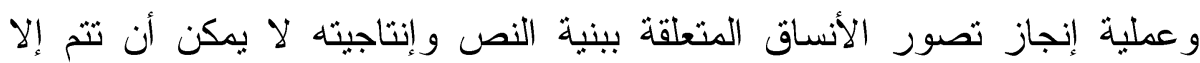

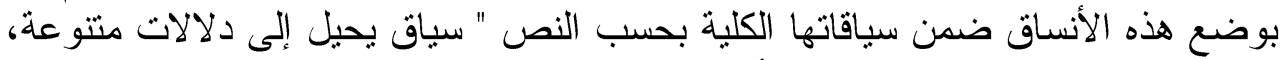

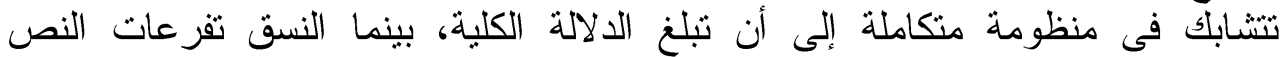

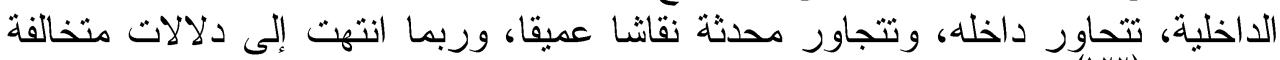

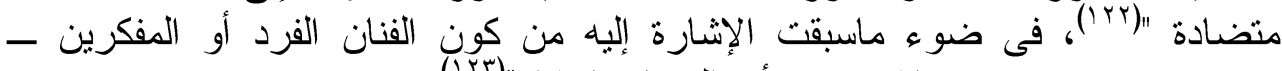

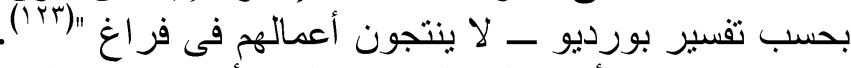

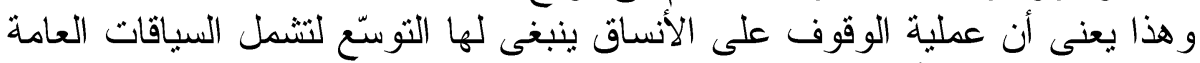

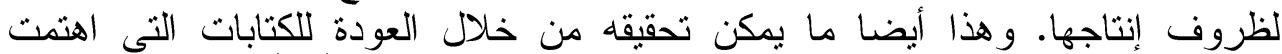

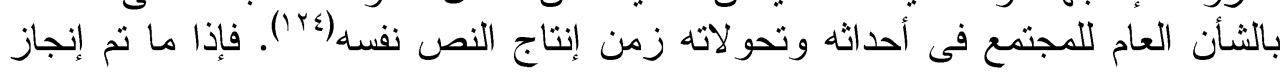


مثل هذا التصور عن الأنساق والسياقات العامة المحيطة بإنتاجية النص وظروف نشأنه

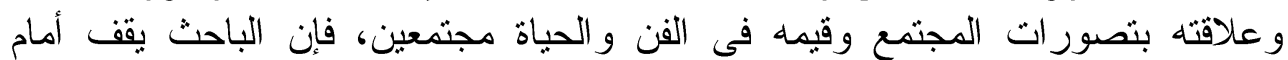

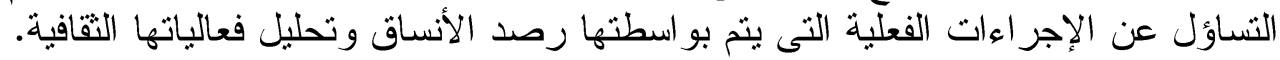

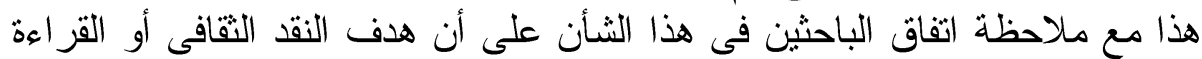

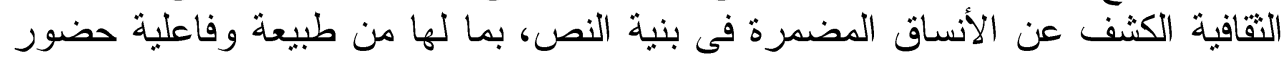

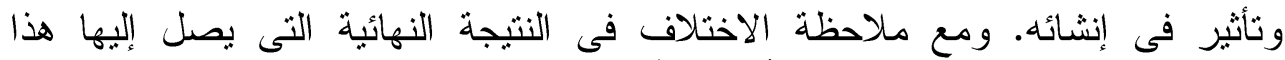

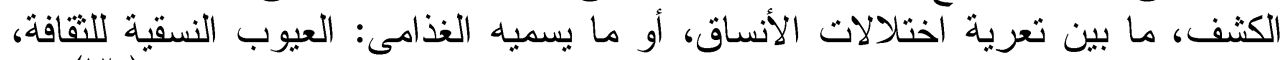

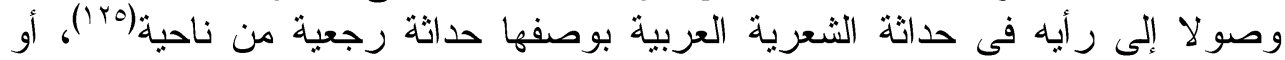

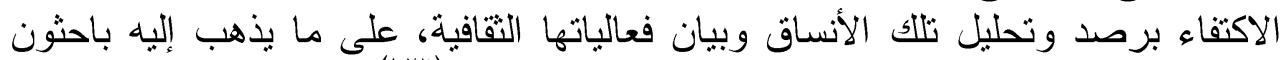

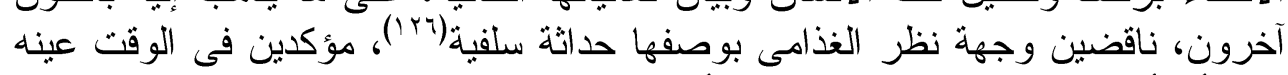

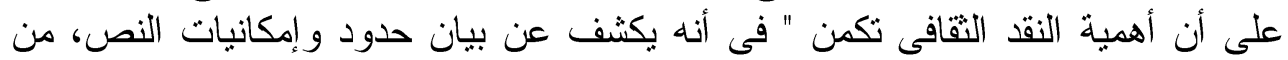

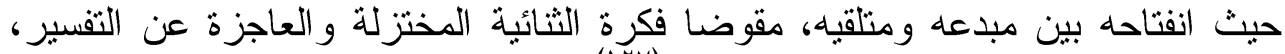

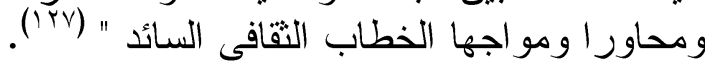

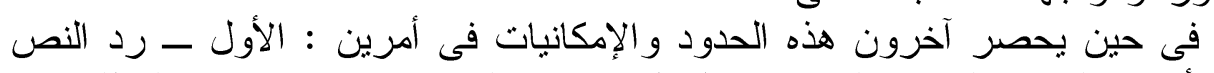

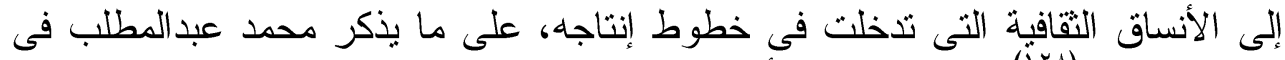

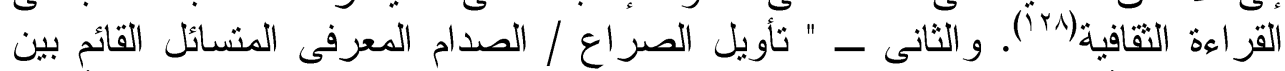

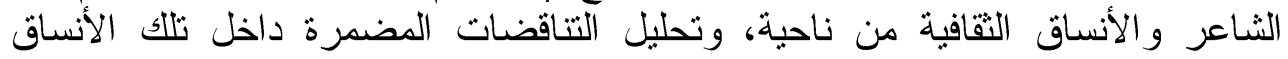

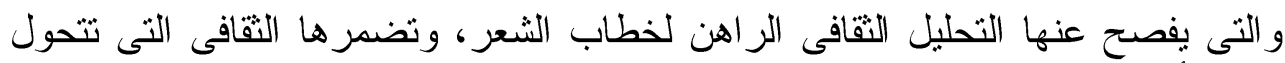

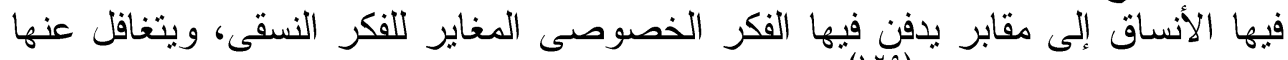

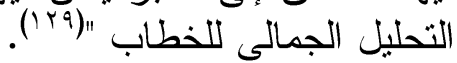

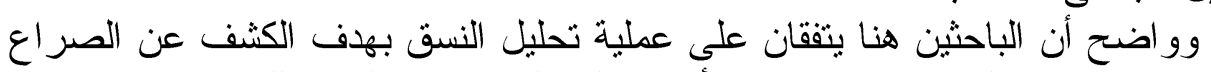

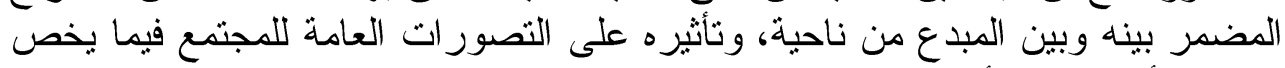

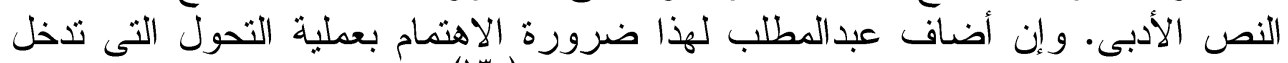

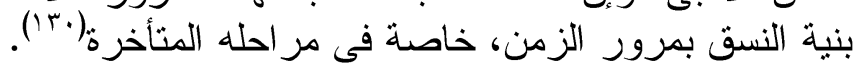

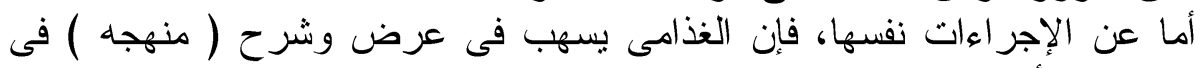

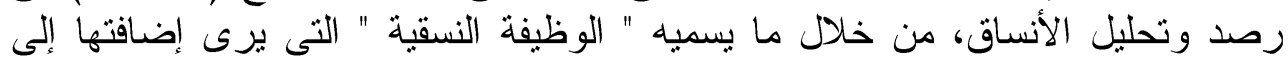

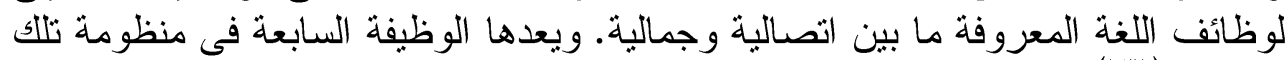

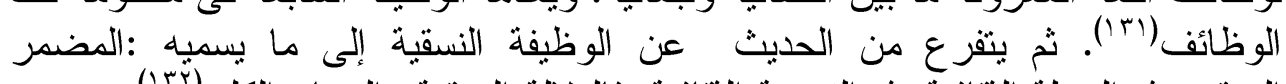

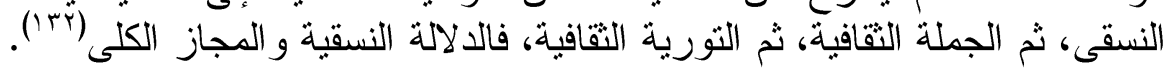

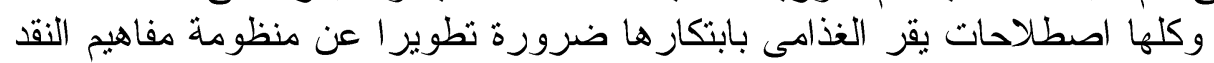

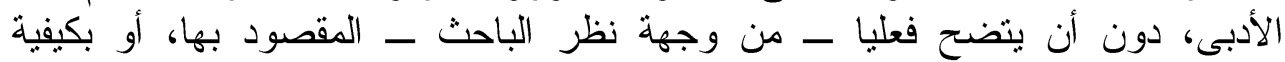

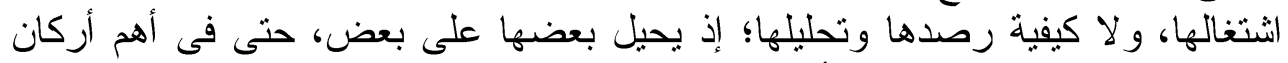

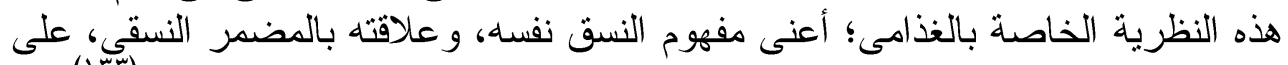

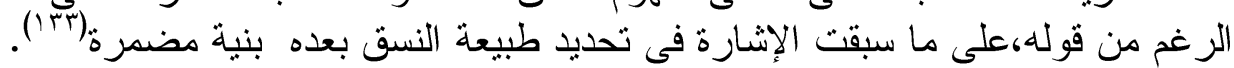

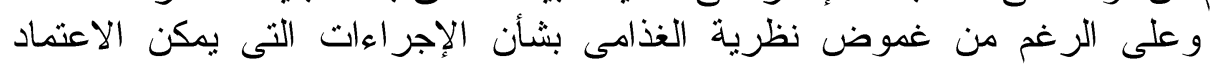

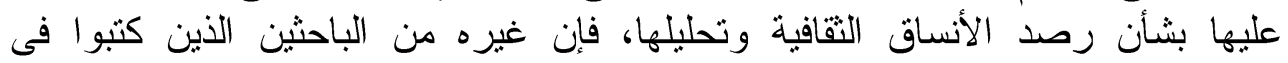

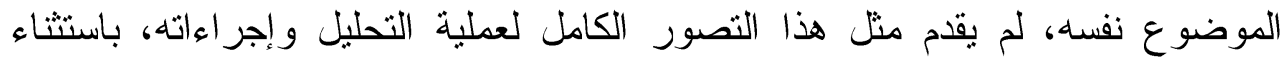
إشار ات بمكن تأويلها على أنحاء شتى. 
ومن أوضح هذه الإشار ات ما قدمه عبدالفتاح يوسف فى قر اءة النص، حيث يقول:

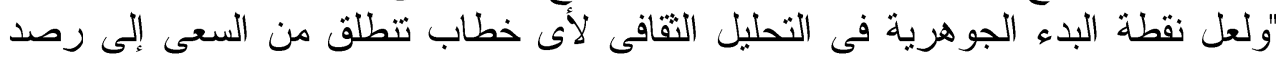

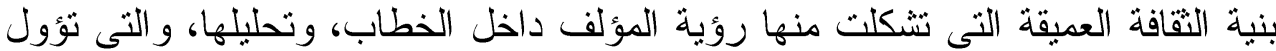

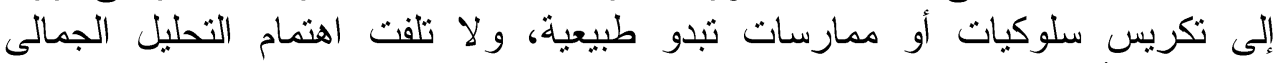

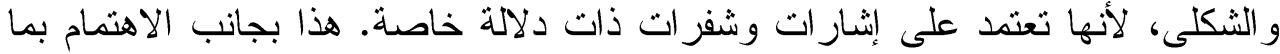

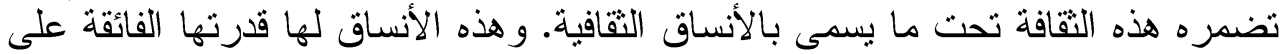

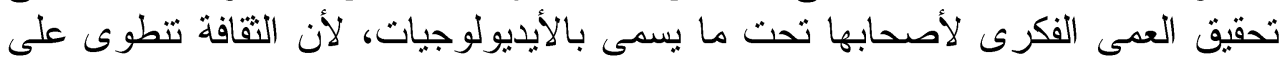

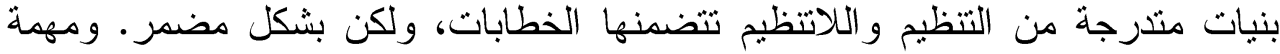

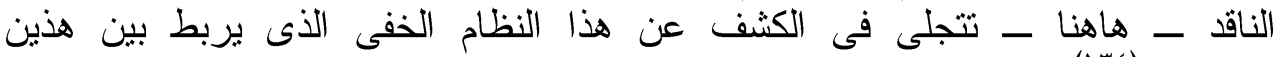

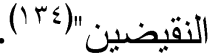

و إثارة الاكتور عبدالفتاح يوسف هنا، لا تخلو من الغوض اليضان أيضا، في تحديدها

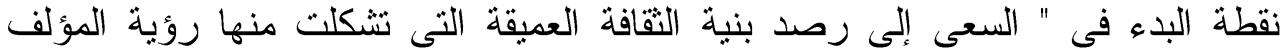

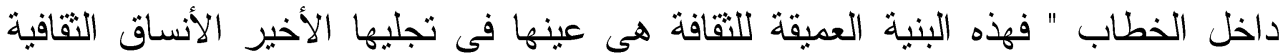

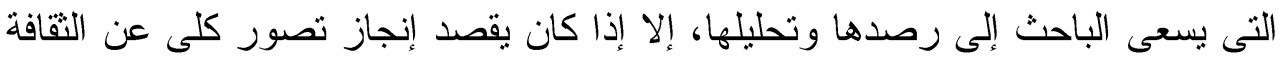

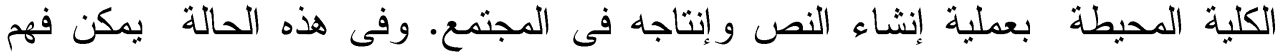

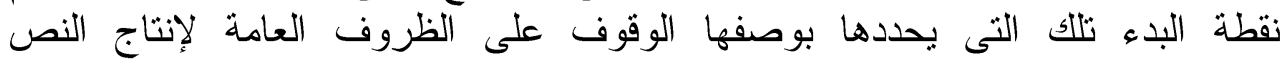

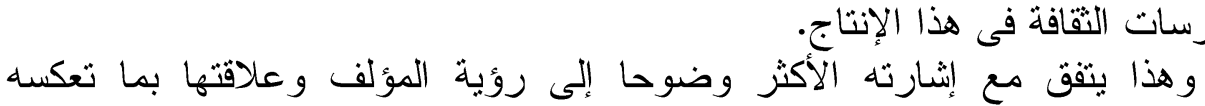

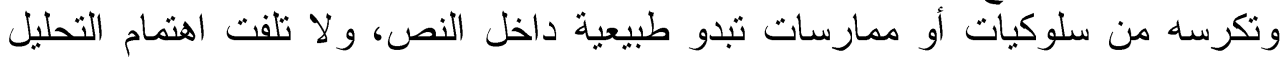

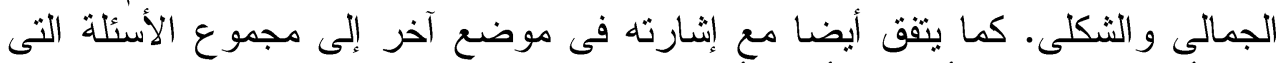

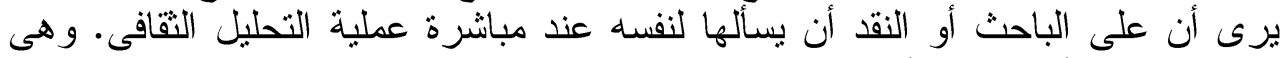

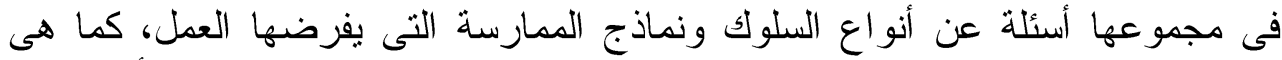

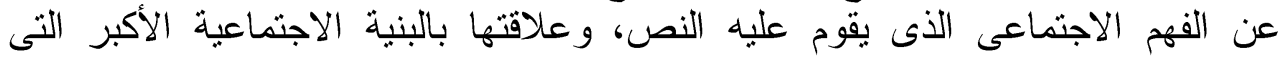

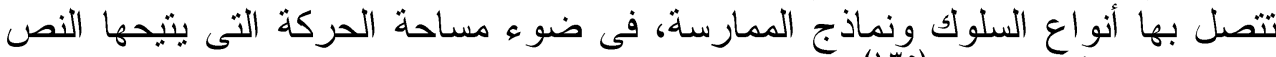

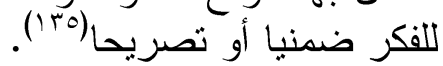

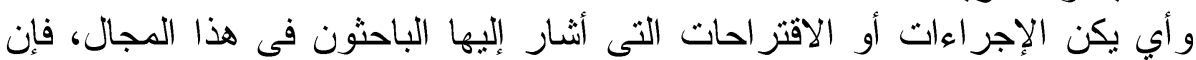

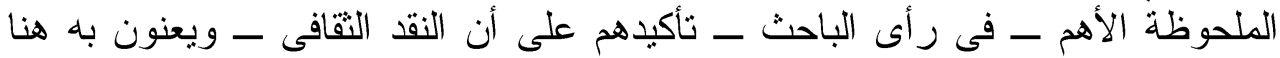

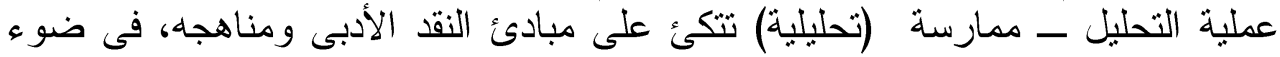

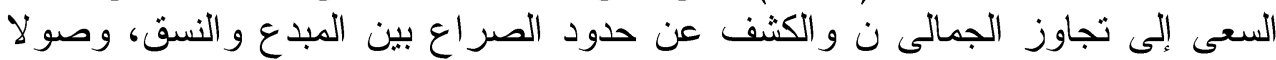

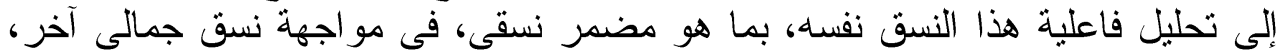
معلن، ومسيطر على ظاهر النص. لنس.

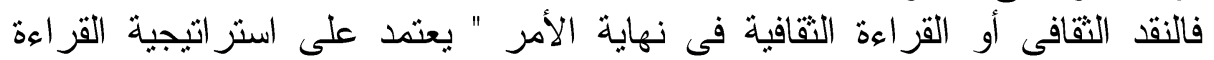

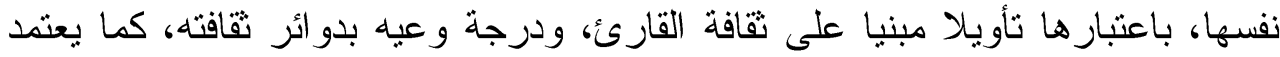

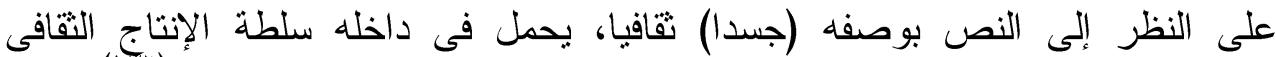

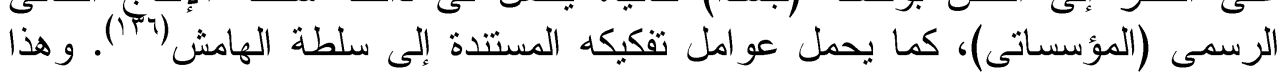

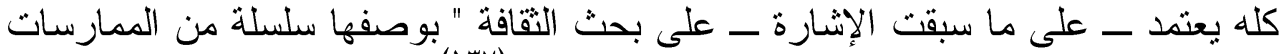

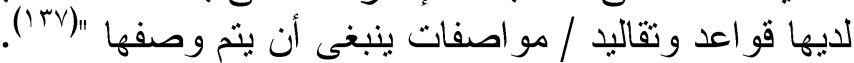

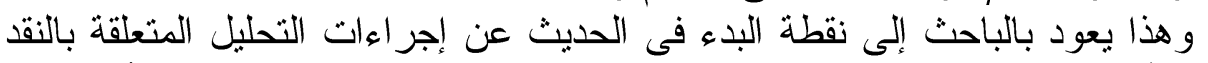

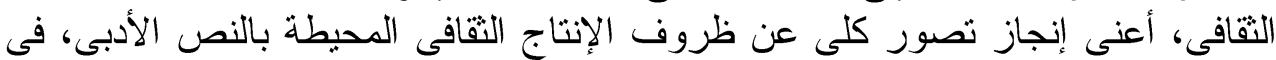
ضوء علاقتها بمفاهيم السلطة و الهامش و المقاومة التى نشأت عن الاهتمام بها الدراسيات الأديات 


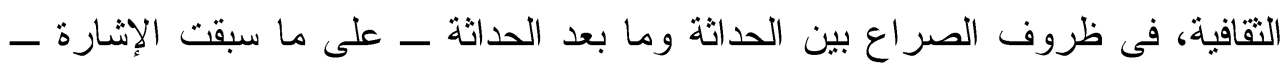

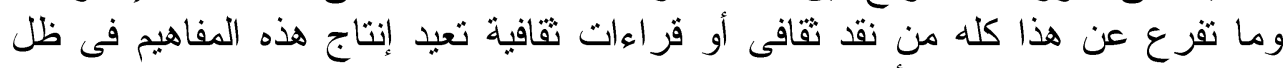

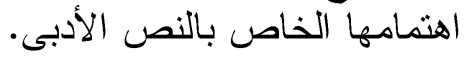
وبالتالى، فسوف بكون عملية الإنجاز هذه هي هوضى موضع التحليل في المبحثين

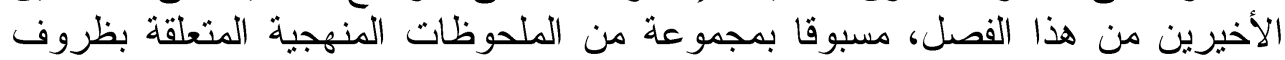

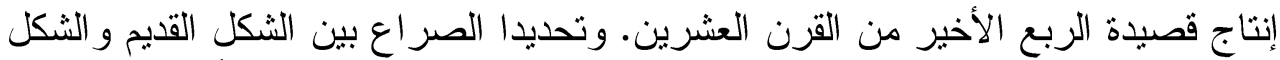

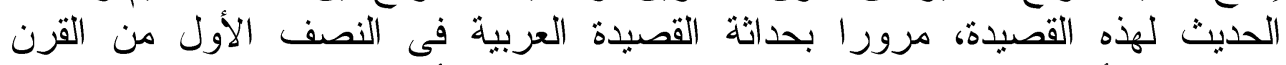

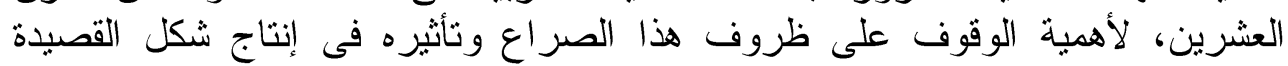

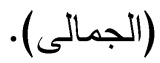

وسوف أعتمد فى هذا بطبيعة الحال على مفاهيم النقد الأدبى - البنيوى وما بعد

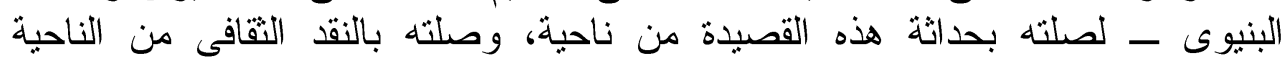

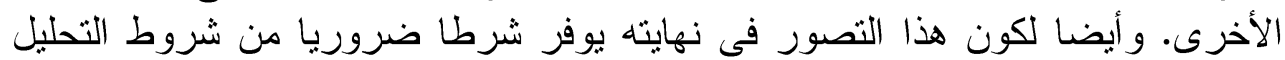

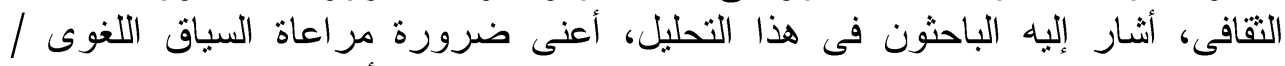

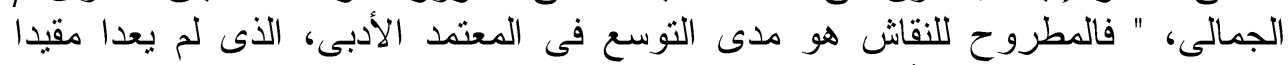

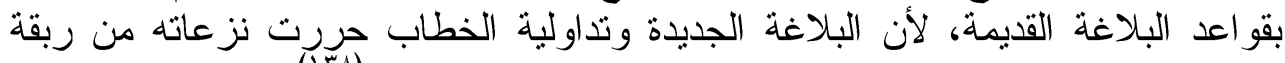

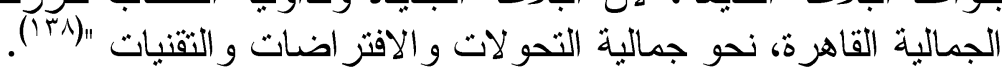

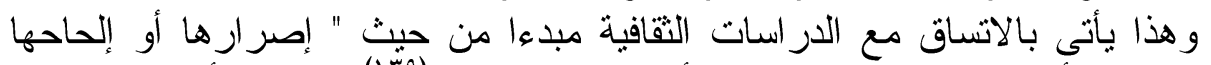

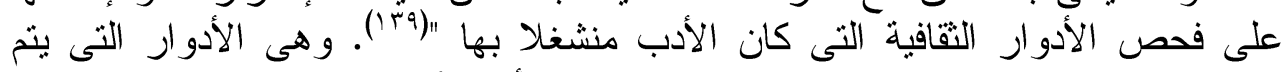

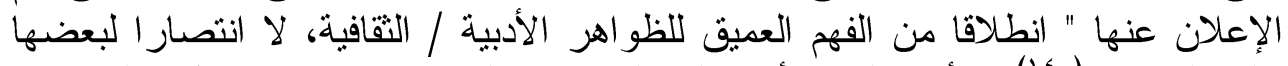

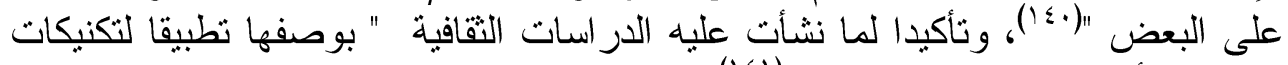

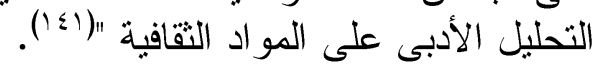

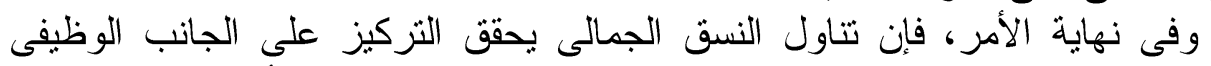

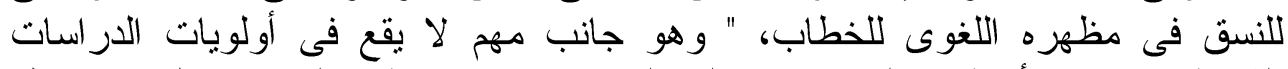

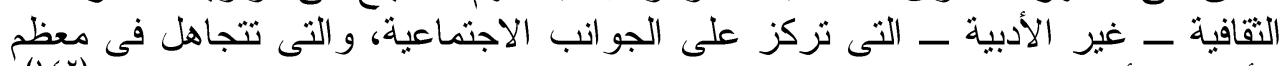

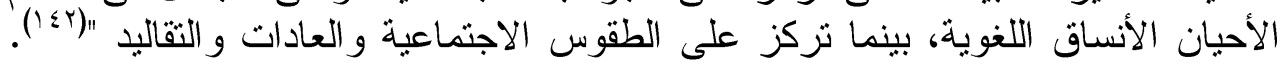

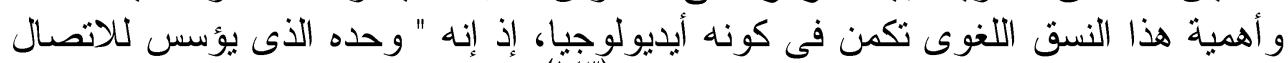

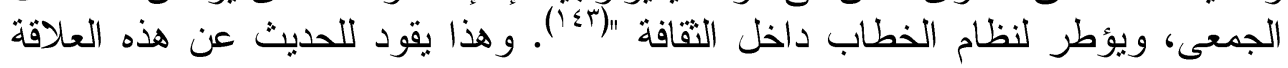
بين الثقافى و الجمالى، من خلافل النسق نفسه الذيى يمثل لب عملية التحليل

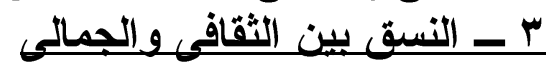

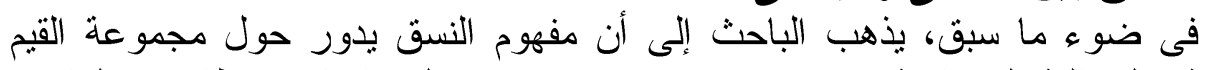

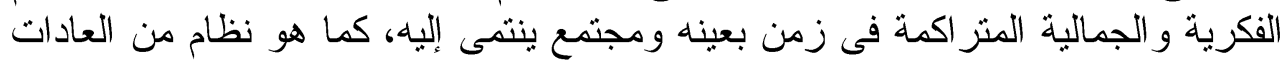

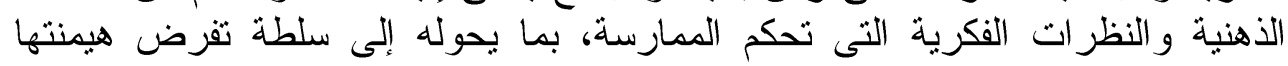

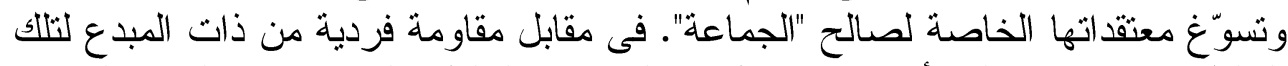

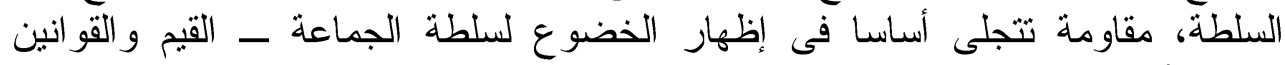

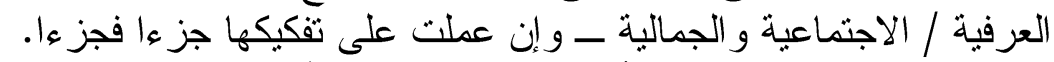

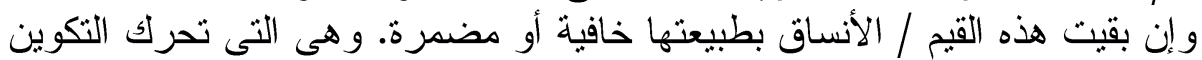

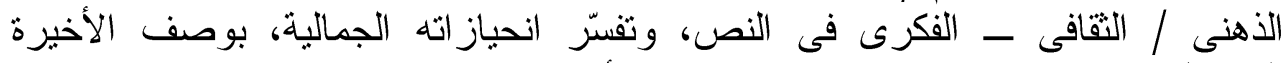

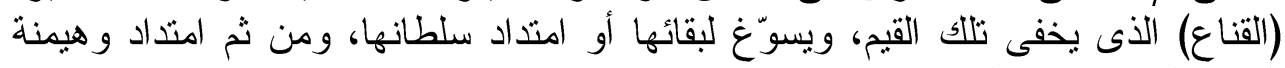


و على هذا النحو، بمكن أن نفه طبيعة التكوين الجمالى فى النص الأدبى، بوصفه

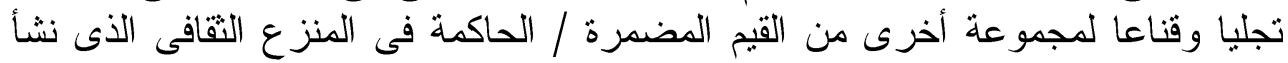

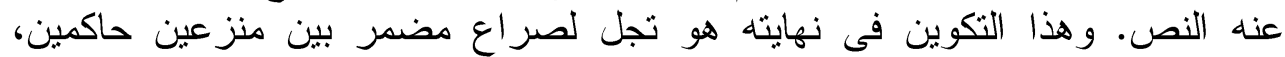

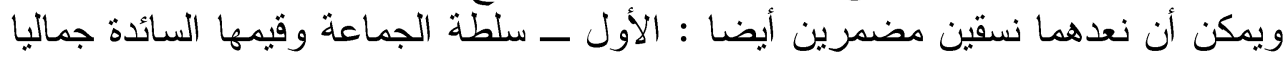

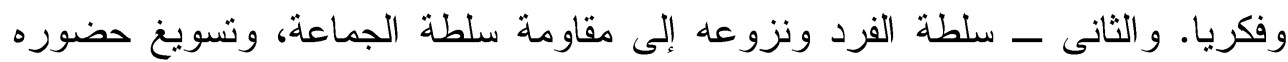
النسقى فى مقابل الجماعة.

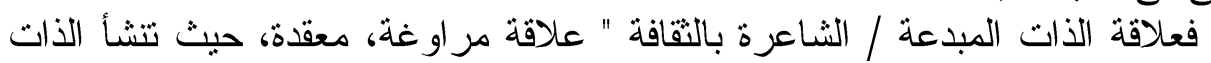

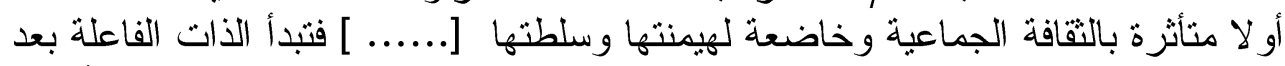

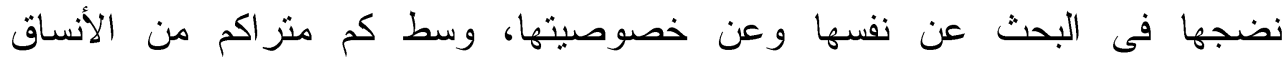

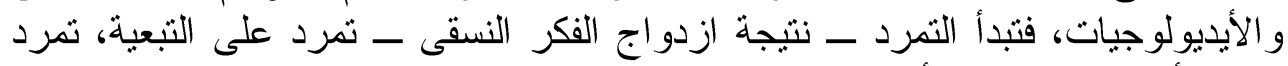

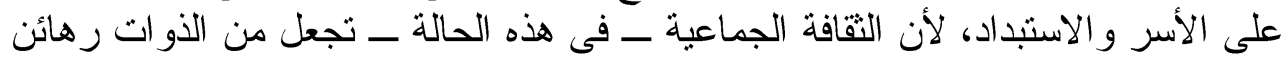

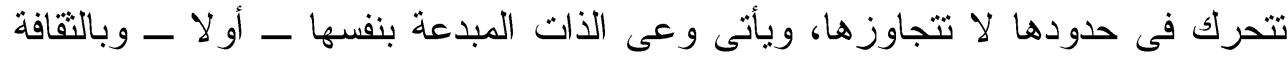

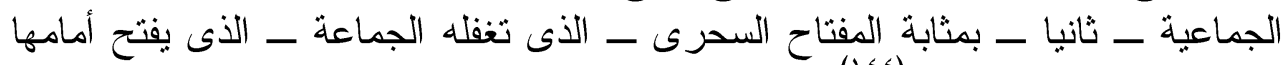

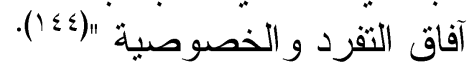

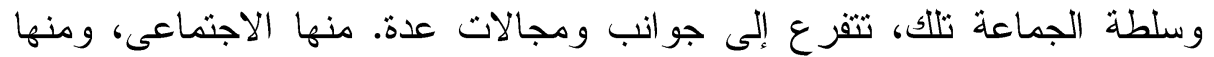

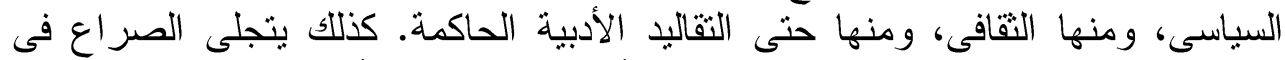

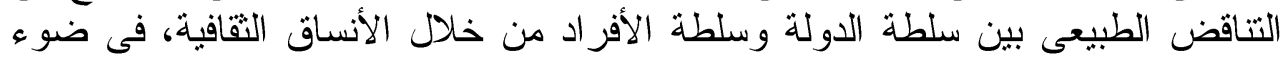

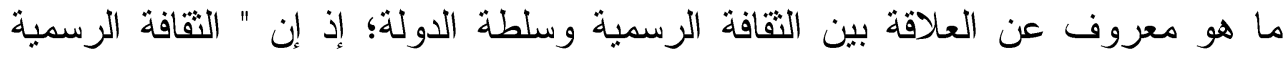

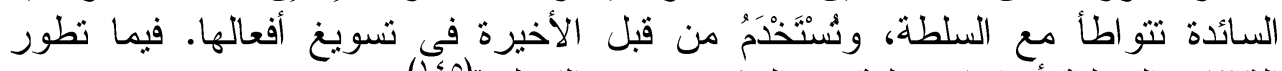

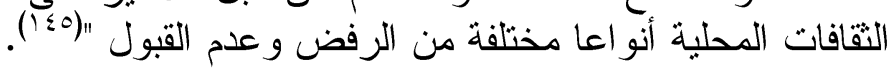

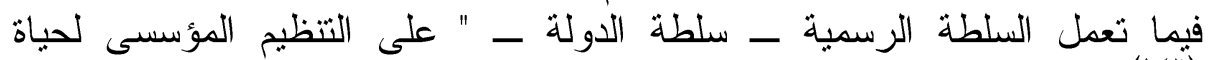

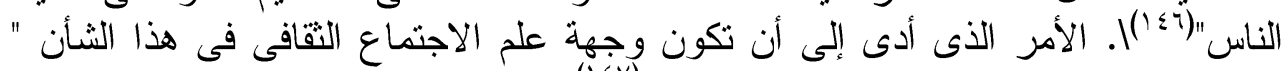

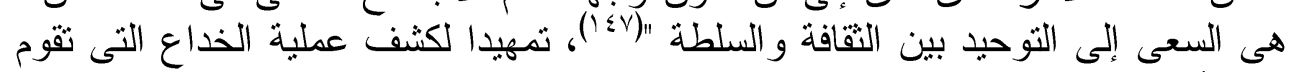
بها الأنساق في هذا الى المجال.

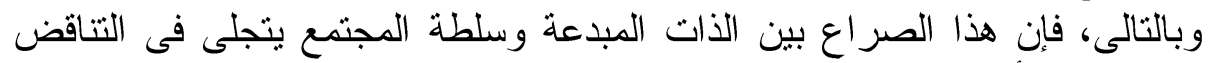

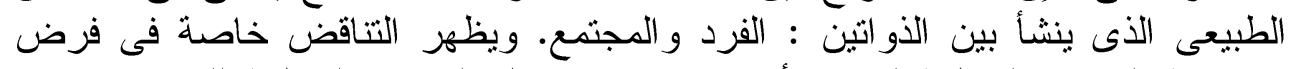

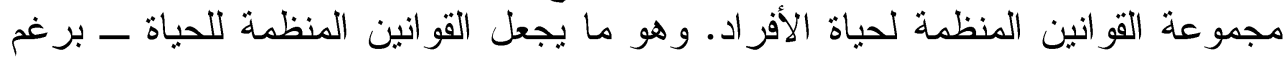

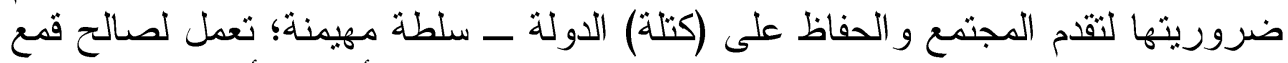

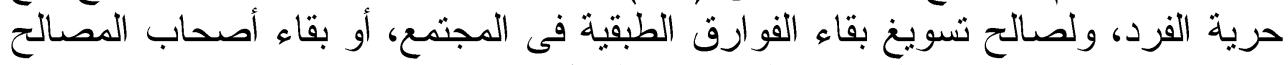

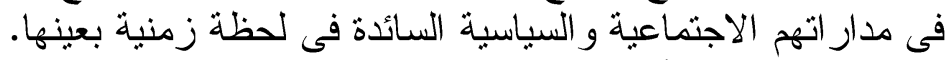

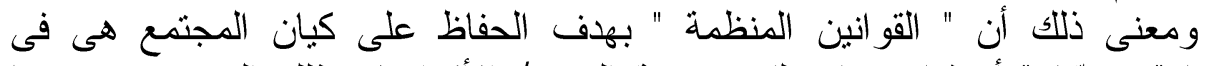

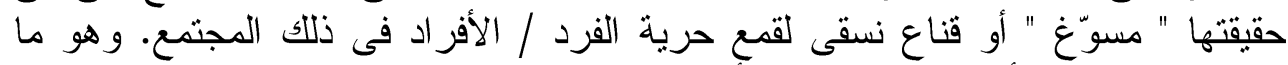

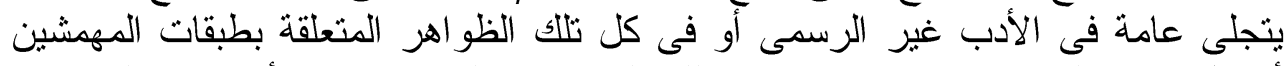

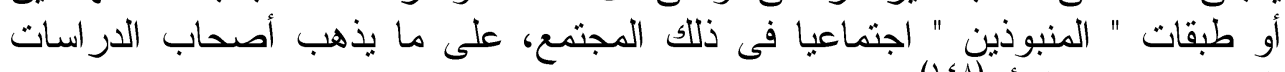

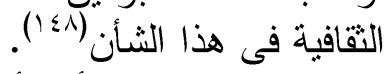

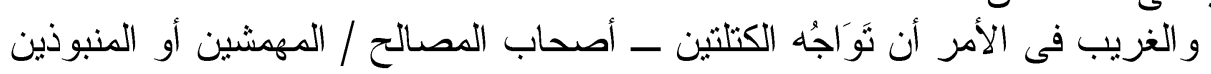

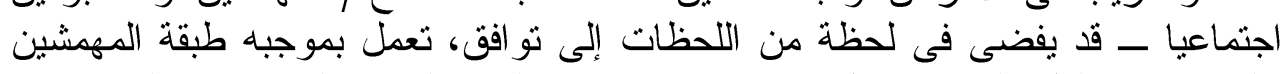

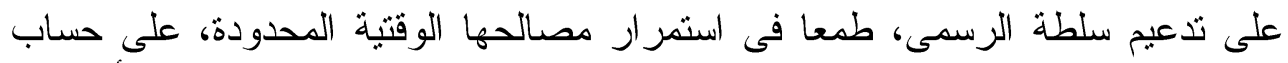

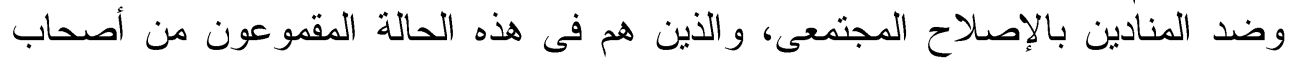


الرؤية الفردية ــ مفكرين، كتاب وشعر اءو... إلخ - الداعون إلى التمرد على القو انين

ولهذا، فإن تحليل العنصر النسقى ينبغى له ألها يسرف في تبنى منظور تسويغ

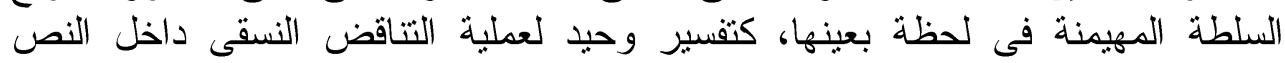
الو احد، تجنبا للوقوع فى تقسير أحادى لكل الظو اهر الأدبية بتجليها النصى.

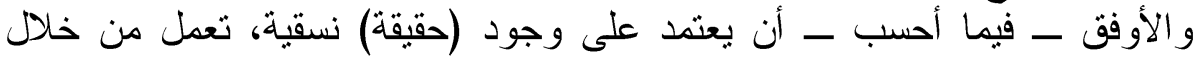

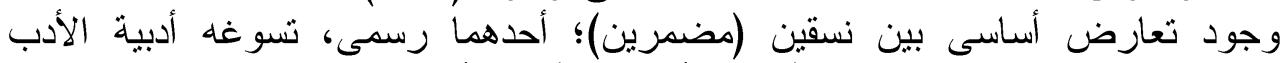

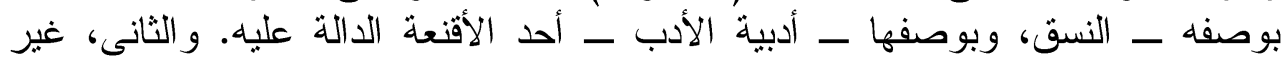

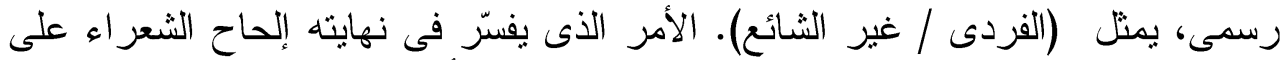

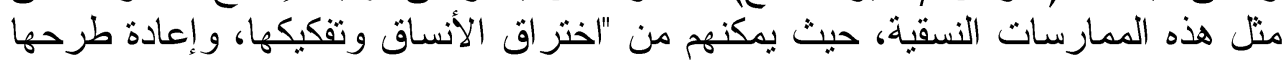

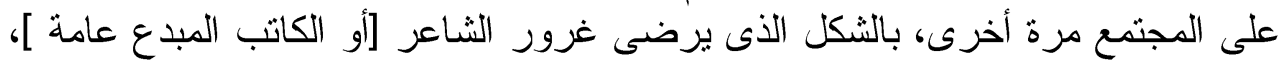
ولا تعترض عليه الجماعة. فهذه الممارسات تنطوى على ثنائية (الإحلال و الإبدال)،

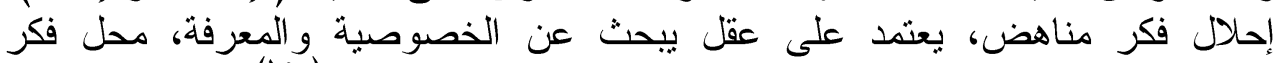

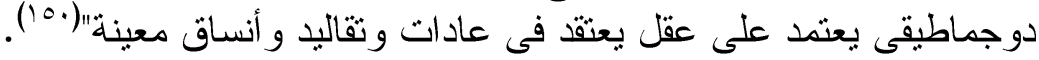

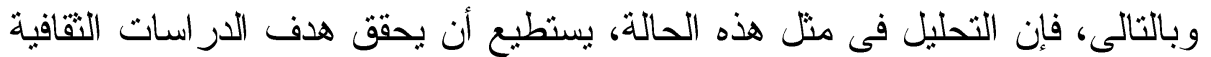

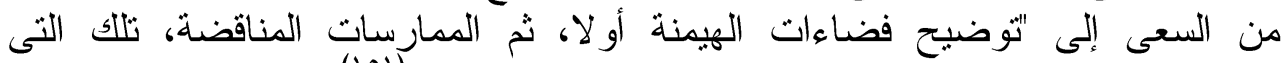

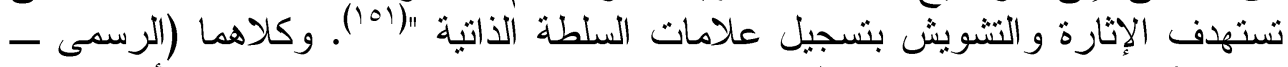

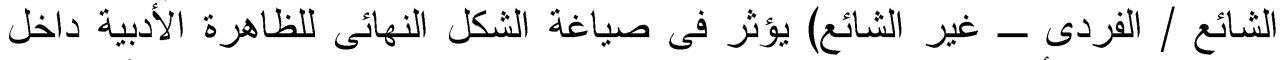

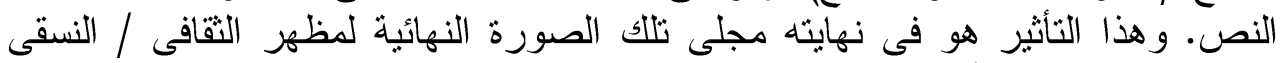
كخطاب وشكل، كما أنه مجلى التحول النسقى فئى فلى القيم الحاكمة المنشئة.

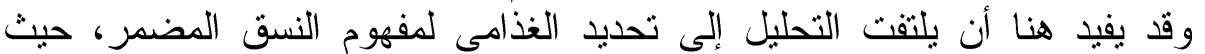

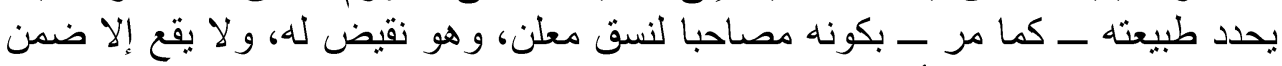

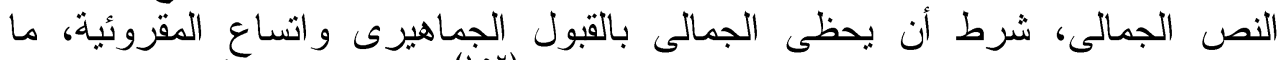

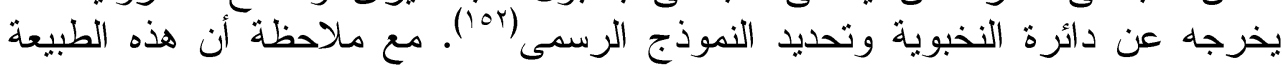

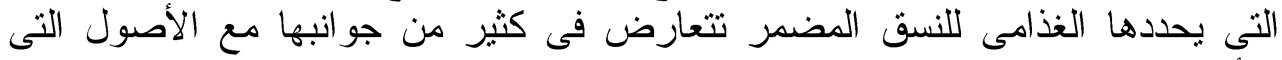

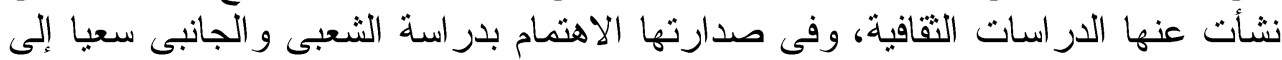
الكثف عن خصائصده المميزة.

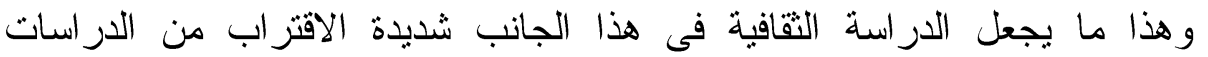

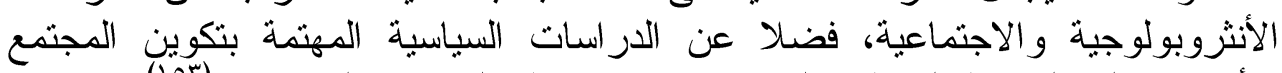

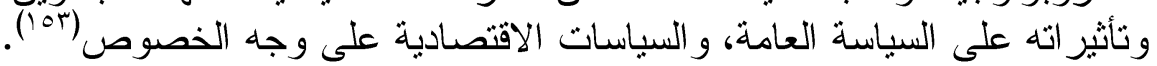

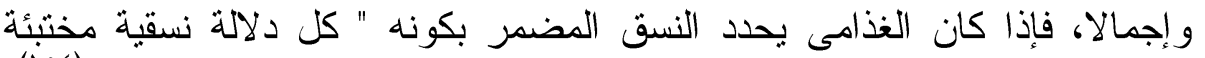

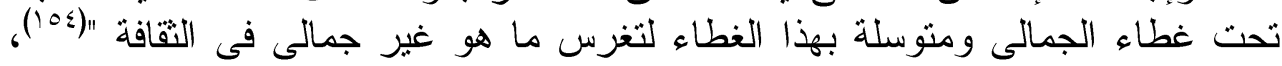

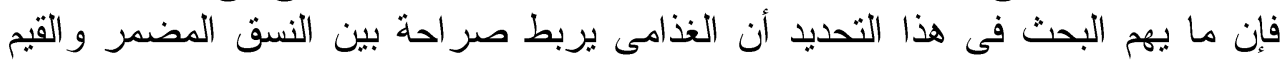
العامة للمجتمع، " مثل قيم الحرية و الاعتر اف بالآخر وتقدير المهمش و المؤنث و العدالة التهن

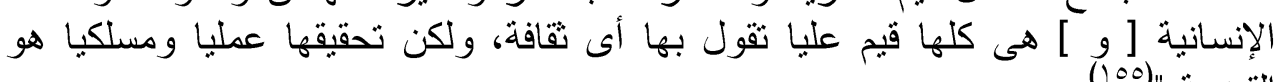

وبغض النظر عن كون الغذامى يرى أن دراسة النسق المضمر من خلال دراسة

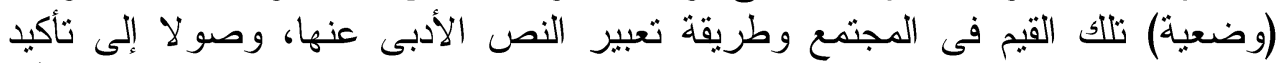

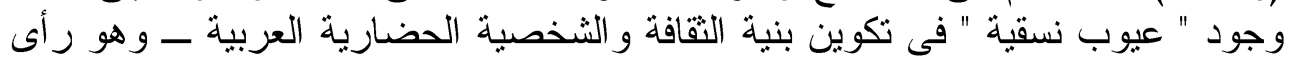


أشرت قبل قليل إلى عدم قبوله لأسباب ذكرتها فى إثارتى ـ فإن هذا الربط الصريح بين

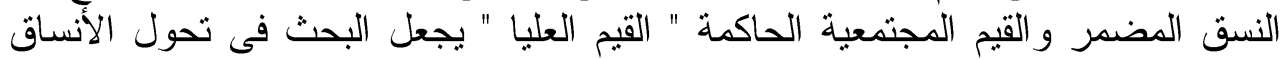

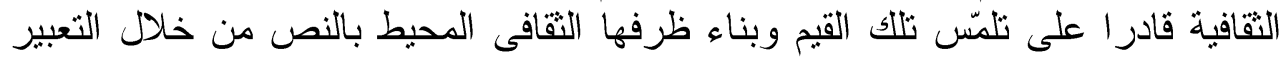

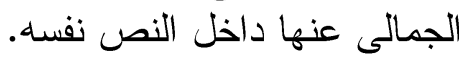

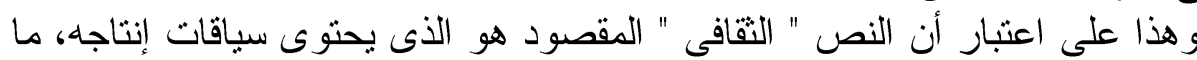

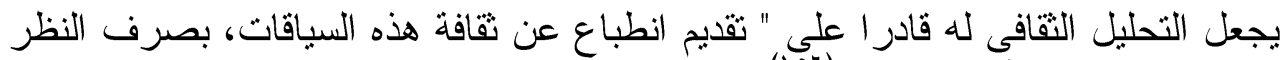

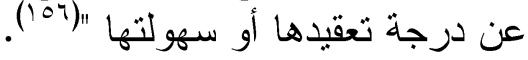

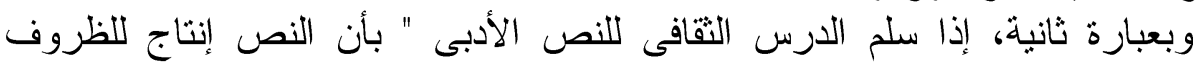

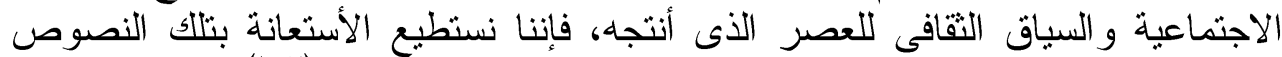

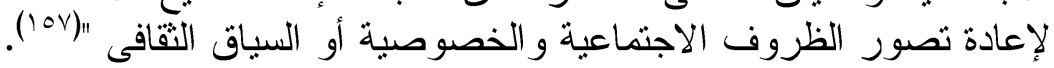

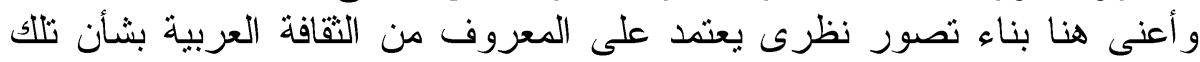

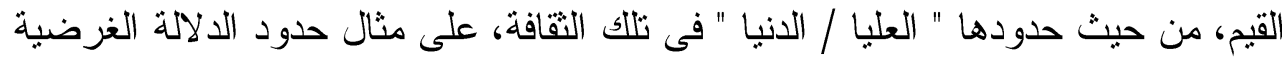

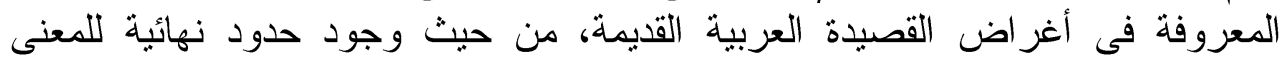

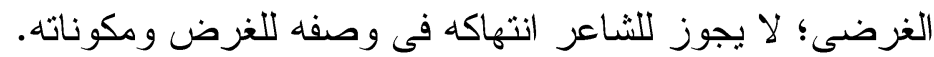

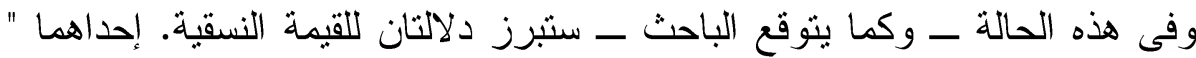

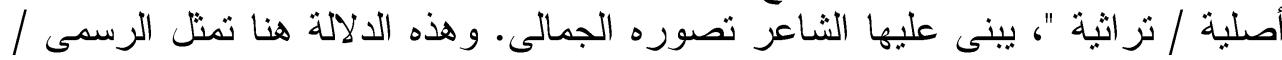

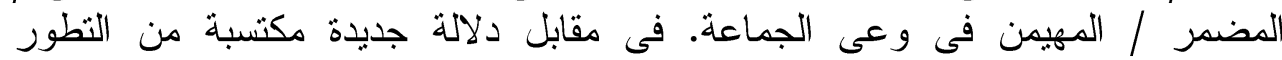

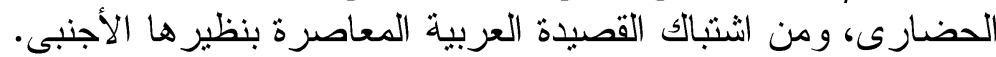

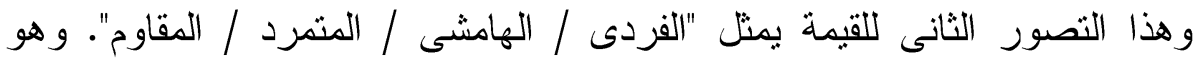

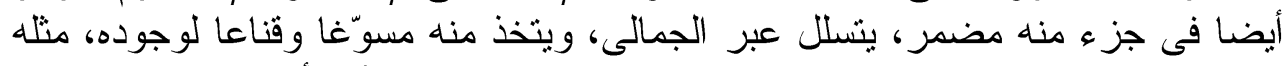

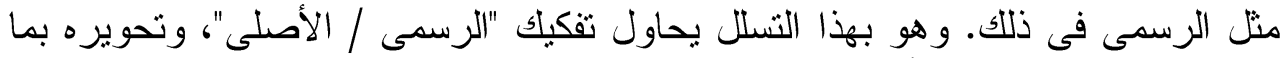

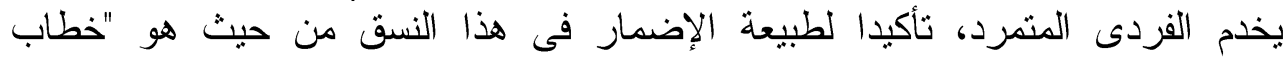

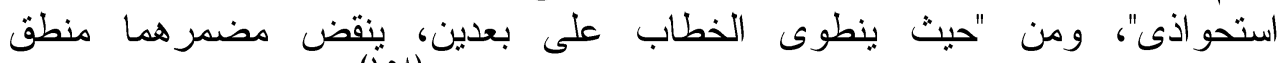

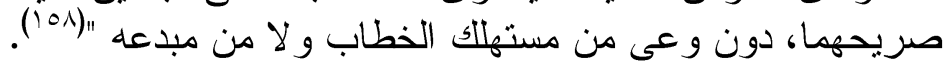




\section{Abstract \\ The Concept of Pattern in Criticism and Cultural Studies By Mohamed El Sanosi Omar EI Twaty}

The concept of pattern is one of the key notions on which cultural criticism has relied in its analysis of literary texts. The concept is derived from social analysis in this area of study. However, it is primarily related to the total cultural studies which opened broad ways in this regard. That is to say, they deal with numerous phenomena using specially significant terms, though these terms might be linked to different sources. Some of these sources are attributable to literary criticism which has been influential in this regard through the writings of its notable figures which have gone beyond the limits of literary texts to the horizons of political, economic, social, and cultural phenomena in general.

As to the literary text in particular, the most obvious remark is related to the constant interrelatedness between cultural studies, being the general field that allows for interaction between all these areas on the one hand, and literary criticism on the other hand as one of the main sources that influence the emergence of cultural studies. Accordingly, cultural criticism gives rise to controversy over its topics, origins, methodologies, and relations with cultural studies and literary criticism.

Due to the lack of clarity in the concept of pattern in such writings despite the fact that it has been intensely discussed by them, it is necessary to investigate this concept and clarify its different relations with the founding sources. This aims at determining the nature of this concept and its implications in literary texts.

Thus, I am tackling the concept of pattern in the light of its relations with cultural and literary criticisms as shown in its links with the origins of these two areas in cultural studies.

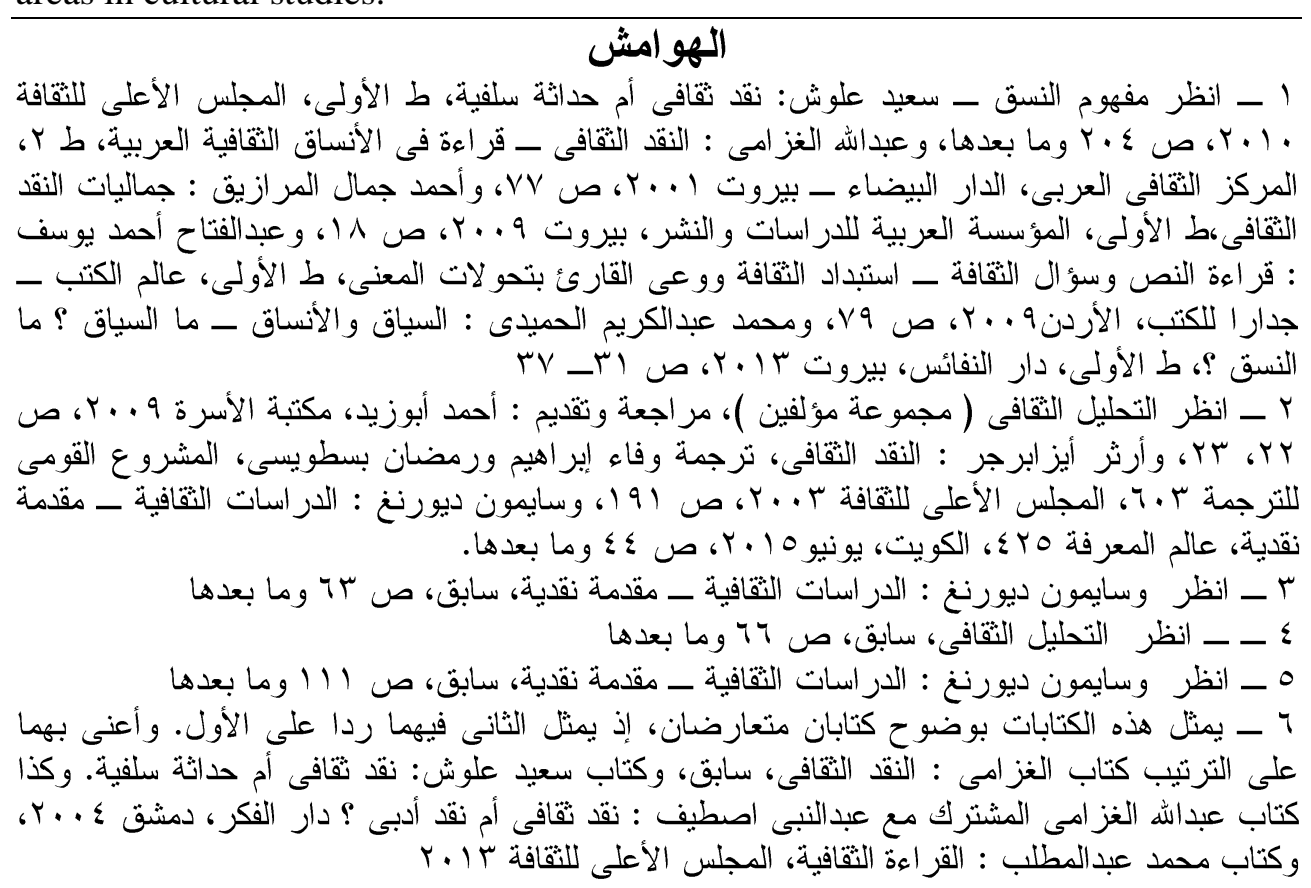




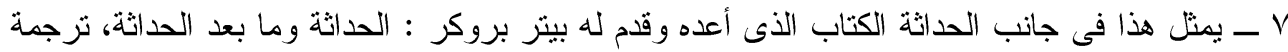

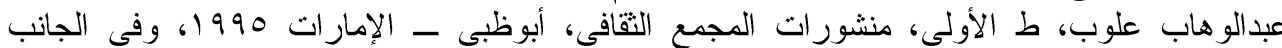

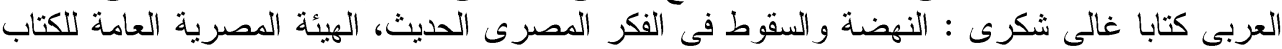

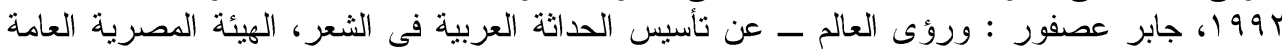

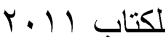

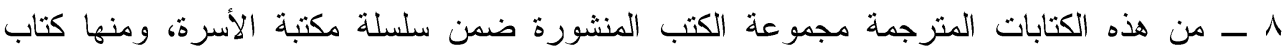

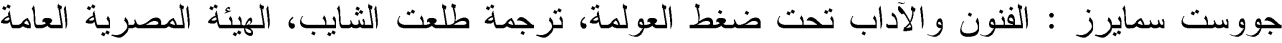

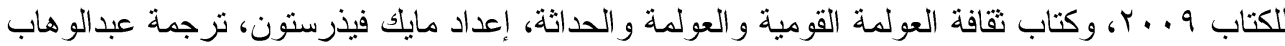

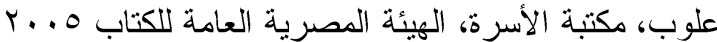

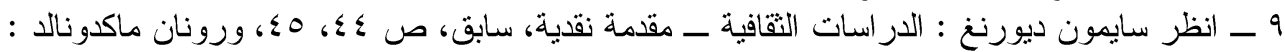

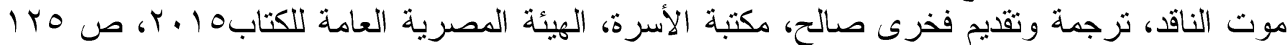

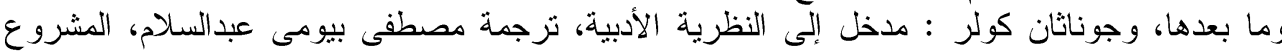

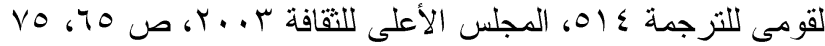

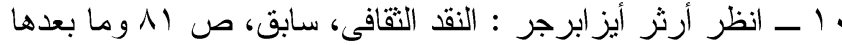

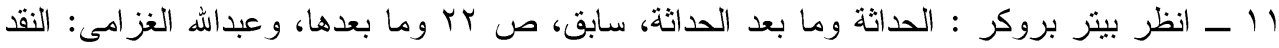

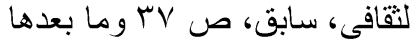

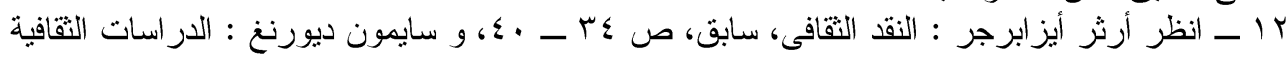

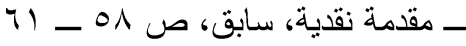

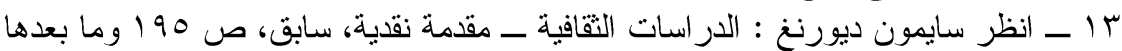

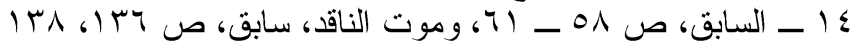

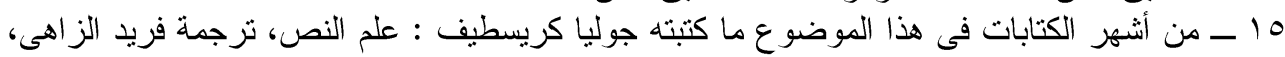

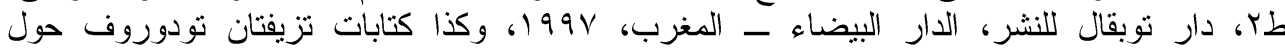

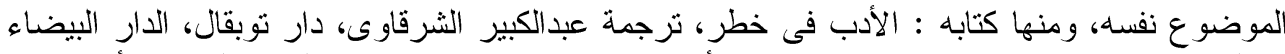

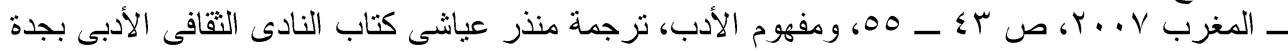

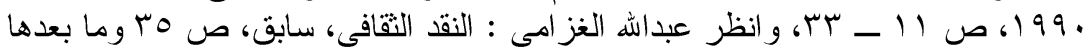

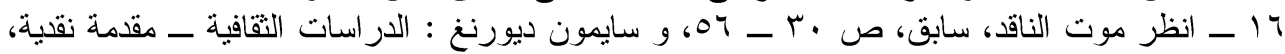

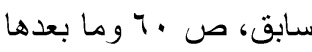

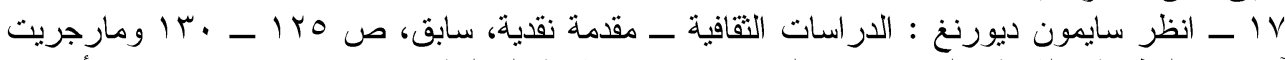

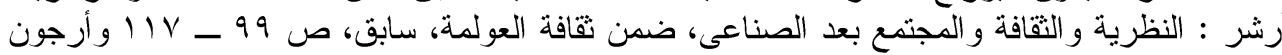

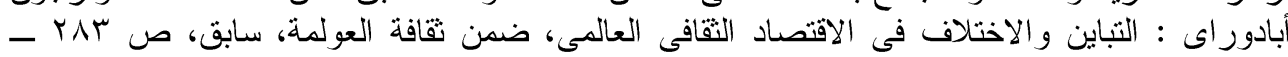
rq7

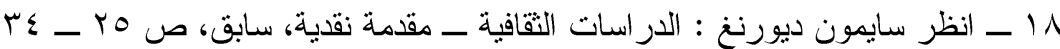

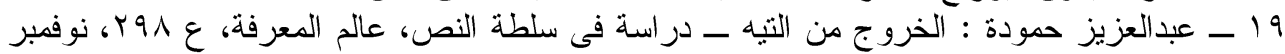

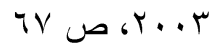

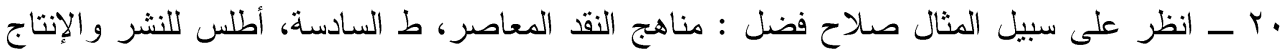

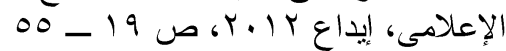

\section{GLEENBOTT , STEPHEN (1995)CULTURE IN}

$\mathrm{N} \quad-\quad \mathrm{l}$

LENTRICCHIAFRANKANDLONDEN ; THEUNIVERSITY OF CHICAGO PRESS PP242 - 241,

A. A ا ( ك

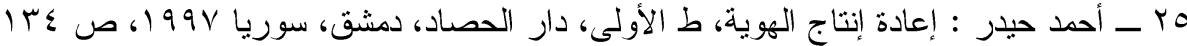

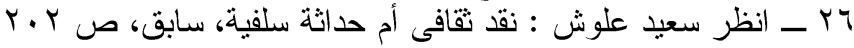

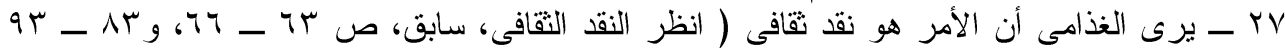

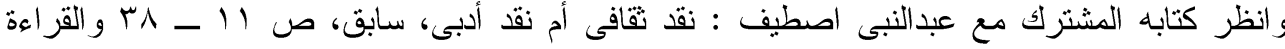
النقافية، سابق، ص 99 ( وما بعدها 


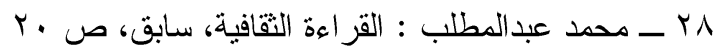

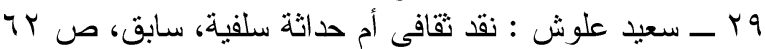

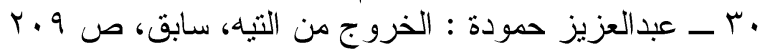

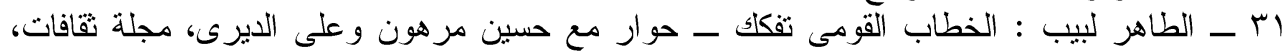

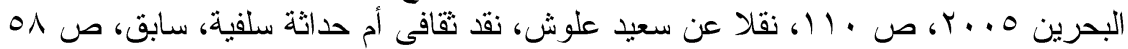

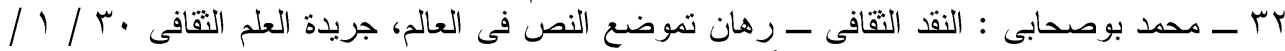

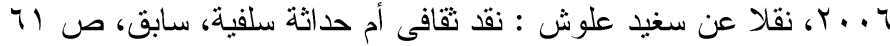

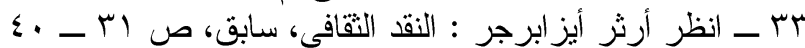

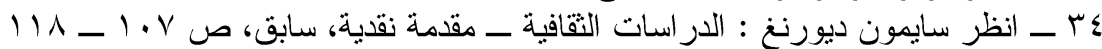

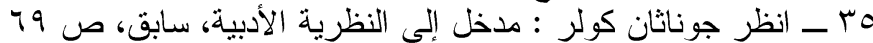

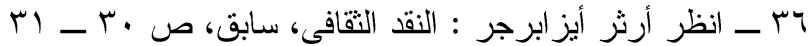

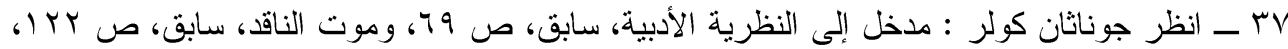

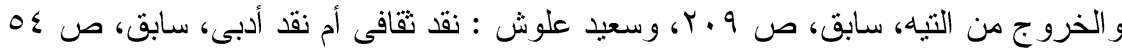

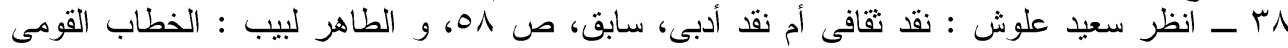

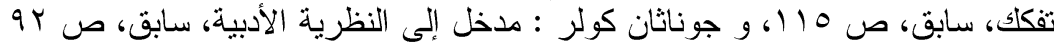

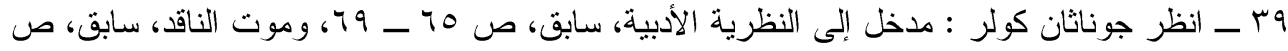

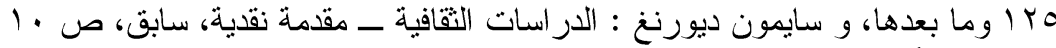

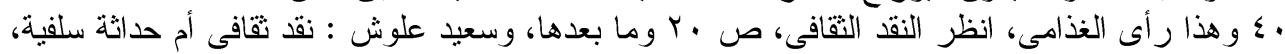

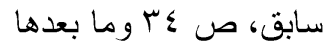

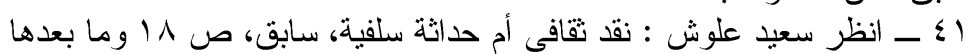

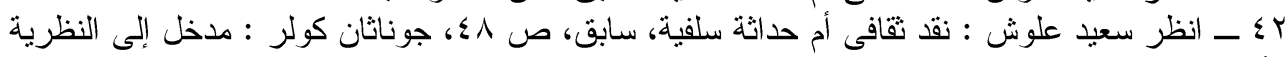

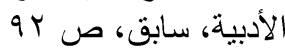

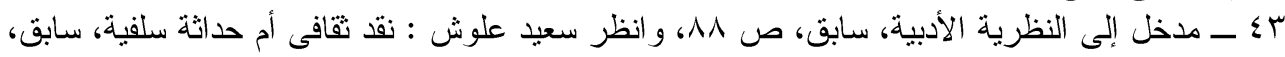
ص

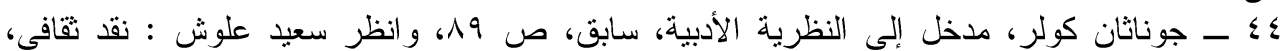

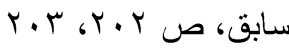

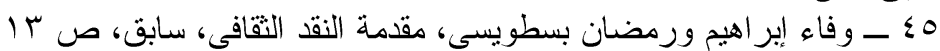
Y

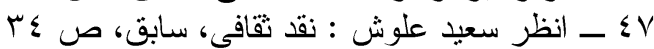

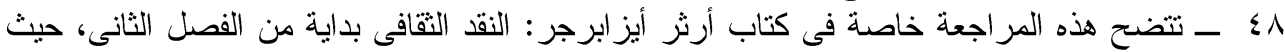

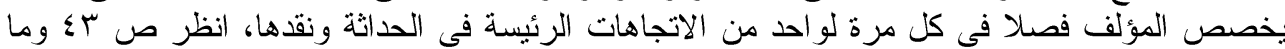

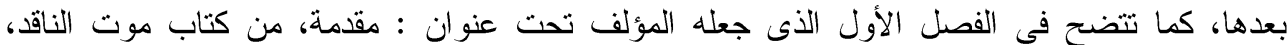
سابق، ص صدا، كمان 10

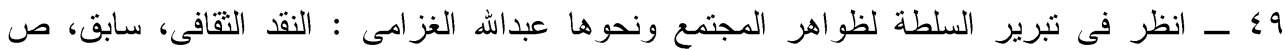

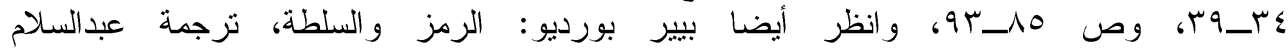

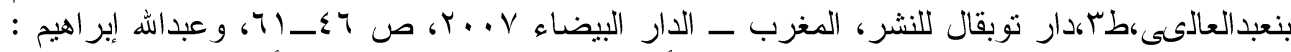

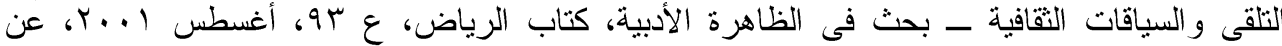

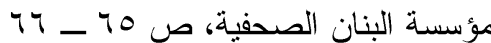

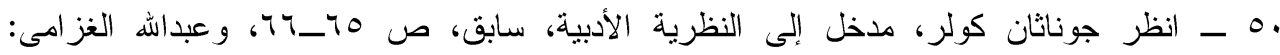

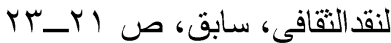

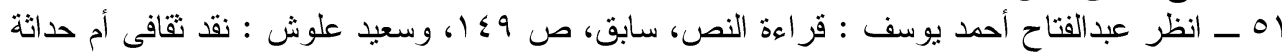

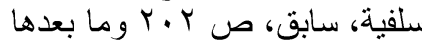

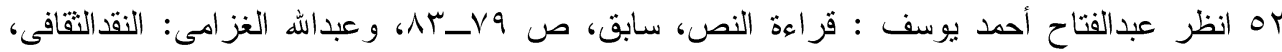

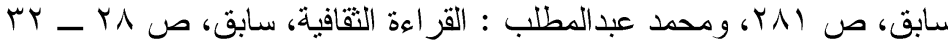

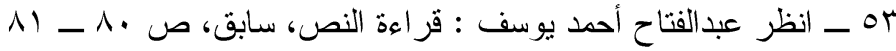


؟ه ـ و عبدالله الغز امى: النقدالثقافى، سابق، ص وVV، عبدالفتاح أحمد يوسف : قراءة النص، سابق، ص

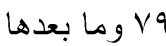

هo - انظر بيتر بروكر : الحداثة وما بعد الحداثة، سابق، ص دب وما بعدها، وعبداله الغزامى:

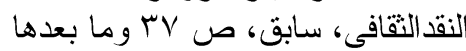

و

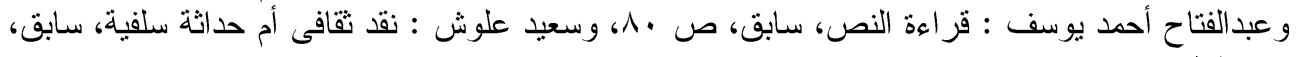
ص ص

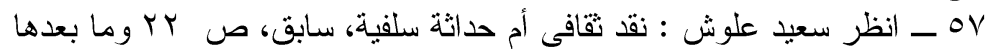

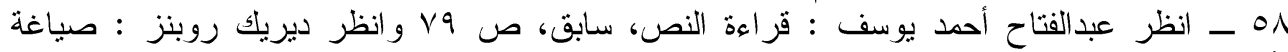

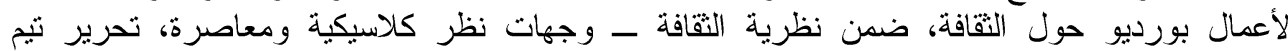

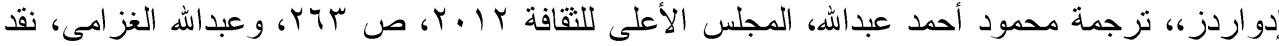

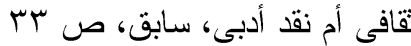

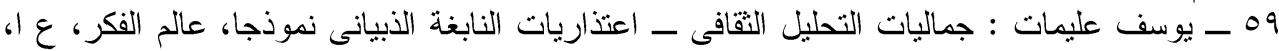

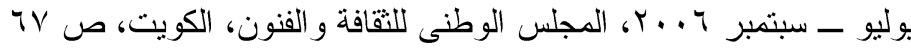

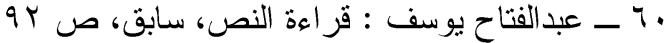

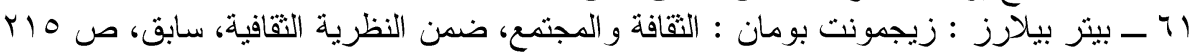

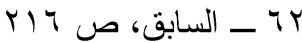

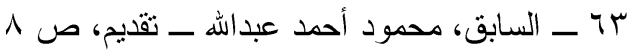

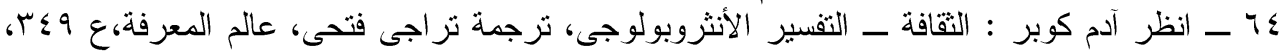

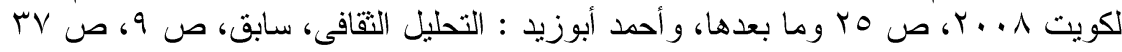

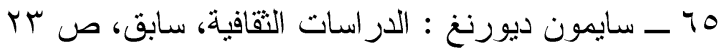

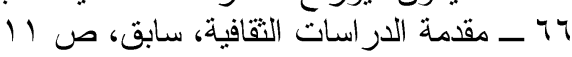

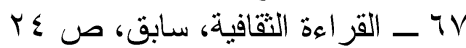
11 19 ـ 99

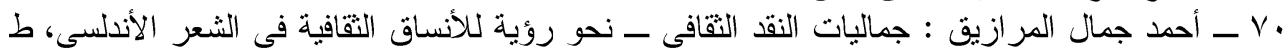

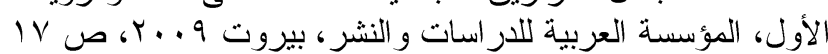

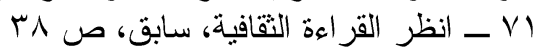

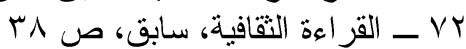
L

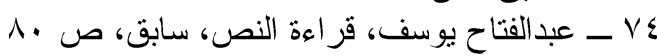
1. ro

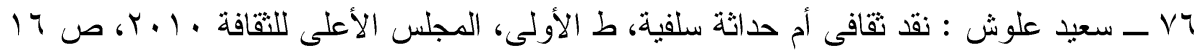

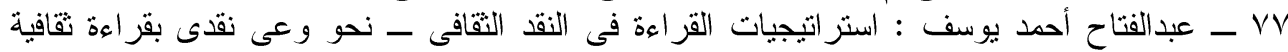

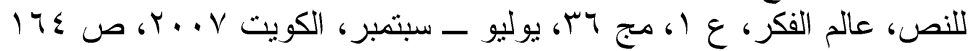

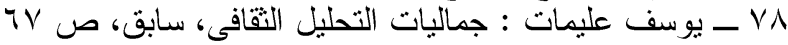

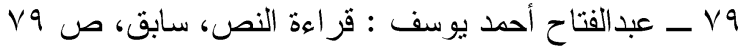

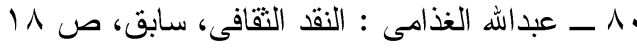
VV السابق،

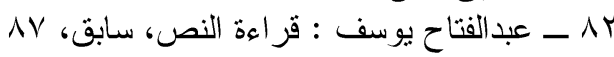

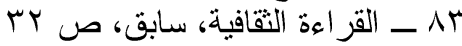

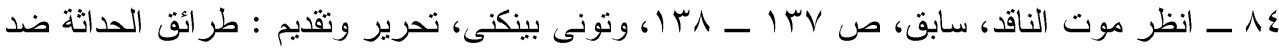

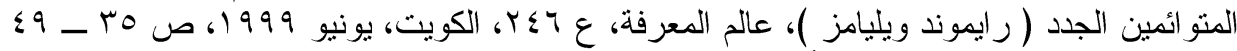

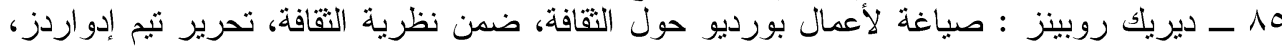

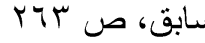

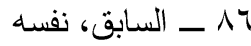


N ـ التعريف لفوكو، نقلا عن أحمد أبو زيد : المدخل إلى البنائية، المركز القومى للبحوث الاجتماعية

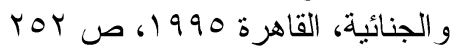

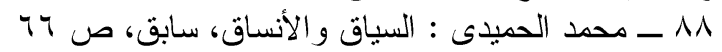

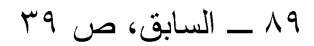

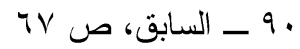

IIV V

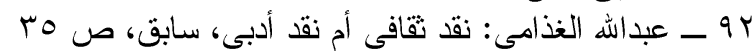

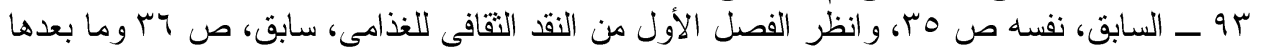

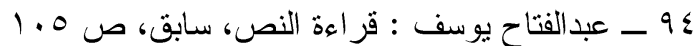

V9 90

90 9 97

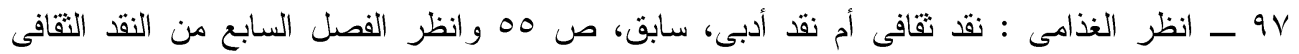

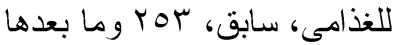

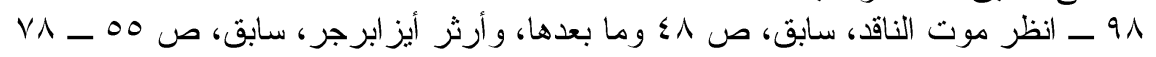
NV 99

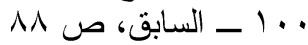

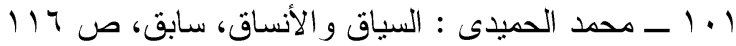

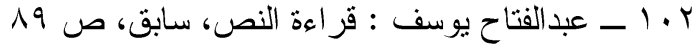

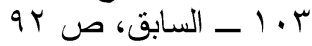

ك

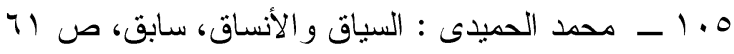

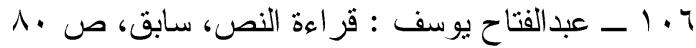

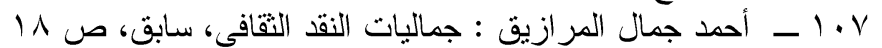

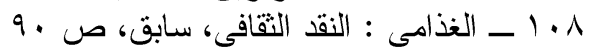

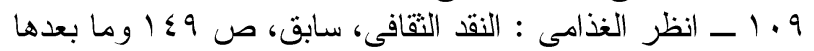

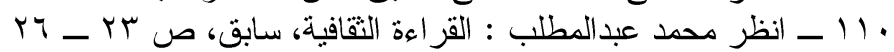

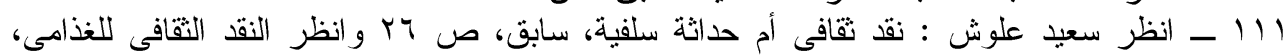
سابق، ص سا آ و ما بعدها

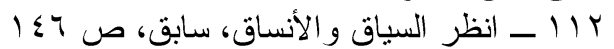

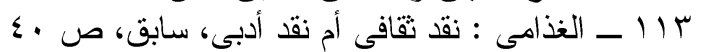

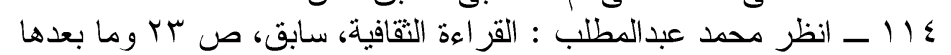
11 110

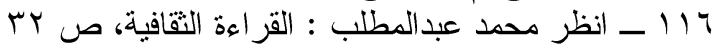
9 . IIV

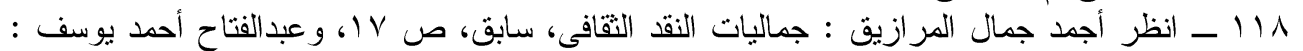

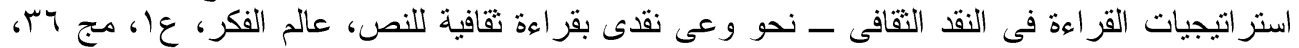

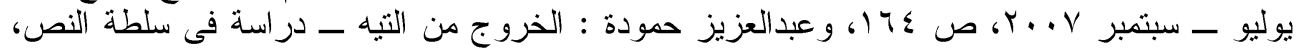

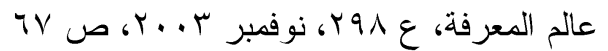

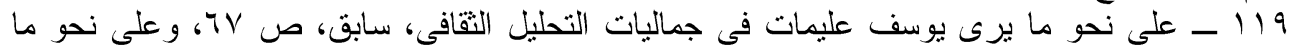

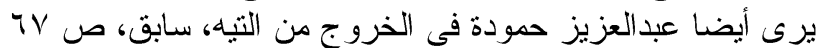

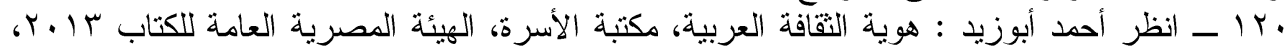

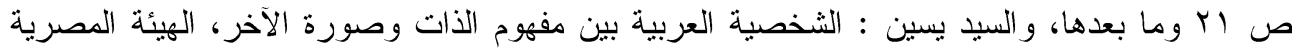

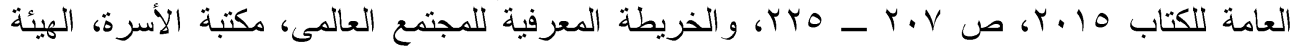

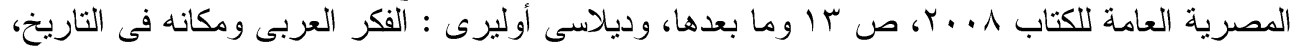

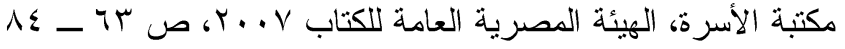

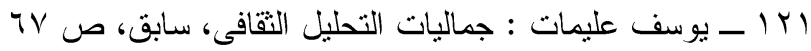




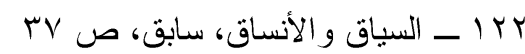

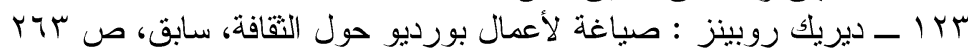

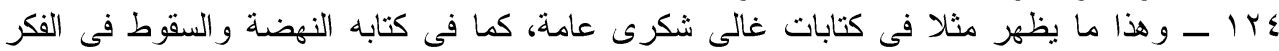

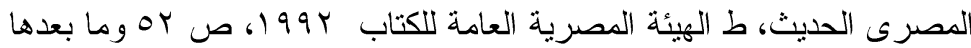

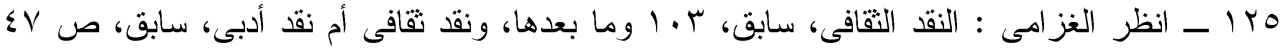

وما بعدها

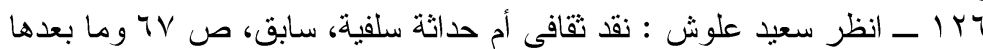

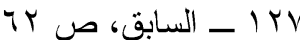

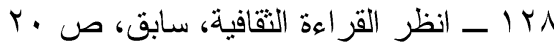

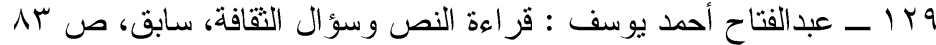

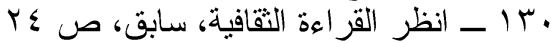

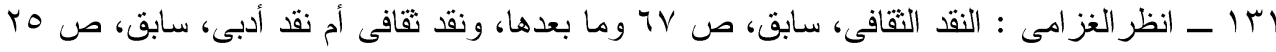

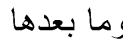

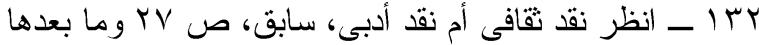

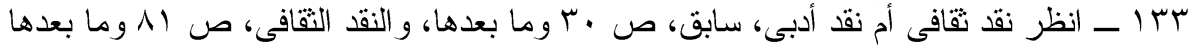

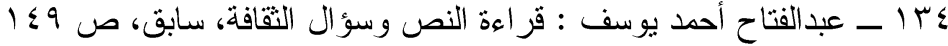

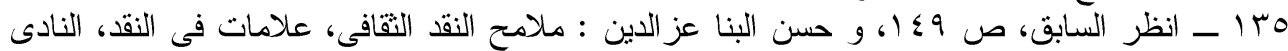

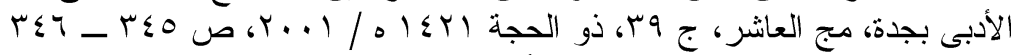

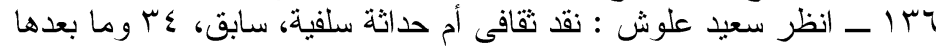

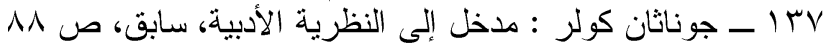

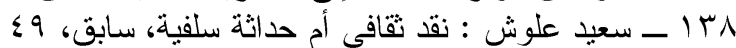

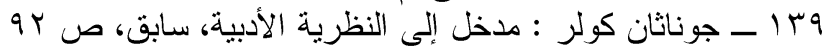

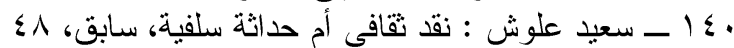

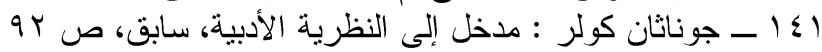

ج

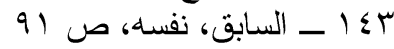

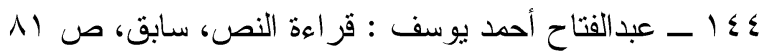

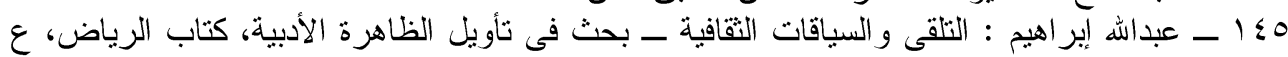

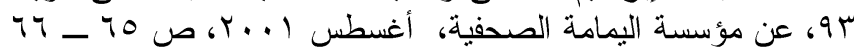

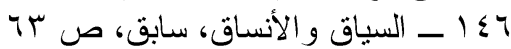

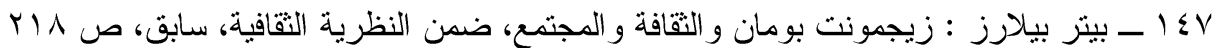

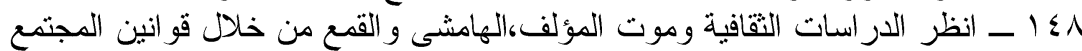

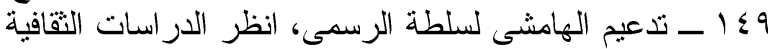

NV 10.

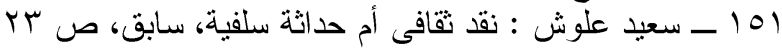

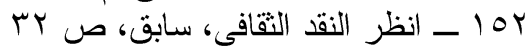

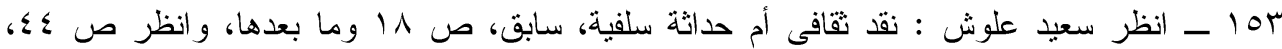

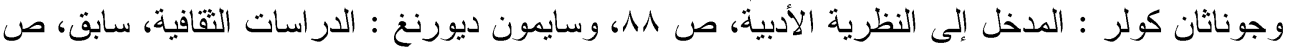

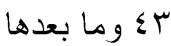

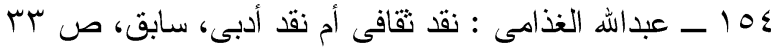

ا 100

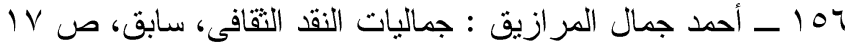

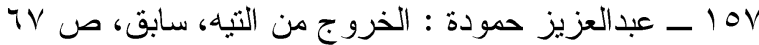

r 